\title{
A FLORISTIC INVENTORY AND REASSESSMENT OF THE FLORA OF SANIBEL ISLAND (LEE CO.), FLORIDA, U.S.A.
}

\author{
George J. Wilder \\ Naples Botanical Garden \\ 4820 Bayshore Drive \\ Naples, Florida 34112-7336, U.S.A. \\ gwilder@naplesgarden.org \\ Brenda Thomas \\ Florida Gulf Coast University \\ Department of Integrated Studies \\ 10501 FGCU Boulevard S \\ Fort Myers, Florida 33965, U.S.A. \\ bthomas@fgcu.edu
}

\author{
Jean M. McCollom \\ Natural Ecosystems \\ 985 Sanctuary Road \\ Naples, Florida 34120-4800, U.S.A. \\ jeanm@naples.net \\ Karen Relish \\ Naples Botanical Garden \\ 4820 Bayshore Drive \\ Naples, Florida 34112-7366, U.S.A. \\ krelish@naplesgarden.org
}

ABSTRACT

Sanibel Island (Lee Co., Florida) manifests eight main categories and 12 subcategories of habitats, and individual plant taxa occupy habitat(s) from one or more of those categories. Documented, presently as growing wild/apparently wild on Sanibel Island are individuals of 119 families, 397 genera, 611 species (including two hybrids), and 621 infrageneric taxa of vascular plants. Of the 621 infrageneric taxa, 420 $(67.6 \%)$ are native and $13(2.1 \%)$ are endemic to Florida. We interpret the Island's flora in terms of its history of severe natural and artificial disturbances.

\section{RESUMEN}

La Isla Sanibel (Lee Co., Florida) presenta ocho categorías principales y 12 subcategorías de hábitats, y cada taxon vegetal ocupa hábitat(s) de una o más de estas categorías. Actualmente, en la Isla Sanibel se documentan, creciendo silvestres/aparentemente silvestres, individuos de 119 familias, 397 géneros, 611 especies (incluyendo dos híbridos), y 621 taxa infragenéricos de plantas vasculares. De los 621 taxa infragenéricos, 420 (67.6\%) son nativos y 13 (2.1\%) son endémicos de Florida. Interpretamos la flora de la Isla en términos de las severas perturbaciones naturales and artificiales acaecidas.

\section{INTRODUCTION}

This is the eighth of a series of papers focused on the floras of south and central Florida (Wilder \& McCombs 2006; Wilder \& Roche 2009; Wilder \& Barry 2012; Wilder et al. 2014; Wilder \& Thomas 2016; Wilder \& McCollom 2018; Wilder et al. 2019). Herein, we describe the kinds of habitats on Sanibel Island and present the results of a floristic inventory of the infrageneric taxa of native and exotic vascular plants growing wild/apparently wild thereon.

Sanibel Island (hereafter, also called Sanibel or the Island) is a barrier island situated within the Gulf of

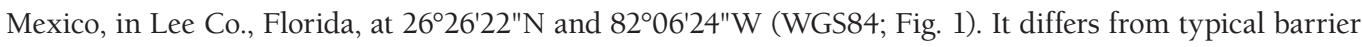
islands along the Florida peninsula, because its long axis extends perpendicular, rather than parallel, to the adjacent mainland (Lebuff \& Lechowicz 2013; Fig. 1). Northward, the Island borders San Carlos Bay and Pine Island Sound, southward, it abuts the Gulf of Mexico, and westward it faces, and is little separated from, Captiva Island. Sanibel Island is, approximately 12 miles long and less than 3 miles across at its widest point (Sanibel and Captiva Islands Chamber of Commerce 2019). It measures 11,000 acres (Clark 1976). Its maximum elevation is $13 \mathrm{ft}$ above mean sea level (Lebuff \& Lechowicz 2013). Discussed, in Appendix 3, is the origin of the name "Sanibel."

Approximately 6,000 years ago, unrecorded cataclysmic storms washed-up marine substrate, forming the Island. Later, Sanibel enlarged by the natural accretion of additional material (Lebuff \& Lechowicz 2013). 


\section{Historical sketch}

The Calusa Indians inhabited Sanibel and Captiva Islands from 500 AD to the late 1700s (LeBuff \& Lechowicz 2013). On Sanibel, their maximum population was approximately 200 individuals (Clark 1976). In south Florida, non-Indians annihilated and evicted the Calusa and by 1800 the Indians had virtually disappeared therefrom (Tebeau 1966, 1968).

Ponce de Leon, in 1513, was likely the first non-Indian explorer to observe and to moor his boat by Sanibel Island (Dormer 1987).

\section{Initial settlement by non-Indians}

Beginning in 1833 and for ca. another 50 years, Sanibel was settled in fits and starts, undergoing alternating periods of habitation and non-habitation. The Florida Peninsular Land Company, a group of New York investors, promoted settlement on Sanibel by platting a town (named Sanybel) at the eastern end of the Island. The Company sold the land to buyers who, in 1833, colonized the Island; however, by the early to mid-1830s the colonists had abandoned the Island, rendering Sanybel defunct. Although, additional people may have resided on the Island before that time, by 1844 Sanibel was again devoid of people (Dormer 1987; Repko 2010).

During the period of initial settlement, Dr. Benjamin Strobel—a colonist, physician, and amateur naturalist—toured the Island, observing a profuse flora including "morning glories," Gossypium hirsutum (Wild Cotton), and, apparently, Vachellia farnesiana ("Mimosa farnesiana"; Sweet Acacia) (Dormer 1987).

William Allen and his sons moved to the Island probably in 1869, establishing a castor bean plantation there. In 1870, Allen and one son were the sole residents of the Island. They left Sanibel possibly three years thereafter after a hurricane (Dormer 1987). Allen's efforts marked "the earliest serious agricultural attempt" on Sanibel (Lebuff \& Lechowicz 2013).

\section{Permanent settlement}

In 1884, a lighthouse was constructed at Point Ybel (the eastern tip of the Island; Fig. 1). A lighthouse keeper, his assistant, and possibly family members moved to Sanibel, becoming the Island's first permanent residents. Beginning in 1884, homesteaders immigrated to Sanibel, aided by the Homestead Act of 1862 and the Preemption Act of 1841. In 1888, the Acting Secretary of the Interior of the United States released the entire island for private ownership (aside from land associated with the lighthouse). Consequently, additional pioneers moved to Sanibel, first as a trickle and then in growing numbers. By May 1, 1889, 40 families lived on Sanibel, comprising a population of 100 (Dormer 1987).

\section{Farming}

Initially, farming was the chief motive for acquiring property on the Island (Lebuff \& Lechowicz 2013). Farmers cleared and cultivated the arable land (Cooley 1955). Bailey (2013) has recalled that at one time threequarters of the Island was farmed. Farming was concentrated within (but not limited to) the Island's eastern third and western quarter, largely along the long axis of the Island (a conclusion based on Map $\underline{\mathrm{C}}$ in Cooley 1955). Crops included avocados, cowpeas, eggplants, grapefruits, guavas, lemons, limes, okra, oranges, peppers, pumpkins, squashes, tomatoes, and watermelons (Cooley 1955; Dormer 1987; Repko 2010; Bailey 2013). In 1910, 1921, and 1926, however, three hurricanes struck Sanibel, flooding and salting the land and essentially ending farming as a lucrative business there (Veri \& Warner 1975; Dormer 1987; Revko 2010). After 1926, almost half of Sanibel's residents, including most of the farmers, left the Island (Clark 1976). The Great Depression ensued and between/including the 1930s and ca. the mid 1940s little growth transpired (Clark 1976; Bailey 2013).

\section{Explosive growth and development}

Beginning in the 1950s, people increasingly immigrated to Sanibel in response to its subtropical climate and natural beauty. In 1963, a three-mile-long causeway was completed between the Island and the mainland. The causeway, together with intense activity from developers and an increased availability of drinking water on the Island, placed Sanibel "under siege with construction" and induced an "onslaught of construction equipment and vehicular traffic" (Anholt 2004). In 1974, Sanibel's residents voted to incorporate the Island as a city named 


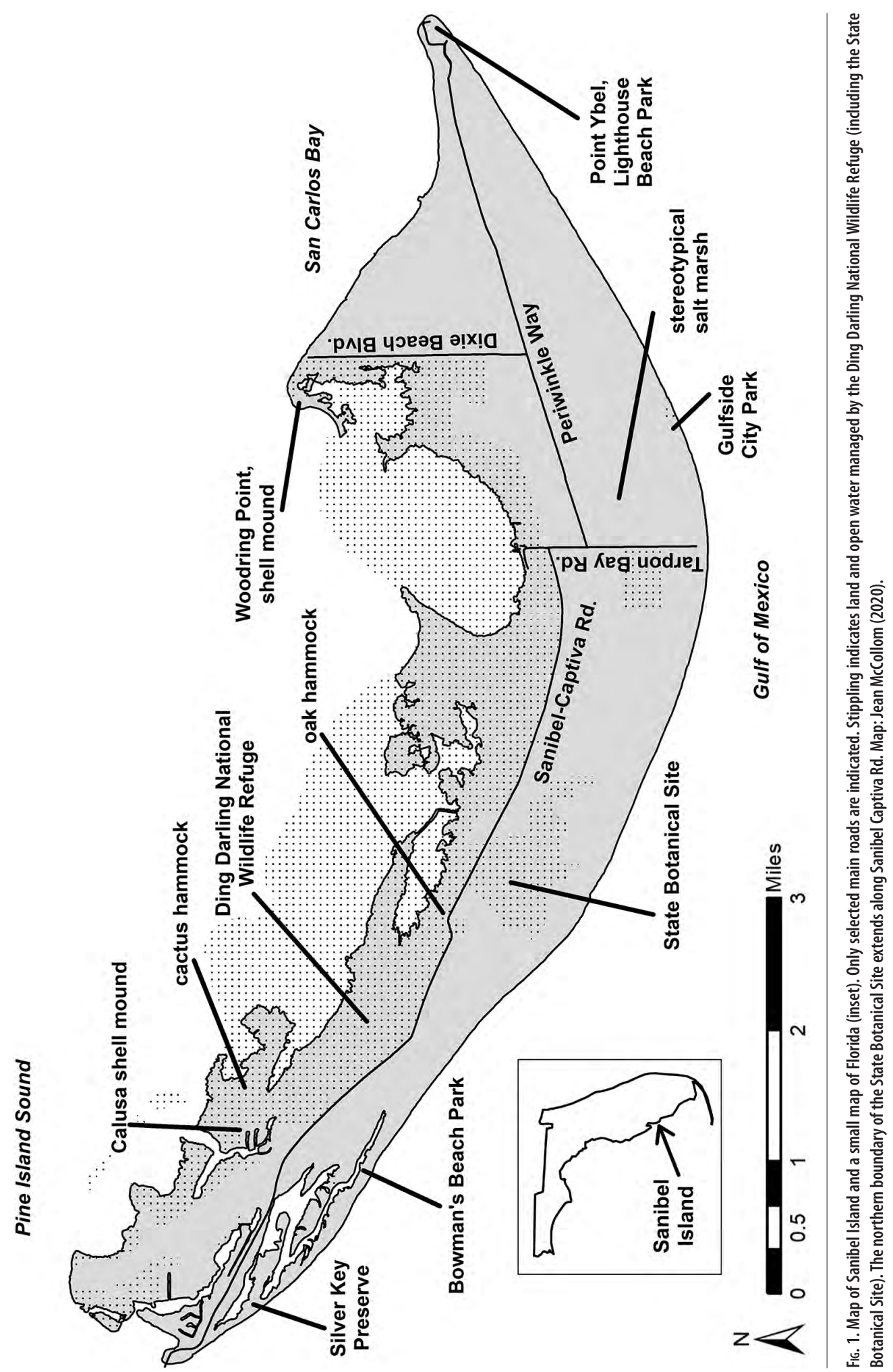


Sanibel. The new City government issued a moratorium on new building permits and Sanibel acquired greater control over its future (Clark 1976; Dormer 1987; Anholt 2004).

Following incorporation, John Clark (of The Conservation Foundation) prepared a report about the natural systems of Sanibel (Clark 1976). In 1976, the City utilized that report to establish a "Comprehensive Land Use Plan and Development Code" for the Island. Thereby, Sanibel based its land development code on the preservation of natural resources (Anholt 2004).

\section{Environmental disturbances}

Artificial and natural disturbances have severely impacted the Island's flora. During initial settlement, "the interior of the island was an extensive grassy plain, so level that one could see for miles with only a few palmettos intervening" (Dormer 1987). In sharp contrast, today much of the Island's preserved land (not including mangrove habitat) is intermittently or densely wooded and/or variously disturbed.

Major artificial disturbances to the Island have included: 1. farming; 2. the introduction and rapid spread of exotic plant species; 3. fire suppression; 4. the installation of roads, subdivisions, commercial centers, and golf courses; $\mathbf{5}$. the creation of numerous ditches, canals, weirs (water control structures), and borrow pits; 6 . significant stabilization of the water table and elimination of natural seasonal hydrologic fluctuations; 7 . the intrusion of saltwater into freshwater, because of overly deep excavation; and $\mathbf{8}$. other kinds of degradation of water quality.

Anholt (2004) commented as follows. "Mosquito control ditching and channelization, which occurred in the 1960s, altered the island's interior wetland system by effectively lowering the wet season water table and altering the habitat. All of these alterations ... had a cumulative impact. Wetlands and prairie-oriented wildlife diminished as grasslands changed to woody shrub land. When exotic plants took over, indigenous vegetation and wildlife generally suffered. The non-natives ... quickly spread."

Invasive exotic plants infested Sanibel, and for years the Sanibel-Captiva Conservation Foundation (SCCF), the Ding Darling National Wildlife Refuge (DDNWR), the City of Sanibel, and private individuals have removed them from widespread areas of the Island. Targeted, especially, were Casuarina sp./spp. (Australian Pine), Melaleuca quinquenervia (Punktree), and Schinus terebinthifolia (Brazilian pepper). As well, the DDNWR listed 19 additional species to target for treatment in their Comprehensive Plan, the City of Sanibel Land Development Code prohibited the planting/transplanting of eight species of invasive exotics, and SCCF treated species listed by the City plus six additional exotic species (Lechowicz 2020; City of Sanibel 2021a). Those efforts/policies facilitated the elimination of Melaleuca quinquenervia from the DDNWR by Nov 2004, and today the species is near absent from Sanibel (DDNRC 2010). We observed solely one individual of M. quinquenervia (at the West Sanibel River Preserve [SCCF]), which SCCF staff members subsequently destroyed. We commend the agencies and private citizens which treat(ed) the invasive plant species. The near elimination of M. quinquenervia reflects their intensive work.

Anholt (2004) reviewed in detail how different agencies/governmental entities labored to remedy additional disturbances. Especially important, was the construction of two weirs at Tarpon Bay Rd. and Beach Rd., which raised water levels on the Island year-round, thereby $\mathbf{1}$. stabilizing water levels in wetlands and $\mathbf{2}$. helping to prevent salinization of the groundwater aquifer below the Island. The weirs, however, had negative repercussions. By impeding natural recession of water levels during the dry season they made the prescribed burning of wetlands difficult and facilitated the invasive spread of Conocarpus erectus (Buttonwood) within the Island (Chris Lechowicz [Director-Wildlife Habitat Management, Sanibel-Captiva Conservation Foundation], pers. comm. to Jean McCollom, 25 Feb 2020).

Hurricanes and tidal surges rank high among the natural disturbances to the Island. Since 1873, twenty hurricanes have passed within 75 miles of Sanibel (City of Sanibel 2021b). As stated, farming on Sanibel was ended by salt water intrusion from hurricane tides that covered the Island in 1910, 1921, and 1926 (Veri \& Warner 1975). Surges that did not overtop the whole Island occurred during severe hurricanes in 1873, 1894, 1935, 1944, 1947, 1960 (Hurricane Donna), 2004 (Hurricane Charley), and 2005 (Hurricane Wilma) (Clark 
1976; Attaway 1999; Barnes 2007; City of Sanibel 2021b). Too, Clark (1976) stated that the tide level (13.5 feet) predicted for Sanibel during a "100-year storm" would inundate the entire Island.

The frequency and severity of hurricanes during the $19^{\text {th }}$ and $20^{\text {th }}$ centuries suggest that hurricanes have impacted Sanibel for millennia. Probably, on numerous occasions throughout the Island's history storm surges have inundated and cleared/partly cleared the Island of weakly-rooted and/or salt-intolerant plant species. If so, the Island's flora has had a cyclical past involving alternating episodes of species-elimination and periods of recovery. During the recovery periods, plants presumably migrated to Sanibel, allowing for replacement/partial replacement of extirpated species and for the establishment of new species.

\section{Land preservation}

Individuals, private organizations, and governmental entities have acted repeatedly to conserve land on Sanibel. Over two-thirds of the Island is now set aside through federal or municipal-government or privatefoundation ownership (Sanibel \& Captiva Islands Chamber of Commerce 2019). The Sanibel-Captiva Conservation Foundation, which was incorporated in 1967, has led in the conservation efforts.

Based on ownership and management, Sanibel's conserved lands compose four main categories: 1. properties owned/managed by SCCF; 2 . properties owned/managed by DDNWR (excluding the State Botanical Site); 3. the State Botanical Site (a matrix of properties having multiple owners but managed by the DDNWR); and 4. properties owned/managed by the City of Sanibel. Prominent, among the City's properties are Bowman's Beach Park (an area managed by the City but owned by Lee County), Gulfside City Park, Lighthouse Beach Park, and Silver Key Preserve (Fig. 1).

The DDNWR, established in 1967, is administered by the U.S. Fish and Wildlife Service. It encompasses extensive land north of Sanibel-Captiva Rd. plus additional holdings situated elsewhere on the Island (e.g., the Bailey Tract). Also, we attribute to the DDNWR a 67 -acre property that extends westward from the eastern terminus of Wulfert Rd.; the DDNWR does not own that property but will manage it in the future. The name "Ding Darling National Wildlife Refuge" honors Jay N. ("Ding") Darling, who was a Pulitzer Prize-winning cartoonist and a pre-eminent conservationist on the Island. The State Botanical Site was established in ca. 1987 (Anholt 2004).

\section{Climate}

Sanibel is located within the subtropics and manifests a well-defined rainy season and dry season. During Jun through Sep (the four months of the rainy season) normal monthly rainfall varies from 8.3 to $10.1 \mathrm{in}$, whereas, during Oct through May (the eight months of the dry season) the normal rainfall ranges from 1.7 to $2.9 \mathrm{in}$. Normal annual rainfall is $55.9 \mathrm{in}$. The highest average monthly high temperatures $\left(91-92^{\circ} \mathrm{F}\right)$ and the highest average monthly low temperatures $\left(74-75^{\circ} \mathrm{F}\right)$ coincide with the four months of the rainy season. The lowest average monthly high temperatures $\left(75-89^{\circ} \mathrm{F}\right)$ and the lowest average monthly low temperatures $\left(54-69^{\circ} \mathrm{F}\right)$ characterize the remaining months (Sanibel \& Captiva Islands Chamber of Commerce 2019). Winter-freezes are infrequent, with a temperature-low of $26^{\circ} \mathrm{F}$ (LeBuff and Lechowicz 2013); no freezes have occurred from May 2014 through mid-Apr 2021 (unpublished data from a DDNWR weather station [Jeremy Conrad, Senior Wildlife Biologist at DDNWR, pers. comm. to George Wilder, 22 Apr 2021]).

Along Florida's western coast the $54^{\circ} \mathrm{F}$ isotherm (the line where the average daily minimum temperature for January is $54^{\circ} \mathrm{F}$ ) extends northward to Sanibel Island. That isotherm "... represents a probability that the harsh, cold conditions lethal to many tropical plants will not occur south or seaward of it ..." (Lodge 2010). Sanibel's proximity to the $54^{\circ} \mathrm{F}$ isotherm helps explain the presence/abundance of certain tropical species, thereon.

As discussed above, hurricanes pose an ever-present danger to Sanibel during the warmer months.

\section{Topography and soils}

The Island manifests seven main topographic zones. Progressing from south to north, they are the Gulf beach, the Gulf beach ridge, the interior wetland basin, the mid-Island ridge, mangroves, tidal flats, and the Bay 
beach. We discuss those zones only briefly, but Clark (1976) and Lebuff and Lechowicz (2013) have provided more detailed accounts, thereof.

The Gulf beach extends for the length of the Island, whereas the Bay beach is shorter and narrower. The Gulf beach ridge manifests coastal strand vegetation.

Midway along the length of the Island, the mid-Island ridge bifurcates into two branches which extend westward, i.e., a northern branch and a southern branch. The northern branch manifests mesic oak hammock (discussed below; Fig. 1). The eastern portion of Sanibel-Captiva Rd. extends along the mid-Island ridge, but follows the southern branch where the ridge bifurcates (Fig. 1). Aside from the mid-Island ridge and the Gulf beach ridge, the Island—especially within the interior wetland basin—exhibits numerous minor, often parallel, alternating ridges and swales (Cooley 1955; Clark 1976; Lebuff \& Lechowicz 2013).

The interior wetland basin is a depression bordered by the Gulf beach ridge and the mid-Island ridge. Marshes are frequent in much of the interior wetland basin and in certain areas north of Sanibel-Captiva Rd. As well, the Sanibel Slough (also called the Sanibel River), a watercourse of natural origin, extends from ca. west to east through the basin; it currently has weirs at both outlets.

Henderson (1984) indicated two general soil types for the Island: Wulfert-Kesson-Captiva and CanaveralCaptiva-Kesson. Based on Henderson's (1984) "General Soil Map," the two types underlie, respectively, the mangrove zone (and possibly also the tidal flats) and all remaining zones situated southward, thereof.

\section{Previous botanical research on Sanibel Island}

Cooley (1955) published the first flora of Sanibel, listing 309 infrageneric taxa of vascular plants plus the alga Chara zeylanica for the Island. Thereafter, for nearly 20 years William C. Brumbach collected vouchers from Sanibel, Captiva Island, and the Florida Keys, assembling three herbarium cabinets of specimens at SCCF and depositing additional specimens at FTG, UF, USF, and 15 other herbaria (Wunderlin \& Hansen 1985; SERNEC 2020; Virtual Herbarium 2021; Wunderlin et al. 2020, pers. obs.). Next, Wunderlin and Hansen (1985) described the vascular floras of Sanibel and Captiva Islands together, listing 603 species for both islands collectively; however, they did not specify which, or how many, species were solely from Sanibel. Wunderlin and Hansen (1985) based their description partly on Brumbach's collections. Subsequently, Herwitz and Wunderlin (1990) reanalyzed Wunderlin and Hansen's (1985) data, listing 432 native species from Sanibel.

Investigators compiled three additional inventories of vascular plants that were limited to parts of the Island. 1. Wunderlin et al. (1980) investigated the flora of the DDNWR, reporting 254 infrageneric taxa there. 2. Bradley (2002) compiled a group of seven unpublished plant lists for selected preserves managed by SCCF, particularly Frannie's Preserve and the Johnston Tract. Each list enumerated the species of a separate habitat. 3. Most recently, Stalter and Lamont (2021) reinvestigated the flora of the DDNWR, listing 319 species therefrom.

Previous investigators recognized types of habitats and plant communities on Sanibel, but they differed considerably from each other as to what types were present. Cooley (1955) recognized seven main habitattypes, viz., coastal shell ridge, grasslands and savannas, mangrove swamps, mixed woods, old fields, palmetto jungles, and Spartina marshes. Wunderlin et al. (1980) identified seven main community types within the DDNWR (which, to an extent, Stalter and Lamont [2021] also recognized), viz., coastal dune, coastal dry hammock, freshwater marsh, mangrove, ruderal land, salt marsh, and tropical hammock.

Previous workers collected extensively on Sanibel. Listed below, are the numbers of vouchers therefrom, housed at selected herbaria: 1,461 (USF), 1,104 (SWF), 335 (UF), 238 (NY), 222 (NCU), 215 (FTG), and 535 (SERNEC [a consortium of herbaria, excluding for present purposes UF, NCU, NY, UF, USF]). Aside from Brumbach, prolific collectors at Sanibel included K.A. Bradley, S.H. Brown, J.A. Churchill, G.R. Cooley, D.S. Correll, B.F. Hansen, W.W. Holland, O.K. Lakela, E. Lamont, S.W. Leonard, J. Matthews, A.E. Radford, R. Stalter, S.M. Tracy, and R.P. Wunderlin (SERNEC 2020; Virtual Herbarium 2021; Wunderlin et al. 2020). 


\section{Reasons for undertaking the present investigation}

We undertook this study for three main reasons. 1. We wished to augment knowledge of Sanibel's habitats and to specify, for each species inventoried, which habitat(s) it occupied. We also desired to determine which species inhabited each of the five general areas of the Island (below). 2. We wished to re-inventory the flora of the Island, which had last been investigated in its entirety 34 years earlier (Wunderlin \& Hansen 1985). Too, we desired to evaluate our findings in terms of Cooley's (1955) account, which we construe as a baseline for Sanibel's flora. 3. We wished to document with herbarium specimens or photographs all species that we encountered.

\section{METHODS AND TERMINOLOGY}

We undertook fieldwork for this study from/including 15 Jun 2019 through 5 Apr 2021. During that time, we undertook 163 field trips to the Island, including multiple visits for each month of the year. We inventoried the native and exotic species growing wild on the Island, and for natural areas/preserves (excluding flower beds and shrub beds, therein) we also inventoried the planted/possibly planted species (see below). For all flower beds/shrub beds, we inventoried solely non-planted individuals, particularly, weeds.

We vouchered all infrageneric taxa with specimens or photographs and we deposited all voucher materials in the Herbarium of Southwestern Florida (SWF; Appendix 1). Mostly, we prepared dried herbarium specimens; however, we fixed material of Lemna aequinoctialis in an aqueous solution of ethanol (50\%), formaldehyde $(5 \%)$, and either acetic acid (5\%) or propionic acid (5\%). The fixed material was rinsed in water and was then stored permanently in an aqueous solution of glycerin (5\%) and ethanol (50\%).

We documented the following species, solely, with numbered photographs rather than with actual specimens: Adonidia merrillii, Celosia nitida, Celtis pallida, Coccothrinax argentata, Dypsis lutescens, Harrisia aboriginum, Jacquemontia reclinata, Leucothrinax morrisii, Livistona chinensis, Musa sp., Pandanus sp., Pseudophoenix sargentii, Ravenala madagascariensis, Roystonea regia, Serenoa repens forma glauca, Thrinax radiata, Tillandsia fasciculata, Tillandsia utriculata, and Washingtonia robusta.

Mostly, present nomenclature follows Wunderlin et al. (2020; as listed on 16 Oct 2020); however, Appendix 1 (footnote 1) specifies nomenclatural differences between that source and the present paper. We define infrageneric taxa as including only species, subspecies, varieties, formas, and hybrids. In Appendix 1, certain species (e.g., Eragrostis ciliaris) are listed more than once, as different varieties or formas. For each such species, following its initial listing in Appendix 1, each additional listing is said to represent an additional infrageneric taxon.

We also follow Wunderlin et al.'s (2020; as listed on 16 Oct 2020) assessments as to whether individual species are native, endemic, or exotic. For various species, those assessments differ from those of Wunderlin and Hansen (2011). Accordingly, for those species the assessments presented herein differ from those presented in earlier papers of the present series.

For descriptive purposes, we divide Sanibel into five general areas (Appendix 1, vertical column at right): 1. the State Botanical Site, 2. Bowman's Beach Park, 3. properties managed/to be managed by the DDNWR (excluding the State Botanical Site), 4. properties managed by SCCF, and 5. all other parts of the Island. Included, in the last category are private holdings and all City-managed properties (excluding Bowman's Beach Park).

\section{A problem of introduced plants}

In the past, people introduced plants into the preserves/natural areas of the Island. They did so for general restorative purposes, to remedy habitat damage from hurricanes, and for beautification. Abundant plants were introduced at Bowman's Beach Park, the Bob Wigley Preserve (SCCF), the Periwinkle Preserve (SCCF), and elsewhere. During current research it often proved difficult/impossible to distinguish the planted from the non-planted individuals. 
Apparent former homesites were likewise problematical for distinguishing planted from non-planted individuals. For example, one site within the Wulfert Gopher Tortoise Preserve (managed by SCCF) manifested diverse species which were clearly outside of their natural ranges in Florida or elsewhere (e.g., Gymnanthes lucida, Malpighia emarginata). Another former homesite (managed by the City of Sanibel and located along Island Inn Rd.) exhibited many exotic species of Arecaceae (Appendix 1). As well, the DDNWR contained one, possibly two, apparent former homesite(s) which manifested Pinus elliottii-a species native to Florida, but which we judge to be represented on the Island today solely by introduced individuals.

We posed three questions to help evaluate the questionable individuals. 1. Did an individual belong to a species which—on the Island—existed outside of its known natural range? 2. Did it grow in a restored area? 3. Was it restricted spatially to locations (e.g., at/near trail sides) where it would likely have been planted? Also, staff members of DDNWR and SCCF, and other individuals, informed us that plants had been introduced into certain areas.

We have concluded that the species which people planted/apparently planted within the Island's preserves/natural areas comprise five categories. 1. Species which we interpret as also being native to, and as growing naturally on, the Island (e.g., Casasia clusiifolia, Quadrella jamaicensis, Spartina bakeri). 2. Species which we interpret as non-native to the Island, but as native to mainland areas adjacent thereto; those species have, apparently, not escaped on the Island (e.g., Taxodium distichum, Zamia pumila). 3. Species which are native to Florida, but which—on the Island-grow well outside of their natural ranges within the State; we recognized no escaped individuals of those species (e.g., Bourreria succulenta, Chrysophyllum oliviforme, Guaiacum officinale, Heliotropium gnaphalodes, Jacquemontia reclinata, Krugiodendron ferreum, Leucothrinax morrisii, Myrcia neopallens, Pithecellobium keyense, Pseudophoenix sargentii, Thrinax radiata, Vachellia choriophylla). 4. Species conforming to category no. $\underline{3}$, above, but which also manifest escaped individual(s) (an assessment based in some cases on our discovery of seedlings/saplings, thereof [e.g., Canella winterana, Citharexylum spinosum, Gymnanthes lucida, Lysiloma latisiliquum, Simarouba glauca, Swietenia mahagoni]). 5. Species exotic to Florida (e.g., Antigonon leptopus, Delonix regia, Jasminum sambac, Malpighia emarginata).

In Appendix 1, we apply the phrase "Apparently, planted material only" to species which are native to Florida or elsewhere, but which we deem to have been solely planted on and to be non-native to, and which have not been found to be reproducing on the Island.

We began this study by inventorying solely species which we considered native, naturalized, or escaped on the Island. Over time, we realized that-for preserves and natural areas-our sole path to an acceptable inventory was to list all species present, including those represented by planted, possibly planted, and nonplanted individuals (but excluding those planted in flower beds, shrub beds, and lawns).

RESULTS AND DISCUSSION

\section{Habitats}

We recognize eight main kinds of habitats on the Island: hammock, shell mound, beach habitat, dune habitat, coastal strand, marsh, mangrove habitat, and ruderal land (Appendix 1). We also group beach habitat, dune habitat, and coastal strand together under the heading of "coastal habitats."

\section{Hammock}

On the Island, hammock is forested, generally mesic habitat which characteristically exhibits a dense overstory and a dense understory of trees and shrubs. Typically, dicotyledonous species compose both stories, but sometimes the sole trees present within a portion of hammock are Sabal palmetto. Hammock may intergrade with, and be difficult to distinguish from, coastal strand. It varies from high-quality to disturbed. We recognize three subcategories, thereof.

Typical hammock.-We noted high-quality, typical hammock in the Mitchell Tract, the Wulfert Gopher Tortoise Preserve, and certain other SCCF properties. Prominent woody species, therein, included Bursera simaruba, Chiococca alba, Chrysobalanus icaco, Eugenia axillaris, Ficus aurea, Myrsine cubana, Psychotria nervosa, and Sabal palmetto. Depending on the hammock studied, herbaceous ground cover varied from virtually 
absent to evident. In one hammock (SCCF property) Nephrolepis brownii, Nephrolepis cordifolia, and Phlebodium aureum were the only herbaceous species present. At the State Botanical Site, in one large portion of disturbed hammock (where trees of Sabal palmetto with fire-charred trunks were the sole mature, woody plants present) we observed dense herbaceous groundcover; prominent, therein were Blechnum serrulatum, Chromolaena odorata, Eupatorium capillifolium, and Pluchea caroliniana.

Oak hammock.-The Island exhibits one such hammock (Fig. 1). Located within the DDNWR, it is unique, being dominated largely by massive trees of Quercus virginiana (Live Oak), some with conspicuous, low-hanging branches. The hammock is exceptional, because of its large area, maturity, luxuriance, and species diversity. Prominent, in addition to the oaks are Bursera simaruba, Eugenia axillaris, Myrsine cubana, Psychotria nervosa, Randia aculeata, Sideroxylon foetidissimum, and Sabal palmetto. Pleopeltis michauxiana, which is uncommon on the Island overall, is abundant within the hammock, is the most pervasive species of epiphytes there, and festoons some of the oaks. Herbaceous groundcover is essentially absent, aside from widely scattered patches of Telmatoblechnum serrulatum.

Cactus hammock.-A small amount, thereof, is situated within the DDNWR north of Sanibel-Captiva Rd., where it is possibly intermingled with shell mound (Figs. 1, 2). Cactus hammock differs from the two other types of hammocks, by manifesting dense aggregates of Acanthocereus tetragonus (Barbed-Wire Cactus; Cactaceae). Also, common therein are Ardisia escallonioides, Bursera simaruba, Erythrina herbacea, Eugenia axillaris, Eugenia foetida, Petiveria alliacea, Pithecellobium unguis-cati, Quadrella jamaicensis, Selenicereus undatus, Sideroxylon foetidissimum, and Zanthoxylum fagara. Wilder and Barry (2012) reported comparable cactus habitat on Dismal Key and Fakahatchee Island (two islands/shell mounds situated within the Ten Thousand Islands region of the Gulf of Mexico).

\section{Shell mounds}

Herein, we define "shell mound" broadly as any manmade deposit of sea shells. We investigated two shell mounds. 1. A mound called the Calusa shell mound by US Fish and Wildlife Service (and also known as the Wightman Site [Dormer 1987; Anholt 2004]). It is located within the DDNWR near the western terminus of Wildlife Drive (Fig. 1). The Calusa Indians created it in pre-Columbian time (William H. Marquardt [Curator Emeritus, Florida Museum of Natural History], pers. comm. to George Wilder, 22 Nov 2020). It is forest-covered and overlain by topsoil. Much of the forest resembles hammock, but we do not classify it as such, because of the underlying artificial shell substrate. Remaining forest is mangrove vegetation. 2. A very disturbed mound of unknown origin, created either by Indians or non-Indians (perhaps, as fill). This mound is situated at Woodring Point (along the northern shore of the Island), on land managed by the DDNWR (Fig. 1). The shell substrate lacks topsoil and, in part, tree cover.

\section{Coastal habitats}

As stated, these include beach habitat, dune habitat, and coastal strand. The habitats, collectively, line the southern shore of the Island and are characteristically encountered in the order listed, progressing landward from the Gulf of Mexico.

However, atypical sequences of habitats occur. For example, coastal strand may be absent or poorly developed, apparently because of erosion, hurricane damage, or development. Too, dune habitat managed by the DDNWR and situated eastward of Gulfside City Park is bisected by a narrow, linear depression parallel to the Gulf shore. That depression contains mangrove habitat which separates a seaward sector from a landward sector of the dune habitat. Also, by Silver Key Preserve, progressing landward from the Gulf of Mexico one encounters, sequentially, beach habitat, mangrove habitat, and coastal strand

Habitat boundaries are discrete or ill defined. Beach habitat and dune habitat may intergrade, as may dune habitat and coastal strand.

Beach habitat.-The beach is generally flat or sloped downward toward the Gulf of Mexico. In places it lacks vegetation completely. Elsewhere, scattered vegetation occurs, particularly on the landward portion of the beach (Fig. 3). Herbaceous species and depauperate woody plants predominate. Prominent, are Helianthus debilis subsp. debilis, Ipomoea pes-caprae, Iva imbricata, Oenothera humifusa, Scaevola plumieri, and Sesuvium 


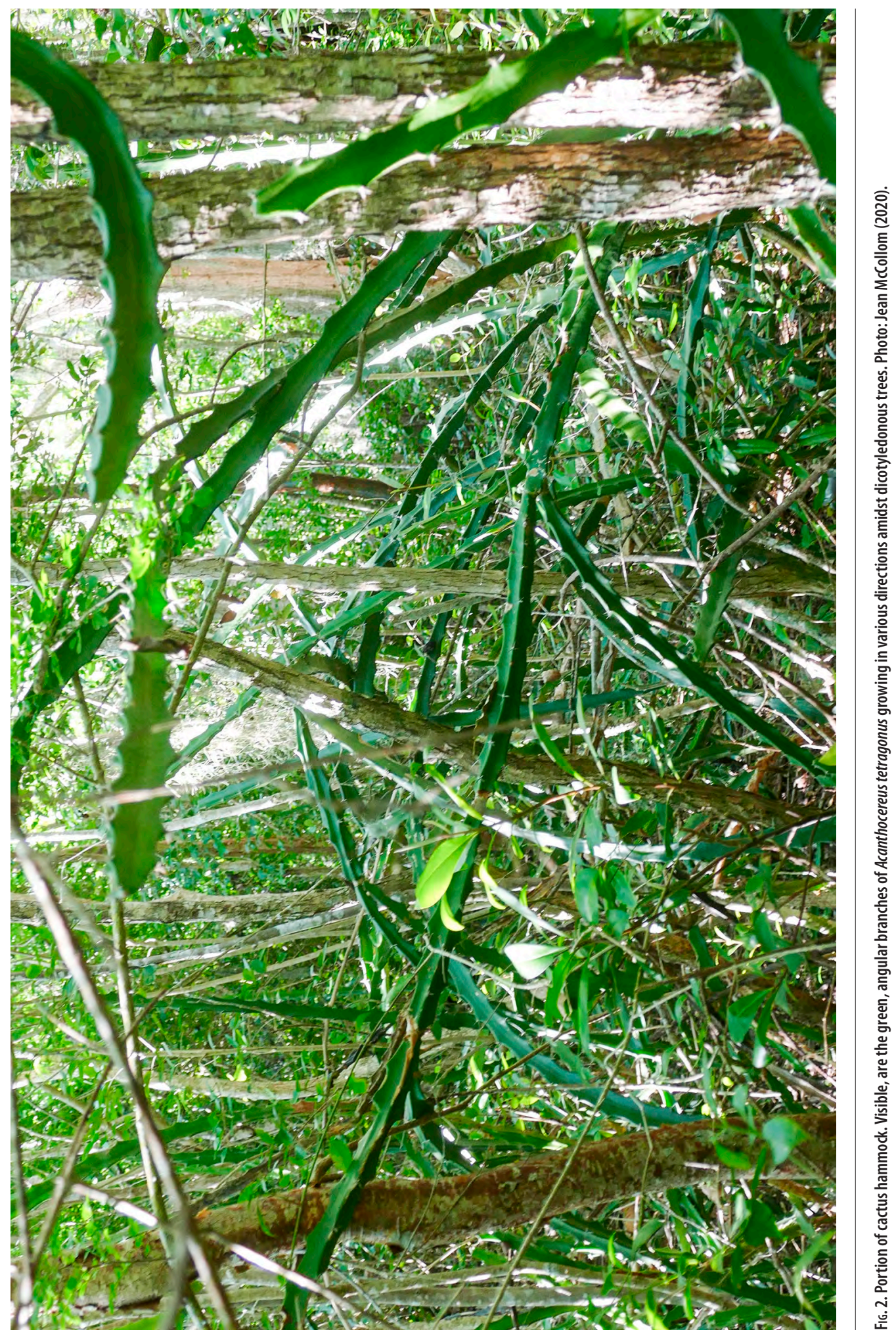




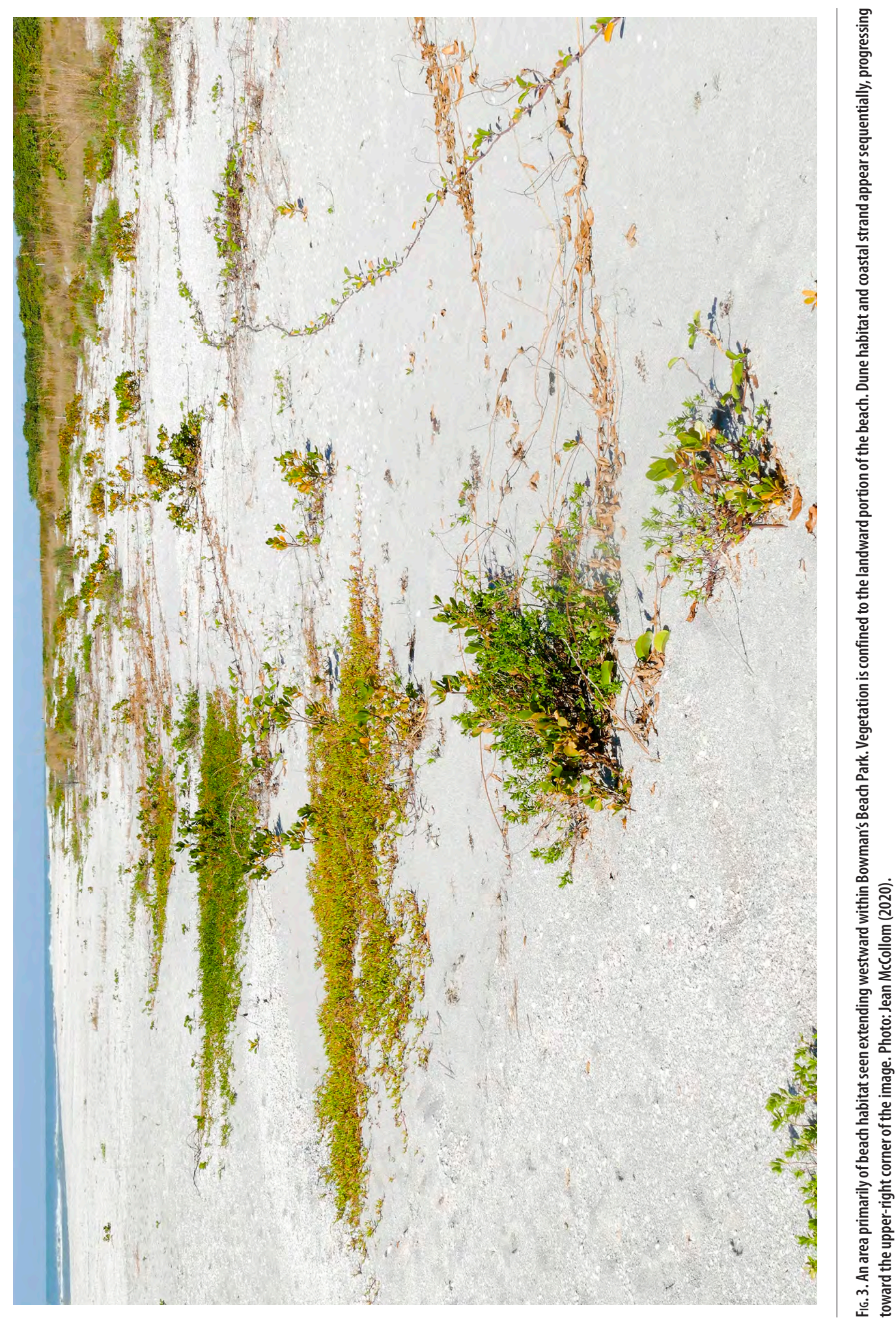


portulacastrum. The beach plants are either discrete, compose dense, monospecific clumps/clones (e.g., of Oenothera humifusa and Sesuvium portulacastrum), manifest runners (Sporobolus virginicus), or grow as branched, prostrate vines (Ipomoea pes-caprae). Along the northern shore of the Island, portions of beach exposed solely at low tide manifest seagrass species rooted in situ, viz., Syringodium filiforme and Thallassia testudinum. High-quality beach habitat and dune habitat coexist at Bowman's Beach Park.

Dune habitat.-Here sand composes low, insolated hills and valleys and varies from a little higher than, to a little lower than, the landward portion of the beach (Fig. 4). Vegetation is more concentrated than on the beach. Prominent, are Andropogon glomeratus var. pumilus, Andropogon virginicus, Canavalia rosea, Caesalpinea bonduc, Coccoloba uvifera, Cyperus ovatus, Dalbergia ecastaphyllum, Helianthus debilis subsp. debilis, Heliotropium polyphyllum, Oenothera humifusa, Oenothera simulans, Physalis angustifolia, Scaevola plumieri, Triplasis purpurea, Sporobolus virginicus, Suriana maritima, and Uniola paniculata.

Coastal strand.- - Here the substrate may be higher than, at ca. the same level as, and/or be sloped downward in the landward direction from, the adjoining dune habitat. Coastal strand manifests concentrated trees and shrubs but varies in quality. Silver Key Preserve exhibits the most pristine coastal strand on the Island. Common, therein are Bursera simaruba, Chiococca alba, Coccoloba uvifera, Conocarpus erectus, Forestiera segregata, Jacquinia keyensis, Randia aculeata, and Toxicodendron radicans. At Bowman's Beach Park the coastal strand includes extensive disturbed areas. Elsewhere, coastal strand which borders certain housing lots is kept artificially pruned and exhibits fewer species.

\section{Marsh}

This is open wetland which generally lacks tall trees. Marshes abound on the Island, and we recognize five subcategories, thereof.

Spartina marsh.-Spartina bakeri (Cordgrass) is dominant (judging by cover rather than height). This is the most frequent kind of marsh on the Island. Prominent examples occur within the State Botanical Site (especially south of the Sanibel Slough), the DDNWR, and the Erik Lindblad Preserve (SCCF). Within a Spartina marsh the Spartina plants grow either alone or intermixed with additional species, e.g., Acrostichum danaeifolium, Baccharis halimifolia, Borrichia frutescens, Cladium jamaicense, Conocarpus erectus, Eupatorium serotinum, Ipomoea sagittata, Mikania scandens, Myrica cerifera, Sabal palmetto, Salix caroliniana, Sesuvium portulacastrum, and Typha domingensis. Occasionally, in place of Spartina a small area of Spartina marsh exhibits a dense aggregate of A. danaeifolium or T. domingensis. On the Island, S. bakeri-aside from composing marshes—also abuts open water and inhabits drier ruderal land.

Sesuvium marsh.-This exhibits a mat of Sesuvium portulacastrum (Seapurslane). Interspersed, therein are Acrostichum danaeifolium, Baccharis halimifolia, Cladium jamaicense, Fimbristylis spadicea, Sabal palmetto, Solidago sempervirens, and other species. We observed Sesuvium marshes in the northern, and especially in the southern sectors of the State Botanical Site. One Sesuvium marsh bordered, and was sharply demarcated from, a Spartina marsh.

Marsh derived from mangrove forest.-This exhibits abundant skeletons of long-dead, sometimes toppled, mangrove trees, although the cause of death of the trees is unknown. Numerous species and individuals of Tillandsia inhabit the tree skeletons; thus, this kind of marsh is richer in bromeliads than are all four other kinds of marsh. Space within/between the tree skeletons freely transmits sunlight to the substrate, allowing for a dense herbaceous groundcover. We observed three examples of such marshes, all within the DDNWR. 1. A linear marsh located well north of Sanibel-Captiva Rd. (Fig. 5 [the marsh was photographed in winter when it manifested reduced groundcover]). There the tree-skeletons manifested all nine Tillandsia species reported herein (Appendix 1). Salicornia ambigua was the prevailing groundcover, but Batis maritima and Borrichia frutescens were prominent, as well. 2. A marsh situated southwest of the northern terminus of Tarpon Bay Rd. Here the groundcover included comparable amounts of S. ambigua and B. maritima. 3. A marsh bordering the northern side of Sanibel Captiva Rd., northeast of the DDNWR tram parking lot. This marsh was unique in having many living mangrove trees intermingled with the dead ones. The herbaceous ground cover was primarily Sesuvium portulacastrum, but also included patches of S. ambigua. 


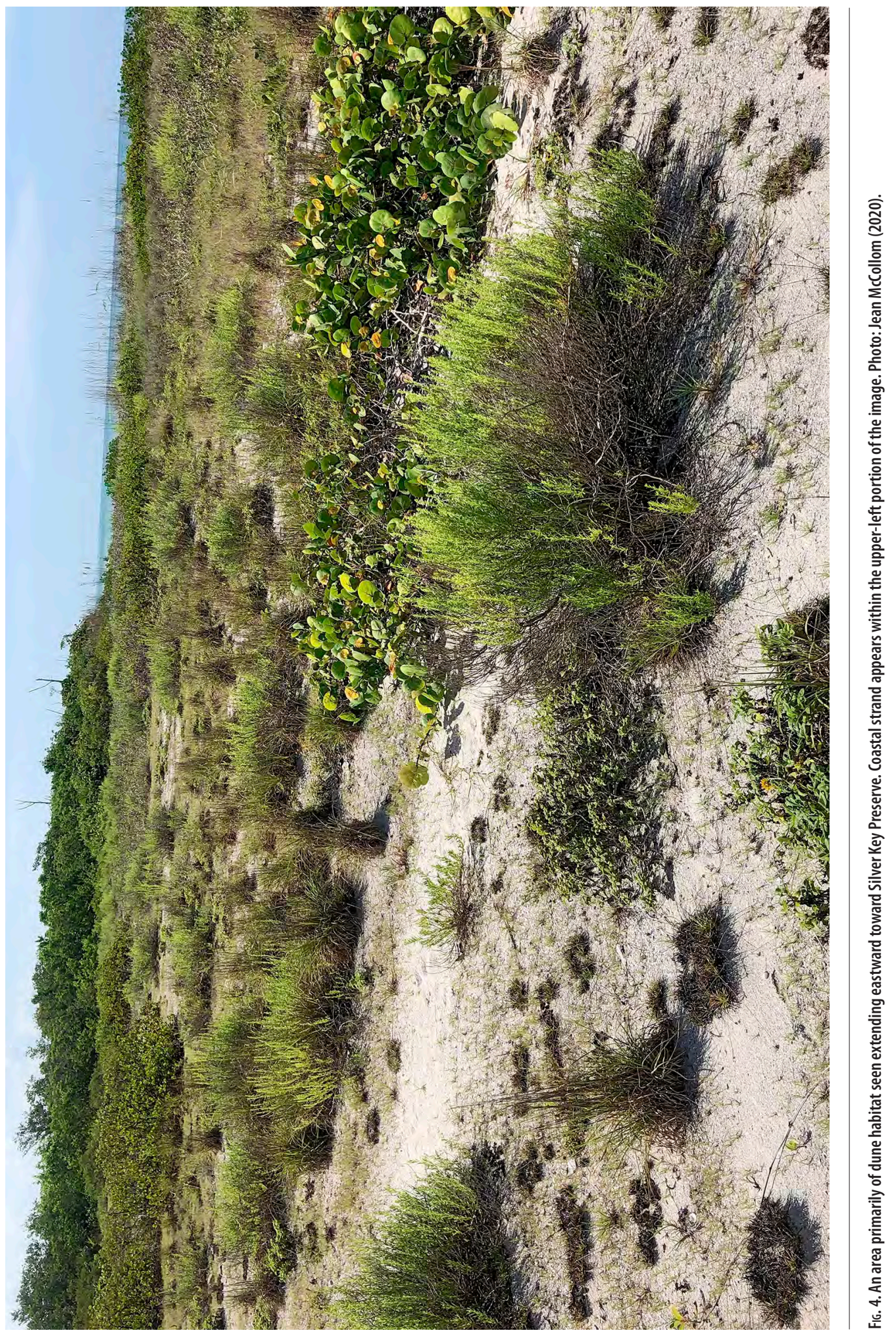




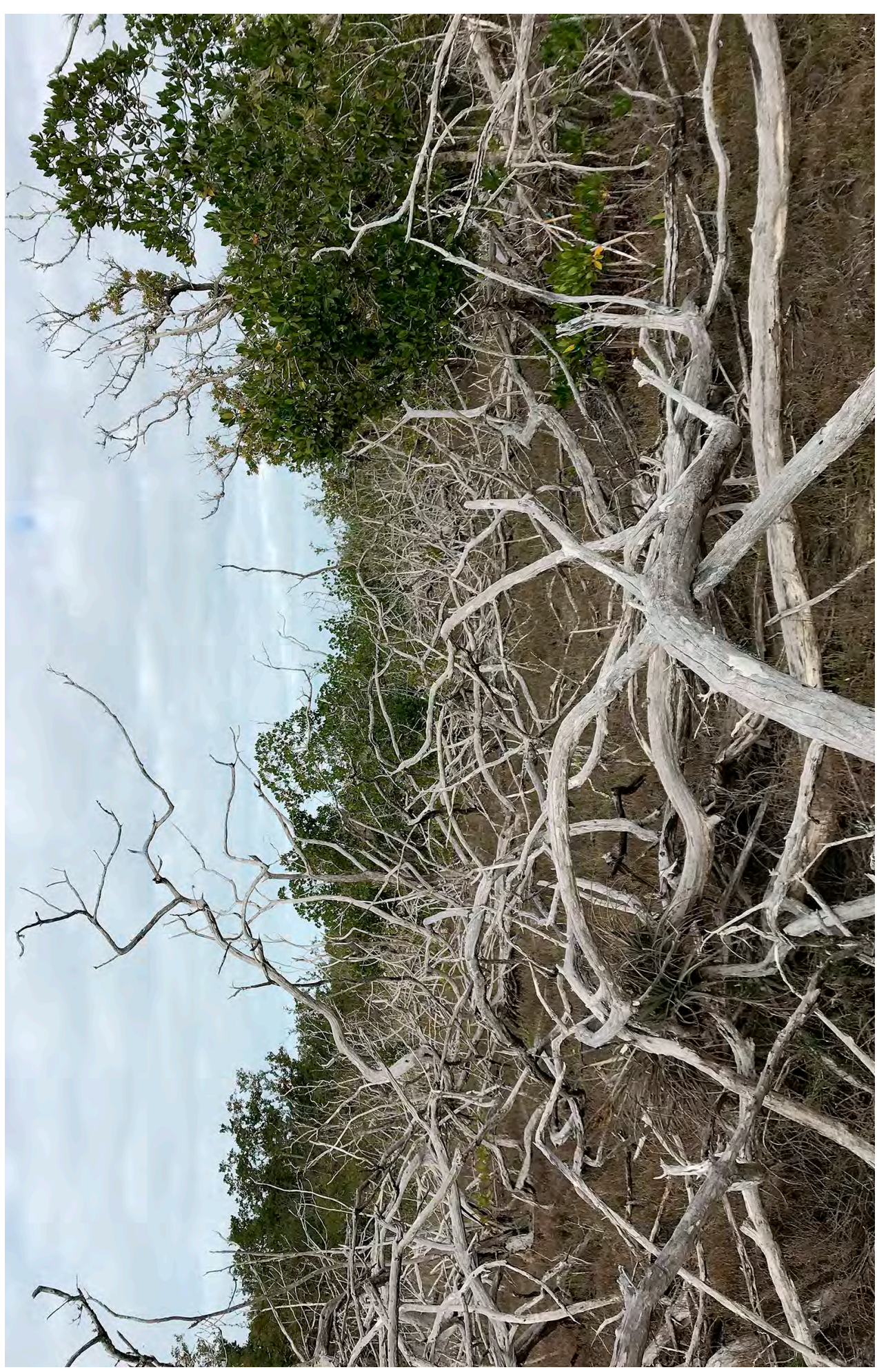


Disturbed marsh dominated by various species.-The State Botanical Site exhibits such marshes, which are generally small. Prominent, in one or more of them are Acrostichum danaeifolium, Amaranthus australis, Baccharis halimifolia, Bacopa monnieri, Cladium jamaicense, Cyperus odoratus, Eupatorium serotinum, Panicum dichotomiflorum var. bartowense, Pluchea odorata, Sesuvium maritimum, Sesuvium portulacastrum, Setaria magna, and Typha domingensis.

Stereotypical salt marsh.-We observed one example of this type of marsh (Fig. 1). Located inland (within Frannie's Preserve [SCCF], at a site south of the Sanibel Slough), it was linear and measured ca. $530 \mathrm{~m}$ long and up to $32 \mathrm{~m}$ wide. Prominent, were Borrichia frutescens, Salicornia ambigua, Sesuvium portulacastrum, Sporobolus virginicus, and Suaeda linearis (Appendix 1 provides a more complete list of the species present). Despite the prevalence of salt marsh species therein, we know of no direct connection between this marsh and saltwater. The marsh is bounded to the north and south by Conocarpus forest (i.e., mangrove habitat [see below]) and various upland habitats, respectively.

Concluding remarks about marsh.-Clark (1976, p 34) characterized salt-water intrusion into Sanibel's ground and surface waters as "a major problem," indicating six natural and artificial mechanisms for the process. He also said (p. 57) that "because Sanibel has a periodically brackish water-table aquifer, almost all [of its] plant species are at least partially salt tolerant" (language between brackets is ours). Thus, we deem it unrealistic to distinguish between freshwater and salt-water marshes on Sanibel. Instead, we interpret-to different degrees-all of Sanibel's marshes (even the Spartina marshes) to be salt-water/potential salt-water marshes. In that connection, Clark (1976, p. 57) stated that Spartina bakeri “... requires seasonal flooding with fresh to brackish water" and that the "... ability to prosper under a varying salinity regime [has] permitted ... Spartina to become the dominant plant community on much of ... [Sanibel's] wetlands."

\section{Mangrove forest}

One or more of four native, arborescent species define and predominate within mangrove forest: Avicennia germinans (Black Mangrove), Conocarpus erectus (Buttonwood), Laguncularia racemosa (White Mangrove), and Rhizophora mangle (Red Mangrove). Mangrove forest is frequent and widespread on the Island. We recognize four main subcategories, thereof.

Avicennia forest.-An excellent, small example exists north of Woodring Rd., near the northern shore of the Island. There Avicennia germinans is the sole mangrove species and the dominant species present. Additional Avicennia forest occurs by the western side of Tarpon Bay Rd., ca. 1/8 mi north of the intersection of Tarpon Bay Rd. and Sanibel-Captiva Rd. (Fig. 1). Aside from vegetation bordering Tarpon Bay Rd., the sole trees present are of A. germinans.

Conocarpus forest.- In recent years, because of stabilization of the water table, Conocarpus erectus has expanded its range considerably on the Island (Chris Lechowicz [Director of Wildlife Habitat Management at SCCF], pers. comm. to George Wilder, 11 Feb 2020). Indeed, SCCF considers C. erectus a pest plant and eradicates population(s) thereof. Conocarpus forest occupies both lowlands and uplands. Two examples are indicated. 1. A small forest situated within the Bailey Tract (DDNWR). Here C. erectus is the sole tree present. Different parts of the forest grow either on depressed dry land or land partially submerged in water. The portion on dry land has an herbaceous understory of Acrostichum danaeifolium. 2. Forest located near open water, just southeast of the footbridge at Bowman's Beach Park. Here, too, C. erectus is the sole tree present. There is a dense understory, solely of Borrichia frutescens. At multiple locations on the Island we noted individuals of $C$. erectus that bore adventitious roots basally on their trunks.

Laguncularia forest.-We only noted small areas, thereof, on the Island. For example, there exists a fringe of L. racemosa, of undetermined length, bordering a salt-water channel within Bowman's Beach Park.

Rhizophora forest.-This abounds on the Island. For example, one observes extensive swaths, thereof, both east and west of Dixie Beach Blvd. (Fig. 1) and south of Woodring Rd. Within the swaths, R. mangle is the sole, or the predominant, species of trees present. Rhizophora mangle also inhabits ditches, e.g., along the western side of Dixie Beach Blvd. and near the northern terminus of Tarpon Bay Rd. 


\section{Ruderal land}

Included, are dirt roads, roadsides, trails, flower beds, shrub beds, lawns, fields, and other disturbed areas. It was sometimes unclear whether land that appeared as ruderal was so. For example, in a northeastern portion of Bowman's Beach Park we classified as ruderal land certain small, occasionally mowed, field-like areas of unknown history. Those areas manifested native species (e.g., Aristida purpurascens, Scleria verticillata, Stillingia sylvatica) and, perhaps, were vestiges of the Island's original grassland.

\section{Habitats not emphasized herein}

We discuss minimally two additional kinds of habitats of the Island, because they manifest little plant diversity. 1. Aquatic habitat.-Extensive and widespread, this habitat includes numerous ponds (e.g., large waterreclamation ponds managed by the City of Sanibel), canals, and the Sanibel Slough. We suspect that the low diversity, therein, reflects poor water quality-partly a consequence of saltwater intrusion. Bacopa monnieri is often conspicuous in aquatic habitat. 2. Pond-Apple swamp.-We observed two small examples, thereof, at the State Botanical Site. Annona glabra (Pond Apple) was dominant.

\section{Floristic inventory}

\section{Taxonomic analysis of present data}

The Island exhibited 119 families, 397 genera, 611 species (including Citrus sp. and Kalanchoe xhoughtonii), and 621 infrageneric taxa of vascular plants. Between parentheses, the numbers of families, genera, and infrageneric taxa are indicated, respectively, for each of the following major groups: pteridophytes $(8,12,16)$, gymnosperms $(3,4,5)$, angiosperms $(108,381,600)$, monocotyledons $(24,96,186)$, and dicotyledons sensu lato $(84,285,414)$.

The seven largest families of monocotyledons, as gauged by the numbers of infrageneric taxa present, are Poaceae (78), Cyperaceae (44), Arecaceae (17), Bromeliaceae (9), Orchidaceae (6), Agavaceae (5), and Commelinaceae (4) (for each family the number of infrageneric taxa is listed between parentheses). The families Poaceae and Cyperaceae, collectively exhibited 19.6\% of all 621 infrageneric taxa listed (i.e., 122 taxa).

The 13 largest families of dicotyledons sensu lato are Asteraceae (57), Fabaceae (54), Euphorbiaceae (24),

Rubiaceae (17), Convolvulaceae (15), Amaranthaceae (13), Malvaceae (12), Apocynaceae (10), Cactaceae (9), Lamiaceae (9), Myrtaceae (9), Onagraceae (9), and Solanaceae (9). The families Asteraceae and Fabaceae, collectively exhibited $17.9 \%$ of all 621 infrageneric taxa listed (i.e., 111 taxa).

\section{Infrageneric taxa and habitats}

Habitats are listed for all infrageneric taxa reported here (Appendix 1). On the Island, ruderal land exhibited the highest percentage of infrageneric taxa. Intermediate percentages of taxa grew in hammock, coastal strand, dune habitat, shell mounds, and marsh. Lowest percentages occurred within mangrove habitat and beach habitat.

Supporting data are presented. Each number, below, refers solely to the infrageneric taxa that we noted inside of a habitat, not to taxa whose sole association with the habitat was occurrence within ecotone(s) involving that habitat. For each habitat indicated, listed between parentheses are the number of infrageneric taxa observed therein and the percentage which that number represents of all 621 infrageneric taxa reported here: ruderal land (499, 80.4\%); hammock (125, 20.1\%); coastal strand (121, 19.5\%); dune habitat (120, 19.3\%); shell mounds (90, 14.5\%); marsh (85, 13.7\%); mangrove habitat (36, 5.8\%); and beach habitat (26, 4.2\%).

For four subcategories of habitats, we also determined the numbers of infrageneric taxa present and their percentages of all 621 infrageneric taxa (Appendix 1): oak hammock (42, 6.8\%); coastal strand at Silver Key Preserve (73, 11.8\%); the Calusa shell mound within the DDNWR (57, 9.2\%); and the stereotypical salt marsh (25, 4.0\%).

\section{Infrageneric taxa of the five general areas of the Island}

Listed between parentheses, is the number of infrageneric taxa that we noted within each of the five general areas of the Island: the State Botanical Site (221); Bowman's Beach Park (286); the DDNWR (399); SCCF (392); and all other properties (483; Appendix 1). 
Each infrageneric taxon inhabited from one to five of the general areas, and for individual taxa the number of general areas occupied constituted a crude measure of their geographic dispersal on the Island. After each number of general areas indicated below, listed between parentheses are the number of infrageneric taxa that we noted therein and the percentage of all 621 infrageneric taxa represented by that number: one area (184, 29.6\%); two areas (97, 15.6\%); three areas (87, 14.0\%); four areas (124, 20.0\%); and five areas (129, 20.8\%). Based on the number of general areas they occupied, the individual taxa ranged from narrowly dispersed (i.e., occupying one general area) to widely dispersed on the Island (occupying five general areas).

\section{Native and endemic taxa}

Four hundred and twenty (67.6\%) of the 621 infrageneric taxa recorded were native to Florida (Appendix 1). Between parentheses, the number and percentage of native infrageneric taxa within each major group of vascular plants are listed, respectively: pteridophytes (11, 68.8\%); gymnosperms (4, 80\%); angiosperms (405, $67.5 \%)$; monocotyledons (116, 62.4\%); and dicotyledons sensu lato (289, 69.8\%). We have excluded two taxa, Canna sp. and Imperata cylindrica sensu lato, from these determinations, because $\mathbf{1}$. Canna is known from both native- and exotic species in Florida, making the status of Canna sp. indeterminable, and 2. Imperata cylindrica sensu lato is a global species which in Florida consists both of native and exotic constituents (Hall 2019).

Thirteen (2.1\%) of the infrageneric taxa were endemic to Florida: Agave decipiens, Aristida patula, Carex vexans, Croton glandulosus var. floridanus, Eragrostis pectinacea var. tracyi, Eupatorium mikanioides, Flaveria floridana, Harrisia aboriginum, Helianthus debilis subsp. debilis, Jacquemontia reclinata, Micranthemum glomeratum, Pectis linearifolia, and Schizachyrium rhizomatum. Of those taxa, Helianthus debilis subsp. debilis and Jacquemontia reclinata are considered native solely to eastern Florida (Wunderlin \& Hansen 2011); thus, we suspect that our observations, thereof, were of planted and/or escaped material.

\section{Exotic taxa}

One hundred and ninety-nine (32.0\%) of the infrageneric taxa observed on the Island are exotic within Florida (not including Canna sp. and Imperata cylindrica sensu lato; Appendix 1).

The Florida Exotic Pest Plant Council (FLEPPC 2019) has recognized two categories of plant species exotic within Florida, that pose especial threats to the ecology of the State, overall, i.e., Category I and Category II (those categories indicate decreasing degree of threat; FLEPPC 2019). Noted presently were 35 Category I species (Abrus precatorius, Acacia auriculiformis, Albizia lebbeck, Asparagus aethiopicus, Bischofia javanica, Casuarina equisetifolia, Cenchrus purpurea, Cupaniopsis anacardioides, Dioscorea alata, Dioscorea bulbifera, Eugenia uniflora, Ficus microcarpa, Imperata cylindrica, Lantana strigocamara, Ludwigia peruviana, Lygodium microphyllum, Melaleuca quinquenervia, Melinis repens, Nephrolepis brownii, Nephrolepis cordifolia, Panicum repens, Psidium guajava, Ruellia simplex, Scaevola taccada, Schefflera actinophylla, Schinus terebinthifolia, Senna pendula, Solanum viarum, Sporobolus jacquemontii, Syngonium podophyllum, Syzygium cumini, Thespesia populnea, Tradescantia spathacea, Urena lobata, and Urochloa mutica) and 35 Category II species (Agave sisalana, Antigonon leptopus, Casuarina cunninghamiana, Cenchrus setaceus, Cocos nucifera, Crassocephalum crepidioides, Cryptostegia madagascariensis, Cyperus involucratus, Dactyloctenium aegyptium, Dracaena hyacinthoides, Eulophia graminea, Ficus altissima, Kalanchoe $\times$ houghtonii, Kalanchoe pinnata, Leucaena leucocephala, Livistona chinensis, Macroptilium lathyroides, Melia azedarach, Momordica charantia, Murraya paniculata, Platycerium bifurcatum, Pteris vittata, Richardia grandiflora, Ricinus communis, Ruellia blechum, Spermacoce verticillata, Sphagneticola trilobata, Stachytarpheta cayennensis, Talipariti tiliaceum, Terminalia catappa, Terminalia muelleri, Tribulus cistoides, Urochloa maxima, Vitex trifolia, and Washingtonia robusta).

On the Island, we also observed sterile individuals of Bauhinia sp., Chamaedorea sp., and Phoenix sp.taxa which might be equivalent to three additional species listed by FLEPPC (2019), viz., Bauhinia variegata (Category I), Chamaedorea seifrizii (Category II), and Phoenix reclinata (Category II), respectively. The 35 Category I species and the 35 Category II species comprised $42.7 \%$ and $41.2 \%$ of all 82 Category I species and 85 Category II species recognized for Florida, respectively. 
We rank eight species (six were listed by FLEPPC 2019) as being among the most troublesome exotic species on the Island: Agave sisalana, Cyperus hyalinus, Dracaena hyacinthoides, Nephrolepis brownii, Panicum repens, Schinus terebinthifolia, Selenicereus pteranthus, and Sporobolus jacquemontii.

\section{Native taxa deemed rare by the Florida Department of Agriculture and Consumer Services (2020) and by Gann et al. (2002)}

The Florida Department of Agriculture and Consumer Services (FDACS 2020) and Gann et al. (2002) listed infrageneric taxa which they considered rare in Florida and in South Florida, respectively. During the present study we documented 46 of those taxa (Table 1). Sixteen taxa were represented by individuals that we deemed solely to be planted. Of the remaining 30 taxa, some consisted entirely of wild, non-planted individuals and others were at least not clearly represented solely by planted individuals. Below, we focus on the 30 taxa.

For Florida, FDACS (2020) ranked eight and 14 of the 30 taxa as Endangered and Threatened, respectively. For south Florida, Gann et al. (2002) ranked one, three, and seven of the 30 taxa as Extirpated, Historical, and Critically Imperiled, respectively.

Below, we discuss four of the 30 rare taxa individually.

Celosia nitida (West Indian Cock's Comb).-This species is State-listed as Endangered. In Florida, it inhabits seven counties within the central and southern peninsula (Wunderlin et al. 2020). Celosia nitida is scarce on the Island, growing solely in two habitats/habitat groups within the DDNWR. 1. We observed conspicuous clumps in cactus hammock situated north of Sanibel-Captiva Rd. Plants were also abundant on/ along a 141-feet portion of a trail which traversed that hammock. 2. A small clump grew on the Calusa shell mound situated within the DDNWR.

Celtis pallida (Desert Hackberry). - This species is State-listed as Endangered, being recorded from several sites in Charlotte and Lee Counties (Gann et al. 2002; Wunderlin \& Hansen 2016). It also occurs in Arizona, New Mexico, Texas, Mexico, Argentina, Bolivia, and Paraguay (Correll \& Johnston 1970; Austin 2004).

We know of one clump from the Island, which we describe below. It is situated on the Calusa shell mound within the DDNWR, and William Brumbach likely discovered it, possibly in 1972 (Gann et al. 2002). The Florida Champion Trees Register (FDACS 2021) lists the clump, apparently as one tree, as an "Emeritus National Champion."

We recognized three individuals within the clump. They were woody, considerably branched, and each culminated basally in a separate short, prostrate stem anchored to the ground. One individual measured $9.5 \mathrm{~m}$ long. The thickest stem of the clump was ca. $12.5 \mathrm{~cm}$ in diameter. Most thick stems were ascending or erect. The bark of the thick stems was mainly smooth.

Parts of certain thick stems were conspicuously necrotic, suggesting advanced age. Because the basalmost stem portions of the three individuals were anchored near one another, and because of their apparently advanced age, we suspect that they might originally have been contiguous, but that they had become separated by the death/degradation of tissues. Thus, the entire clump might be monoclonal.

The stems of $C$. pallida bear sharp-tipped, hard, solitary or horizontally paired, persistent objects which previous workers had interpreted in different ways. Henrickson (2010) considered them "supranodal thorns" (i.e., cauline structures), whereas Small (1933), Correll \& Johnston (1970), Chafin (2000), and Wunderlin and Hansen (2011) called them spines (i.e., foliar structures). Wunderlin \& Hansen (2016) interpreted them specifically—and without explanation—as "stipular thornlike spines."

We follow Henrickson (2010), for these reasons. 1. The foliage leaves are stipulate, but the actual stipules — two per leaf-are bifacial, soft, and thin. They are stem-borne (each bordering its associated petiole), broadest basally, and taper to an acute apex. They measure 1.0 to $2.1 \mathrm{~mm}$ long and 0.3 to $0.5 \mathrm{~mm}$ wide $(\mathrm{n}=8)$, soon turn brown, and are caducous. 2. By contrast, the sharp-tipped objects are axillary to the foliage leaves, occupying the positions of axillary buds. Where a foliage leaf subtends two sharp-tipped objects, those objects represent collateral buds. 3. We (and Henrickson 2010) observed that the sharp-tipped objects vary considerably in length and that the longer ones bear foliage leave(s); thus, those objects are necessarily stems (i.e., thorns), not leaves/stipules. 
TABLE 1. List of species and varieties of rare plants presently reported for Sanibel Island. Certain rankings of rarity are for Florida (Florida Department of Agriculture and Consumer Services [FDACS 2020]) and for south Florida (Gann et al. 2002). One ranking of rarity (superscript s after the name of a taxon) is solely for Sanibel Island; superscript $s$ is used here only for taxa that were listed by FDACS (2020) and by Gann et al. (2002). See Appendix 1 for an accounting of additional taxa that were scarce in the study area. Taxa that we believe were represented in preserves/natural areas solely by planted individuals are listed in bold font; remaining taxa are indicated with non-bold font. Crit. Imp. = critically imperiled; End. = Endangered; Ext. = extirpated; Hist. = historical; Threat. = threatened; $\mathbf{s =}$ a taxon documented during the present study and deemed to be scarce within the study area.

\begin{tabular}{|c|c|c|c|c|c|}
\hline Taxon & FDACS (2020) & Gann et al. (2002) & Taxon & FDACS (2020) & Gann et al. (2002) \\
\hline 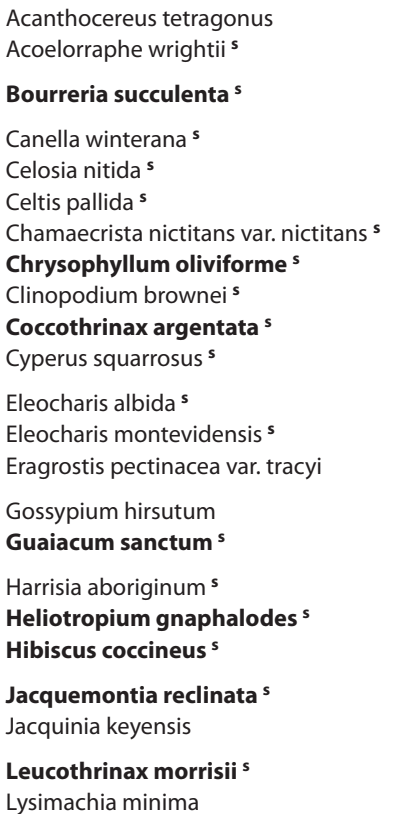 & $\begin{array}{l}\text { Threat. } \\
\text { Threat. } \\
\text { End. } \\
\text { End. } \\
\text { End. } \\
\text { End. } \\
\text { Hist. } \\
\text { Threat. } \\
\text { Threat. }\end{array}$ & $\begin{array}{l}\text { Crit. Imp. } \\
\text { Crit. Imp. } \\
\text { Crit. Imp. } \\
\text { Crit. Imp. } \\
\text { Hist. } \\
\text { Crit. Imp. }\end{array}$ & 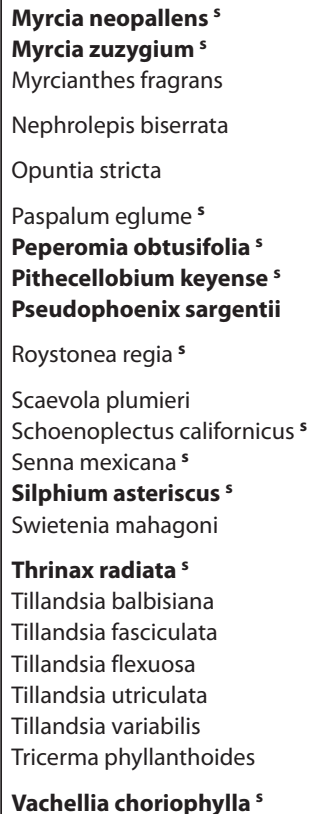 & $\begin{array}{l}\text { Threat. } \\
\text { End. } \\
\text { Threat. } \\
\text { Threat. } \\
\text { Threat. } \\
\text { End. } \\
\text { Threat. } \\
\text { End. } \\
\text { End. } \\
\text { Threat. } \\
\text { Threat. } \\
\text { Threat. } \\
\text { End. } \\
\text { Threat. } \\
\text { End. } \\
\text { Threat. } \\
\text { End. } \\
\text { Threat. } \\
\text { Threat. } \\
\text { End. }\end{array}$ & $\begin{array}{l}\text { Hist. } \\
\text { Crit. Imp. }\end{array}$ \\
\hline
\end{tabular}

Henrickson (2010) stated that on some thorns that bear foliage leaves, those foliage leaves themselves subtend additional thorns. In light of the facts, aforementioned, one commonly applied name for C. pallida, "Spiny Hackberry" (Chafin 2000; Gann et al. 2002; Wunderlin 2011; Wunderlin and Hansen 2016), is botanically inappropriate.

Gossypium hirsutum (Wild Cotton).--This species is State-listed as Threatened. In Florida, G. hirsutum inhabits 11 counties ranging from the southern to northern peninsula (Wunderlin et al. 2020). On the Island the species is common and widespread. There is a considerable, dense population on open ruderal land at Woodring Point (Fig. 1).

Jacquinia keyensis (Joewood).-This species is State-listed as Threatened. It includes small trees and shrubs, the trees having a well-defined trunk and crown (Fig. 6). In Florida it inhabits four southern counties (Wunderlin et al. 2020). On the Island, the plants are widespread, occurring within four of the five general areas presently recognized. The plants occupy diverse habitats and ecotones (Appendix 1); however, they are particularly prominent in coastal strand vegetation at Silver Key Preserve and on open, disturbed terrain situated within another southwestern sector of the Island.

\section{Native and exotic infrageneric taxa that are scarce on the Island}

We deem 257 infrageneric taxa (41.4\% of all 621 infrageneric taxa presently reported) to be scarce on the Island (Appendix 1). Included, among those 257 taxa are 29 of the taxa discussed above, that are State listed as Endangered or Threatened in Florida or that are designated as Critically Imperiled, Extirpated, or Historical in South Florida (FDACS 2020; Gann et al. 2002; Table 1). 


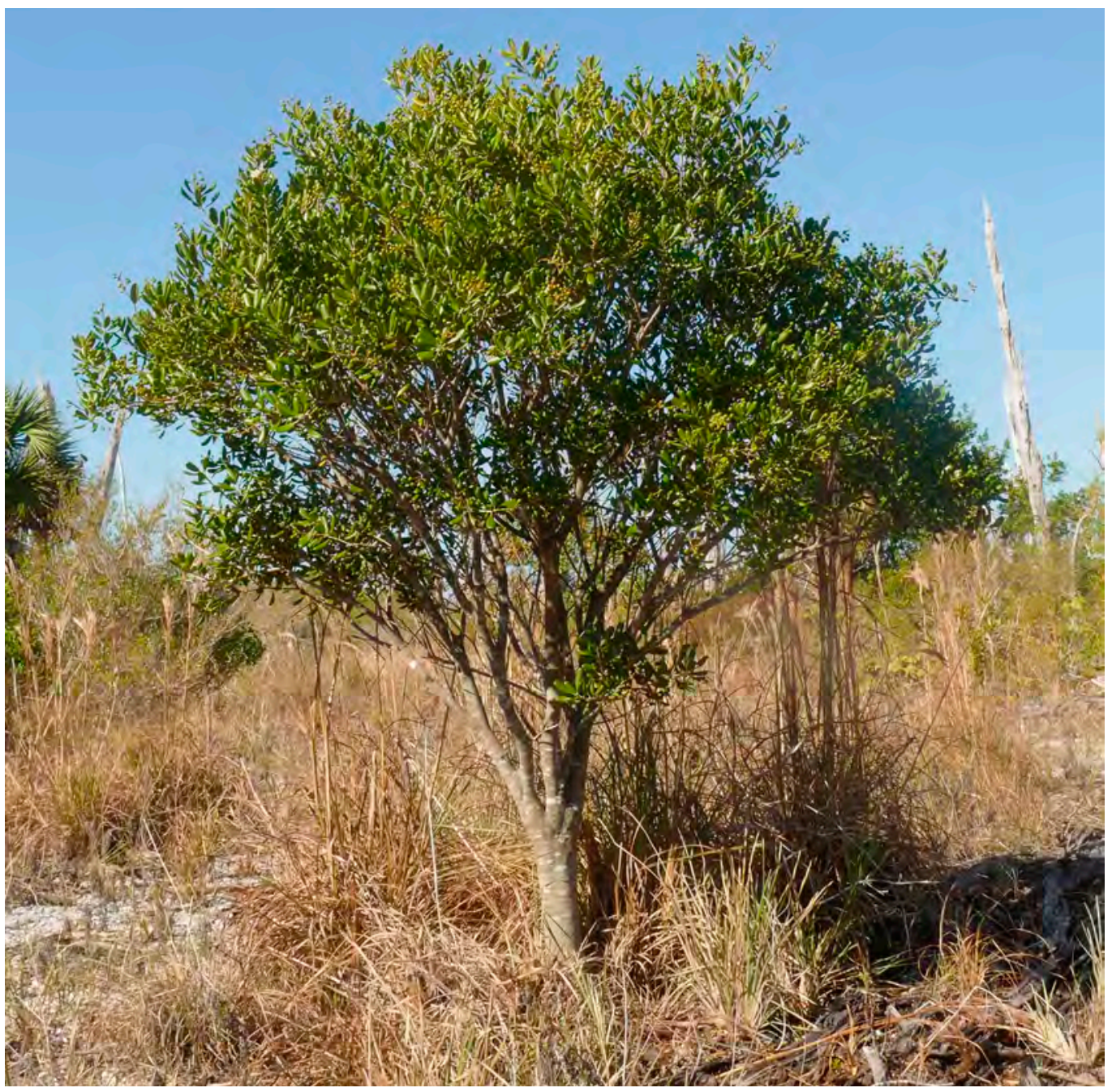

FIG. 6. A tree of Jacquinia keyensis growing near the western terminus of Bowman's Beach Park. Visible, are the well-defined trunk and crown of the tree. Photo: Jean McCollom (2020).

Listed, are examples of taxa which were represented, solely, by one to several individuals/clumps on the Island: Carex vexans, Celtis pallida, Citrus sp., Cordia sebestena, Croton glandulosus var. floridanus, Croton punctatus, Dioscorea alata, Fatoua villosa, Ficus altissima, Ficus citrifolia, Habenaria quinqueseta, Harrisia aboriginum, Ipomoea quamoclit, Jacquemontia reclinata, Lygodium microphyllum, Melaleuca quinquenervia, Myrcia zuzygium, Metopium toxiferum, Pandanus sp., Pentalinon luteum, Persea palustris, Physalis walteri, Platycerium bifurcatum, Poa annua, Tillandsia variabilis, Tillandsia sp. (an apparent intermediate between T. fasciculata and T. utriculata [see Appendix 1, footnotes 4, 5]), Urochloa mutica, and Ximenia americana.

Lemna aequinoctialis was limited to one small pond on public land behind the Bailey Homestead Preserve (SCCF). 


\section{Perspective and comparisons with previous work}

To properly assess Sanibel's flora, one must consider its history of severe disturbances. That history begs the question of whether any part of the Island-even the most luxuriant of hammocks—could be considered pristine. We deem it plausible to consider Sanibel's entire flora as disturbed, both naturally and anthropogenically.

Below, we utilize Cooley's (1955) report as a baseline to assess Sanibel's vascular flora today. Cooley (1955) listed 309 infrageneric taxa of vascular plants for the Island; however, based on synonymies and misapplied names, we revise that number to 300 .

Our inventory does not include 37 of Cooley's (1955) infrageneric taxa. Listed, below are those of his monocotyledonous taxa that we did not inventory (an asterisk after the name of a taxon signifies that it is nonnative in Florida [Wunderlin et al. 2020]): Agave americana*, Cenchrus americanus ${ }^{*}$, Coleataenia rigidula, Cyperus filiculmis, Cyperus pseudovegetus, Cyperus strigosus, Dichanthelium ensifolium var. unciphyllum, Eragrostis pilosa*, Hymenocallis latifolia, Lachnocaulon anceps, Najas guadalupensis, Panicum dichotomiflorum var. dichotomiflorum, Scirpus cyperinus, Sorghum halepense*, Spartina patens, and Sporobolus junceus. The noninventoried taxa of dicotyledons sensu lato were Amaranthus hybridus*, Asclepias verticillata, Baccharis dioica, Berlandiera subacaulis, Cakile lanceolata, Cardiospermum halicacabum*, Chenopodium album*, Euphorbia trichotoma, Froelichia floridana, Galactia parvifolia Rich. (either Galactia parvifolia A. Rich. sensu lato [IRC 2021] or Galactia austrofloridensis A. R. Franck [Franck 2017]), Gamochaeta purpurea, Houstonia procumbens, Lantana depressa (apparently, L. depressa var. sanibelensis), Ligustrum ovalifolium *, Neptunia lutea*, Opuntia ficus-indica*, Polygala incarnata, Sambucus nigra, Stillingia aquatica, Tamarindus indica*, and Thunbergia fragrans*.

Of Cooley's (1955) 37 taxa, aforementioned, 25 (67.6\%) are native to Florida and 22 (59.5\%) occupy wetland habitats to varying degrees (i.e., having wetland indicator status of OBL, FACW, or FAC; USDA 2020).

Pursuant to Cooley's (1955) work, Wunderlin et al. (1980), Herwitz \& Wunderlin (1990), Bradley (2002), and Stalter \& Lamont (2021) did report, collectively, 18 of Cooley's (1955) 37 taxa that we did not inventory. The 19 of Cooley's (1955) taxa that neither we nor they reported were Agave americana, Baccharis dioica, Cardiospermum halicacabum, Cenchrus americanus, Chenopodium album, Cyperus filiculmis, Cyperus pseudovegetus, Dichanthelium ensifolium var. unciphyllum, Eragrostis pilosa, Euphorbia trichotoma, Galactia parvifolia sensu lato, Hymenocallis latifolia, Ligustrum ovalifolium, Neptunia lutea, Opuntia ficus-indica, Sorghum halepense, Spartina patens, Stillingia aquatica, and Tamarindus indica.

On Sanibel, at least three of the above-listed taxa would have occurred well outside of their known ranges in Florida (B. dioica, C. pseudovegetus, and G. parvifolia [Wunderlin et al. 2020]). That circumstance suggests that Cooley (1955) might have misidentified them.

Our total of 621 infrageneric taxa is over twice Cooley's (1955) total of 300 taxa; however, how one explains that incongruity depends on whether one accepts Cooley's (1955) findings at face value. If one affords them face value, then - after 1955—-there would have transpired more than a doubling of taxa on the Island. Also, excluding Sophora tomentosa (which Cooley cited without a varietal name and which has one native, and one exotic variety in Florida), 261 (87.3\%) of Cooley's taxa are native to Florida. By contrast, and as was indicated above, solely $67.6 \%$ of our 621 taxa are native. That disparity plus Sanibel's history of disturbances suggest: 1. that the presumed increase of taxa on Sanibel derived primarily from an influx of exotic species, and 2. that this influx, in turn, resulted from the pronounced disturbances to Sanibel after 1955 (especially following construction of the causeway in 1963).

However, Herwitz and Wunderlin (1990) have speculated that Cooley's inventory was incomplete, based on the pronounced difference in the number of native species reported by Cooley (1955) and by themselves (i.e., 266 [by their count] vs. 432 species, respectively). Unfortunately, that possibility is untestable. We suspect that truth exists in all the interpretations above.

Wunderlin et al. (1980), Herwitz and Wunderlin (1990), Bradley (2002), and Stalter and Lamont (2021) reported, collectively, 134 additional infrageneric taxa for Sanibel that we did not list (Appendix 2). We suspect that certain of those taxa were either extirpated from the Island during development or were misidentified, in 
the latter case because on Sanibel they would have been considerably outside of their known ranges in Florida (e.g., Amaranthus cannabinus, Carex albolutescens, and Sabatia campanulata [Appendix 2, footnote 6; Wunderlin et al. 2020]).

For seven species growing wild on, but apparently never knowingly planted on Sanibel, we provide the first published records of voucher specimens from Lee County: Corchorus aestuans, Cyperus squarrosus, Euphorbia prostrata, Fatoua villosa, Jacquemontia tamnifolia, Leucospora multifida, and Vicia floridana (Cooley 1955; Bradley 2002; Wunderlin et al. 1980; Wunderlin \& Hansen 1985; Herwitz \& Wunderlin 1990; Wilder \& McCombs 2006; Stalter \& Lamont 2021; Wunderlin et al. 2020; The Florida State University Biology Department 2021; University of Florida Herbarium Collections Catalog 2021; Virtual Herbarium 2021).

\section{APPENDIX $1^{1}$}

Table of infrageneric taxa (species, varieties, formas, and hybrids) and of higher-level taxa documented at Sanibel Island during the present study. All species, varieties, and hybrids are listed separately and counted as separate infrageneric taxa. Also listed and counted separately, are two pairs of formas: (1) formas of Sporobolus jacquemontii Kunth which we distinguish according to inflorescence form, and (2) formas of Serenoa repens (W. Bartram) Small which are defined by the color of their foliage leaves. Formas based on flower color and other morphologically based formas (i.e., formas of Euphorbia graminea Jacq.) are indicated after the names of the species to which they belong. After the name of each family and suprafamilial taxon, between parentheses are indicated the numbers reported of genera and separately listed infrageneric taxa within that family or suprafamilial taxon. Ecotones are either 1. at a sharp boundary between habitats and/or 2. within an extended area comprised of the habitats.

\footnotetext{
${ }^{1}$ We follow the nomenclature of Wunderlin et al. (2020; as listed 16 Oct 2020), with the following exceptions. (1) We recognize the family Lemnaceae, which Wunderlin and Hansen (2011) and Wunderlin et al. (2020) submerged into Araceae. (2) We recognize Imperata cylindrica (L.) P. Beauv. sensu lato (as did Hall [2019]) rather than the included taxa Imperata brasiliensis Trin. and Imperata cylindrica (L.) P. Beauv. sensu stricto. (3) We recognize Solidago sempervirens L. subsp. mexicana (L.) Semple (as did Semple and Cook [2006]) rather than Wunderlin et al.'s (2020) non-varietal listing of this species (4) We recognize solely Symphyotrichum subulatum (Michx.) G.L. Nesom rather than either of two segregate taxa, Symphyotrichum bahamense (Britton) G.L. Nesom and Symphyotrichum expansum (Poeppig ex Spreng.) G.L. Nesom. (5) We follow Wunderlin et al. (2018) in recognizing Opuntia humifusa (Raf.) Raf. sensu lato, rather than listing the segregate taxon/taxa Opuntia austrina Small and Opuntia mesacantha Rafinesque. (6) We recognize varieties of Conocarpus erectus L., Digitaria ciliaris (Retz.) Koeler, Eragrostis ciliaris (L.) R. Br., and Paspalum setaceum Michx. (as did Long and Lakela [1971], Wipff [2003], Peterson [2003], and Allen and Hall [2003], respectively). Wunderlin et al. (2020) did not recognize varieties of those species. (7) We recognize Digitaria filiformis (L.) Koeler var. villosa (Walter) Fernald (as did Wipff [2003], whereas, Wunderlin et al. (2020) subsumed that variety within Digitaria filiformis (L.) Koeler var. filiformis. (8) We recognize Sonchus asper (L.) Hill forma inermis (Bisch.) G. Beck (as did Fernald [1950]) and Serenoa repens (W. Bartram) Small forma glauca H.N. Moldenke, contrary to Wunderlin et al. (2020). (9) We recognize the names Lipocarpha micrantha (Vahl) G.C. Tucker (utilized by Wunderlin and Hansen [2011]) and Lipocarpha squarrosa (L.) Goetghebeur (listed as a synonymn by Wunderlin et al. [2020]) rather than replacing them with the names applied, respectively, by Wunderlin et al. (2020): Cyperus subsquarrosus (Muhl.) Bauters and Cyperus neochinensis (Tang. \& F.T. Wang) Bauters.

${ }^{2}$ Ms. Martha McCombs contributed importantly to SWF; hence, on the label of each herbarium sheet from SWF George Wilder's name and Martha McCombs' name precede the collection number of each specimen, a circumstance not duplicated in this appendix.

${ }^{3}$ We observed sterile individuals not represented here, but probably of Crinum americanum, at single locations within each of the DDNWR and land managed by SCCF.

4,5 Observed, but not documented, were several plants which appeared intermediate between typical individuals of these two species. In the intermediate plants the diameters of the foliage leaves resembled those of Tillandsia fasciculata, but were less than those typical of Tillandsia utriculata. Too, in the intermediate individuals the inflorescences were shorter than typical inflorescences of T. utriculata. By contrast, by having loosely branched, rather than densely branched, inflorescences the intermediate plants resembled T. utriculata rather than T. fasciculata.

${ }^{6}$ We also observed immature fertile individuals not represented here, but probably of Cyperus tetragonus, at single locations within each of the State Botanical Site and public land included within the "Other" category.

${ }^{7}$ In our material of Eragrostis elliottii the length of the second glume was often outside of the range of lengths specified for E. elliottii by Peterson (2003) and Wunderlin and Hansen (2011).

8,9 We sometimes lacked confidence in distinguishing Dichondra caroliniensis from Dichondra micrantha. Wunderlin et al (2019) stated the following about those two species: "Dichondra micrantha is only subtly distinct and additional research is needed to clarify its taxonomy and distribution."

${ }^{10}$ Herein, we recognize Chiococca alba (L.) Hitchc. sensu lato; however, different specimens from Sanibel are attributable to either of two segregate taxa: Chiococca alba (L.) Hitchc. sensu stricto (Wilder \& McCombs 43340, 43382) and Chiococca parvifolia Wullschl. ex Griseb. (Wilder \& McCombs 43341, 43342, 43384, 43387, 43388) (Franck 2021 submitted).

${ }^{11}$ Our voucher specimen is from a plant of Hamelia patens var. patens, but we did not assess varietal status/statuses for the other individuals of $H$. patens that we encountered at Sanibel.

12 Wunderlin and Hansen (2011) and Wunderlin et al. (2019), collectively, characterized the anthers of Physalis angulata as blue, bluish, and blue-tinged. Yet, we documented different plants which we attributed to $P$. angulata that had yellow anthers (Wilder \& McCombs 42487, 42676) and that had blue anthers (Wilder \& McCombs 43106).
} 
KEY TO SYMBOLS/ABBREVIATIONS IN APPENDIX 1

TAXON (Taxa are listed in the left column.)

Preceding Name of Taxon:

\begin{tabular}{|l|l}
\hline$a$ & endemic to Florida \\
\hline$*$ & exotic in Florida \\
\hline$!$ & a taxon that is not clearly native to, or exotic within, Florida (Canna sp.; Imperata cylindrica) \\
\hline
\end{tabular}

Following Name of Taxon:

\begin{tabular}{|c|l|}
\hline[] & relevant synonym(s) or names(s) previously used but now considered misapplied \\
\hline ( ) & color formas and other notes (e.g., habitats occupied other than the main habitats specified herein) \\
\hline Scarce & scarce on Sanibel Island \\
\hline $\begin{array}{c}\text { FLEPPC I or } \\
\text { FLEPPC II }\end{array}$ & exotic taxa recognized as Category I or Category II by the Florida Exotic Pest Plant Council (FLEPPC 2019) \\
\hline & $\begin{array}{l}\text { the five-digit Wilder \& McCombs collection }{ }^{2} \text { number of a voucher specimen or of a voucher photograph of } \\
\text { that taxon }\end{array}$ \\
\hline
\end{tabular}

HABITAT (All habitats)

\begin{tabular}{|c|l}
\hline $\mathrm{X}$ or $\mathbf{X}$ & present within the habitat indicated, away from the habitat boundary
\end{tabular}

Habitats are listed in the seven vertical columns at the right of Appendix:

\begin{tabular}{|c|l|}
\hline \multirow{2}{*}{ Beach \& du } & $\mathrm{X}=$ present in beach habitat \\
\cline { 2 - 3 } & $\mathbf{X}=$ present in dune habitat \\
\hline \multirow{2}{*}{ Coastal str } & $\mathrm{X}=$ present in coastal strand habitat outside of Silver Key Preserve \\
\cline { 2 - 3 } & $\mathbf{X}=$ present in coastal strand habitat within Silver Key Preserve \\
\hline \multirow{2}{*}{ Hammock } & $\mathbf{X}=$ present in hammock other than the oak hammock within the DDNWR \\
\cline { 2 - 3 } & $\mathbf{X}=$ present in oak hammock within the DDNWR \\
\hline Mangr & $\mathrm{X}=$ present in mangrove habitat \\
\hline \multirow{2}{*}{ Marsh } & $\mathrm{X}=$ present in marsh other than the stereotypical salt marsh \\
\cline { 2 - 3 } & $\mathbf{X}=$ present in the stereotypical salt marsh (in Frannie's Tract managed by SCCF) \\
\hline Rud & $\mathrm{X}=$ present on ruderal land \\
\hline \multirow{2}{*}{ Shell $m$} & $\mathrm{X}=$ present on the shell mound at Woodring Point \\
\cline { 2 - 3 } & $\mathbf{X}=$ present on the Calusa shell mound by the western terminus of Wildlife Drive in the DDNWR \\
\hline
\end{tabular}

Ecotones

Each ecotone is between the habitat indicated in the associated column and the alternative habitats/ habitat groups indicated by the superscript letter(s):

\begin{tabular}{|c|l}
\hline$X^{A}$ & Aquatic habitat \\
\hline$X^{D}$ & Dune habitat \\
\hline$X^{M}$ & Marsh habitat \\
\hline$X^{\text {MA-R }}$ & Boundary between hammock-mangrove ecotone and ruderal land \\
\hline$X^{\text {MN }}$ & Mangrove habitat \\
\hline$X^{R}$ & Ruderal land \\
\hline$X^{\text {ST }}$ & Coastal strand habitat \\
\hline
\end{tabular}

\section{LOCATION}

\begin{tabular}{|c|l|}
\hline $\mathrm{B}$ & State Botanical Site managed by DDNWR \\
\hline $\mathrm{Bb}$ & Bowman's Beach Park managed by the City of Sanibel \\
\hline $\mathrm{D}$ & $\begin{array}{l}\text { Ding Darling National Wildlife Refuge (DDNWR) and other lands managed by the Refuge but excluding } \\
\text { the State Botanical Site }\end{array}$ \\
\hline $\mathrm{S}$ & Sanibel-Captiva Conservation Foundation (SCCF) managed properties \\
\hline $\mathrm{O}$ & All of Sanibel Island not covered by the four areas above \\
\hline$?$ & Location was undetermined \\
\hline
\end{tabular}




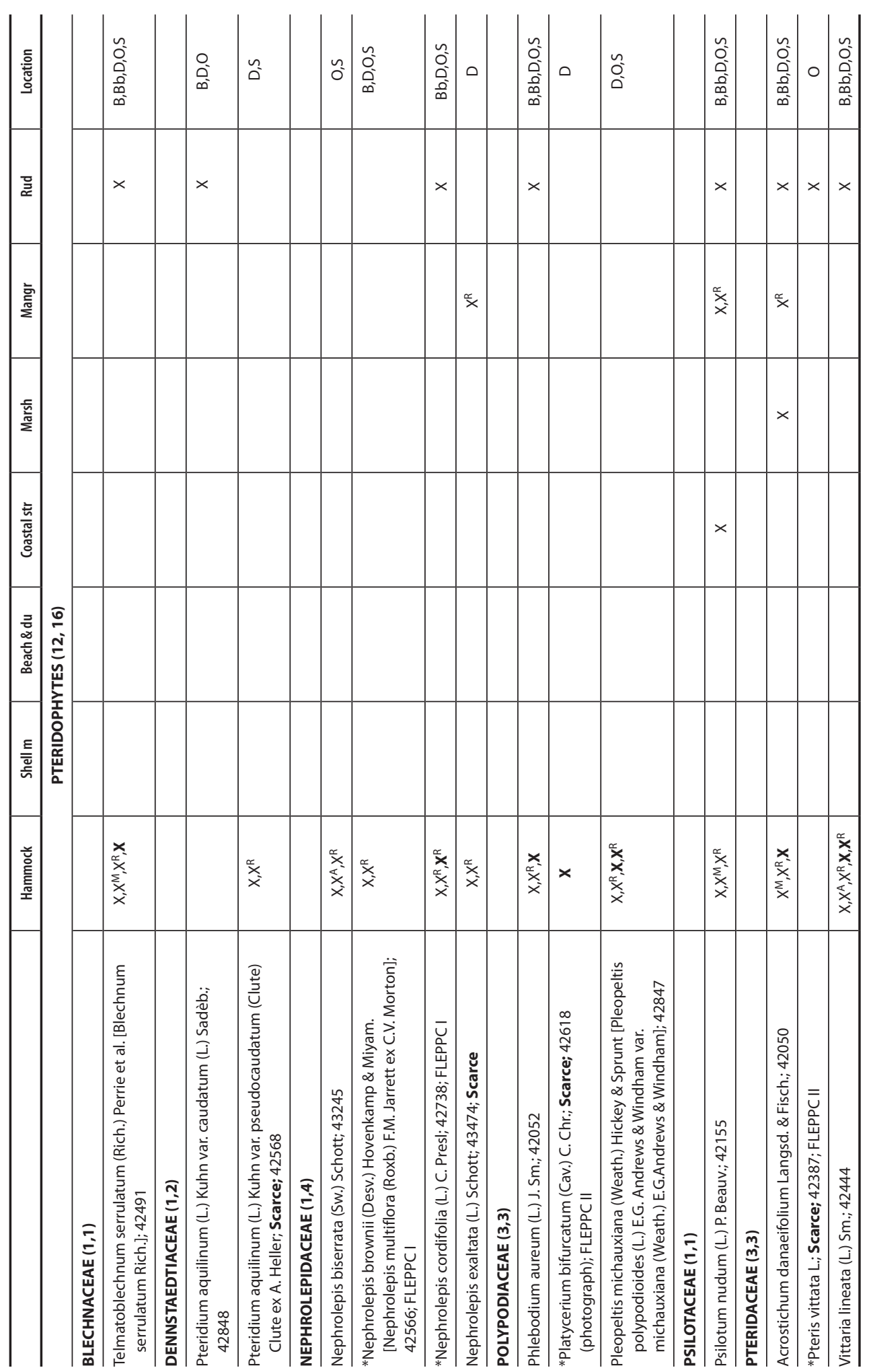




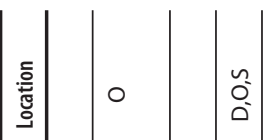
竞

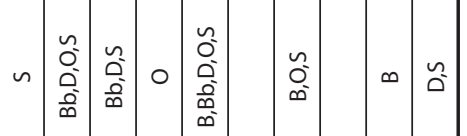

马्ञ

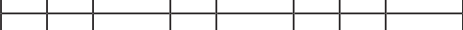

畗

$\stackrel{\Re}{x}$

$\stackrel{\circ}{x}$

产

$\frac{\frac{5}{5}}{\frac{5}{5}}$

$\underset{\substack{x \\ \times}}{\stackrel{x}{x}} \quad \times$

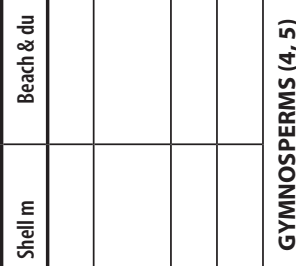
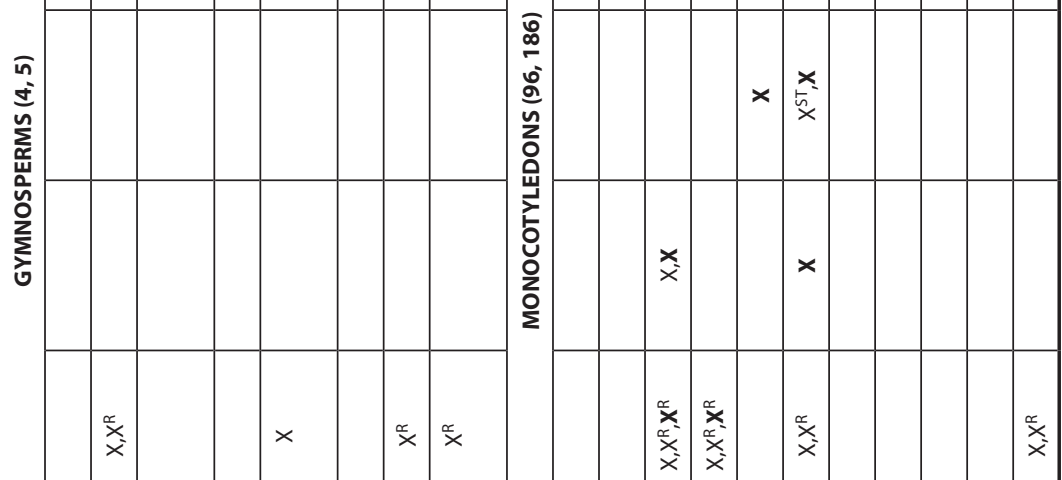

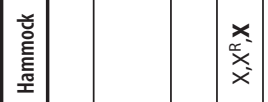

$\approx \tilde{x}$

$\underset{\substack{x \\ x}}{\stackrel{x}{x}}$
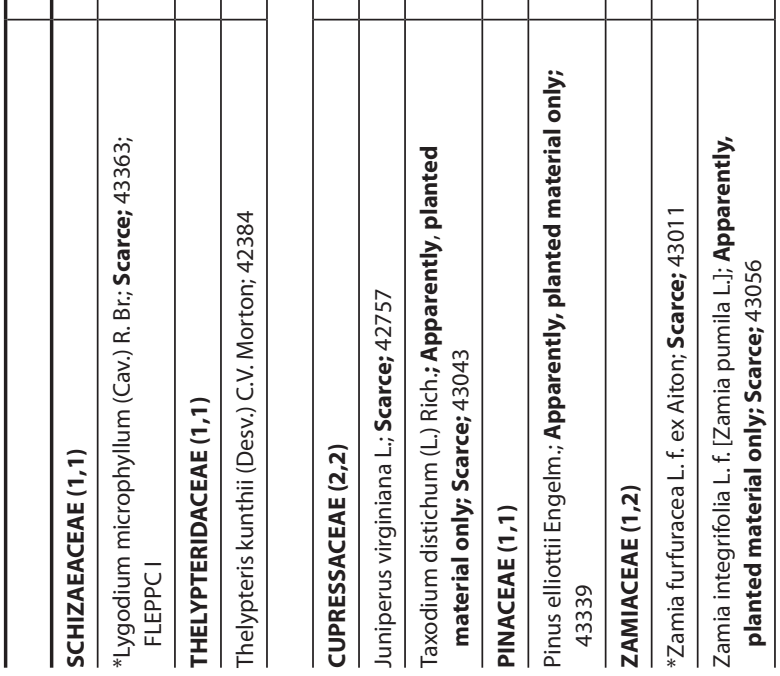

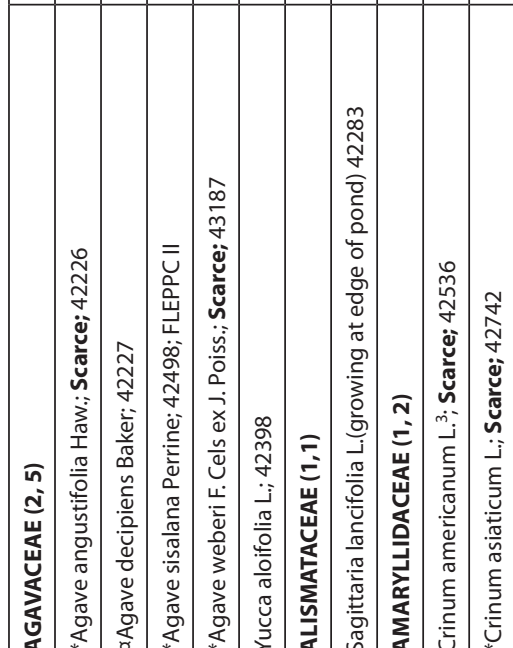




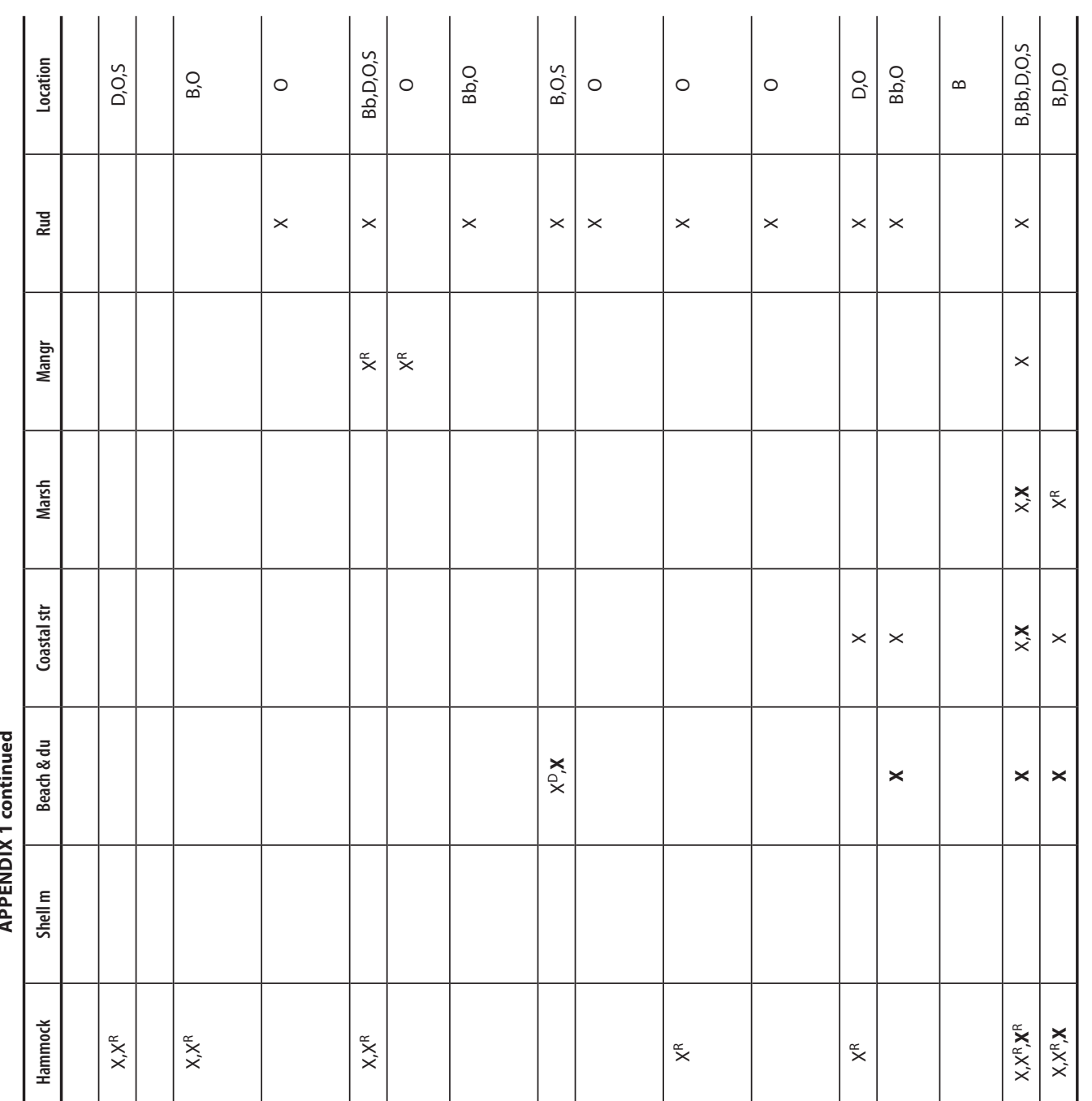

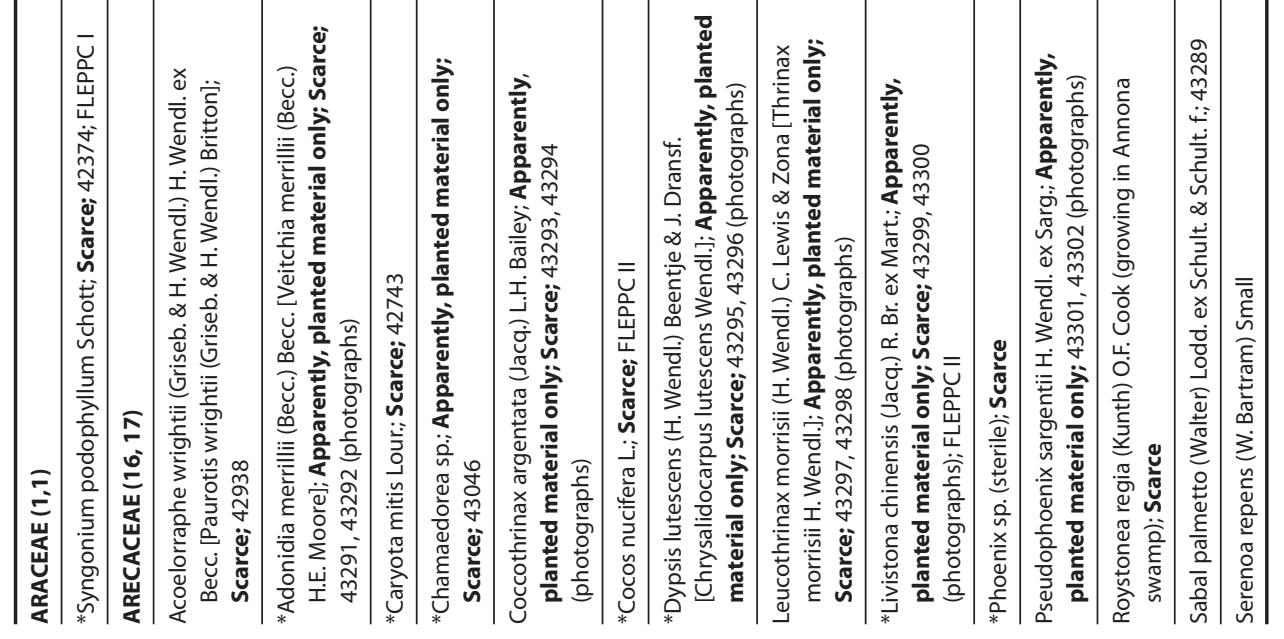




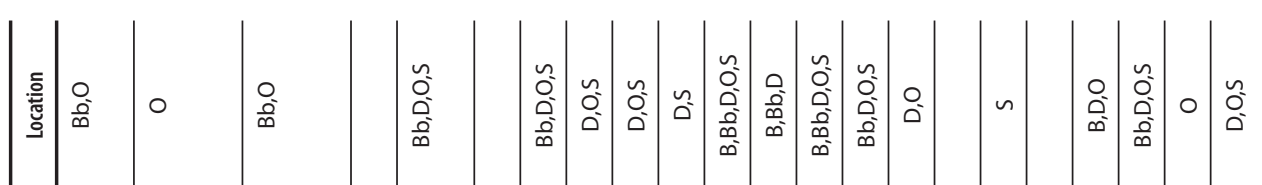

몰

畗

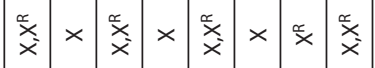

高

$\stackrel{\circ}{\times} \quad \times \quad \times \quad \times \quad \times \quad \times \quad \times \quad \times$

$\sqrt{n} \times$

$\underset{x}{\stackrel{x}{x}} \quad \stackrel{x}{x}$

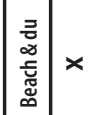

高

$\times \quad \underset{\times}{\stackrel{x}{\times}} \quad \underset{\times}{\stackrel{x}{\times}} \underset{\times}{\times}$

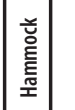

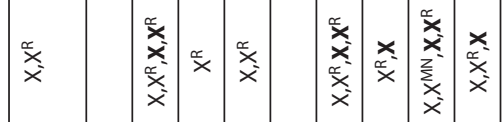

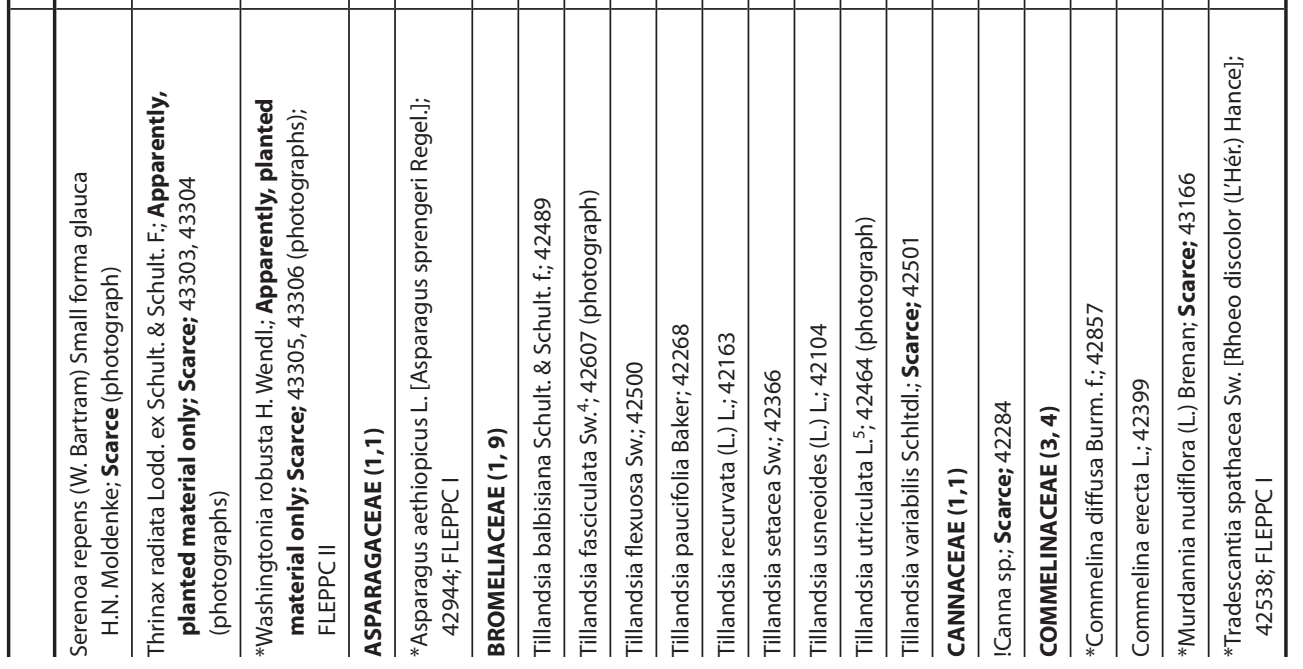




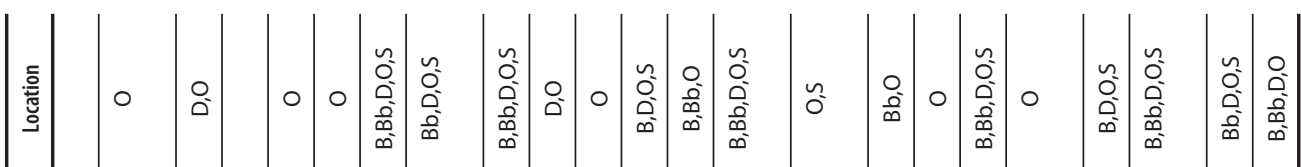

몰

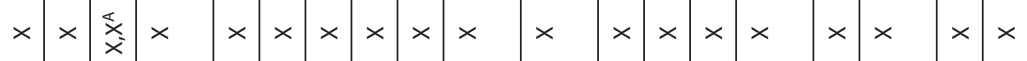

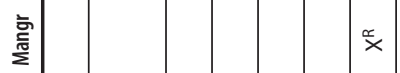

$\stackrel{\sim}{x} \quad \stackrel{\sim}{x}$

$\frac{\bar{n}}{\stackrel{5}{\frac{5}{2}}}$

$\underset{\times}{\times}$

$\stackrel{\substack{x \\ \times}}{\stackrel{x}{x}}$

竞

\begin{tabular}{l|l|l}
$\times$ \\
$\times$
\end{tabular}$\quad \underset{x}{x}$

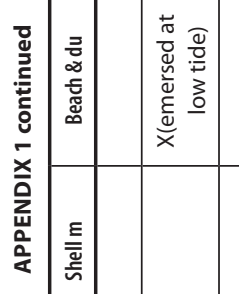

1

$\stackrel{\substack{x \\ x}}{x}$

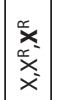

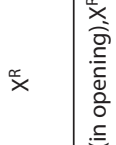

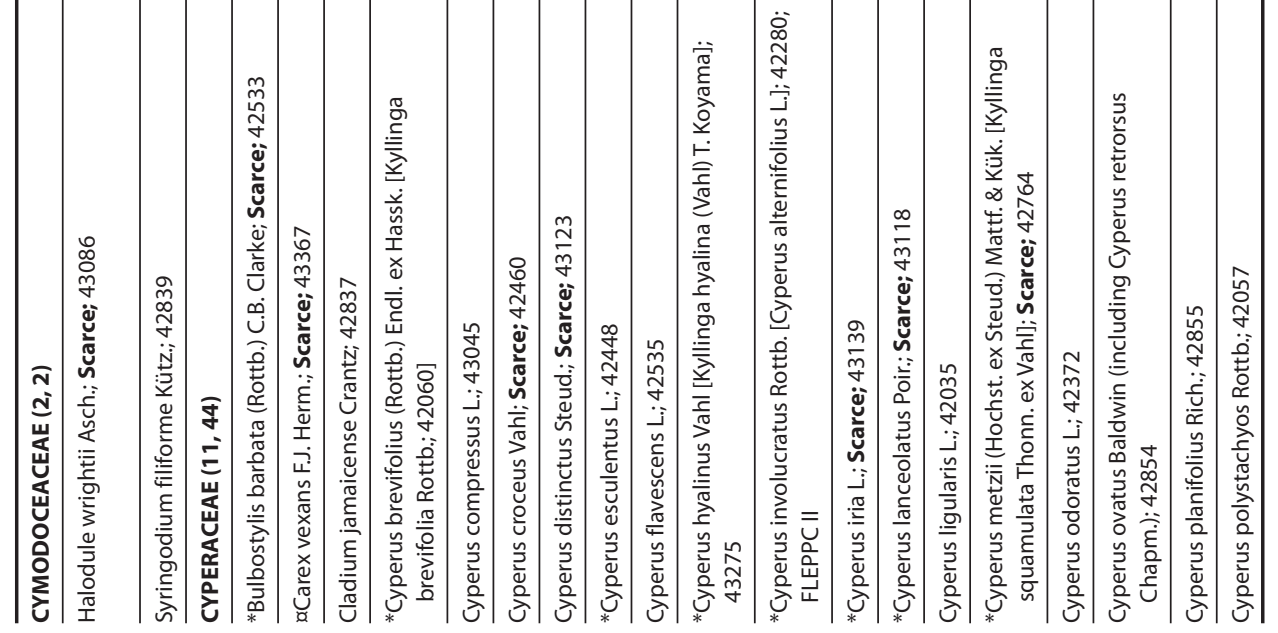




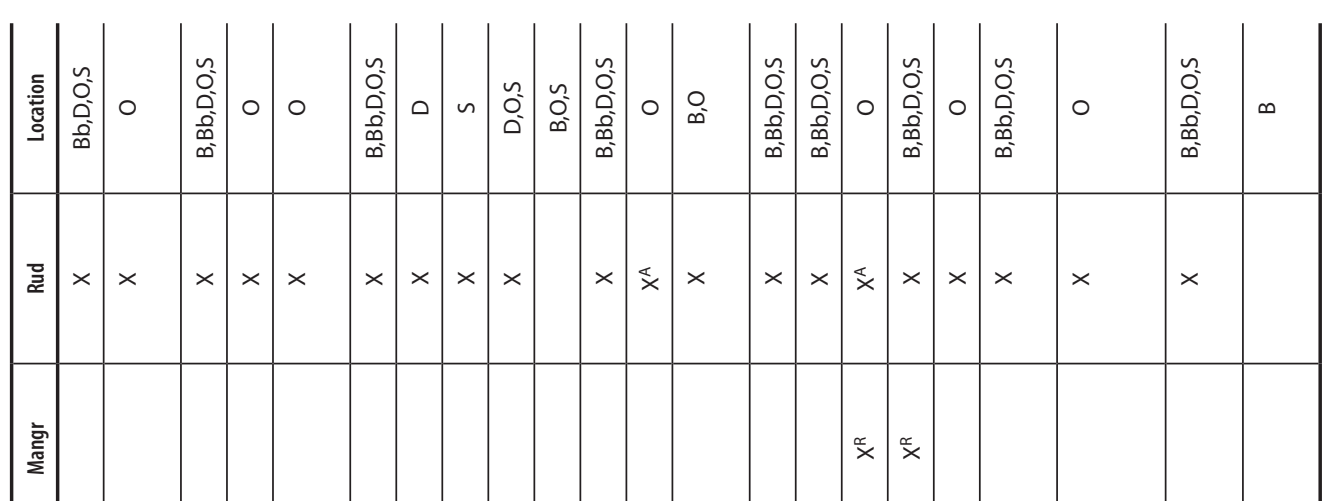

旁

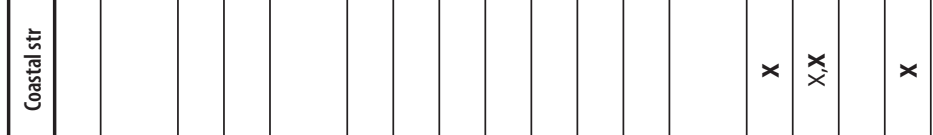

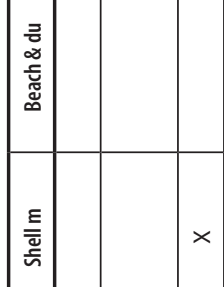

产

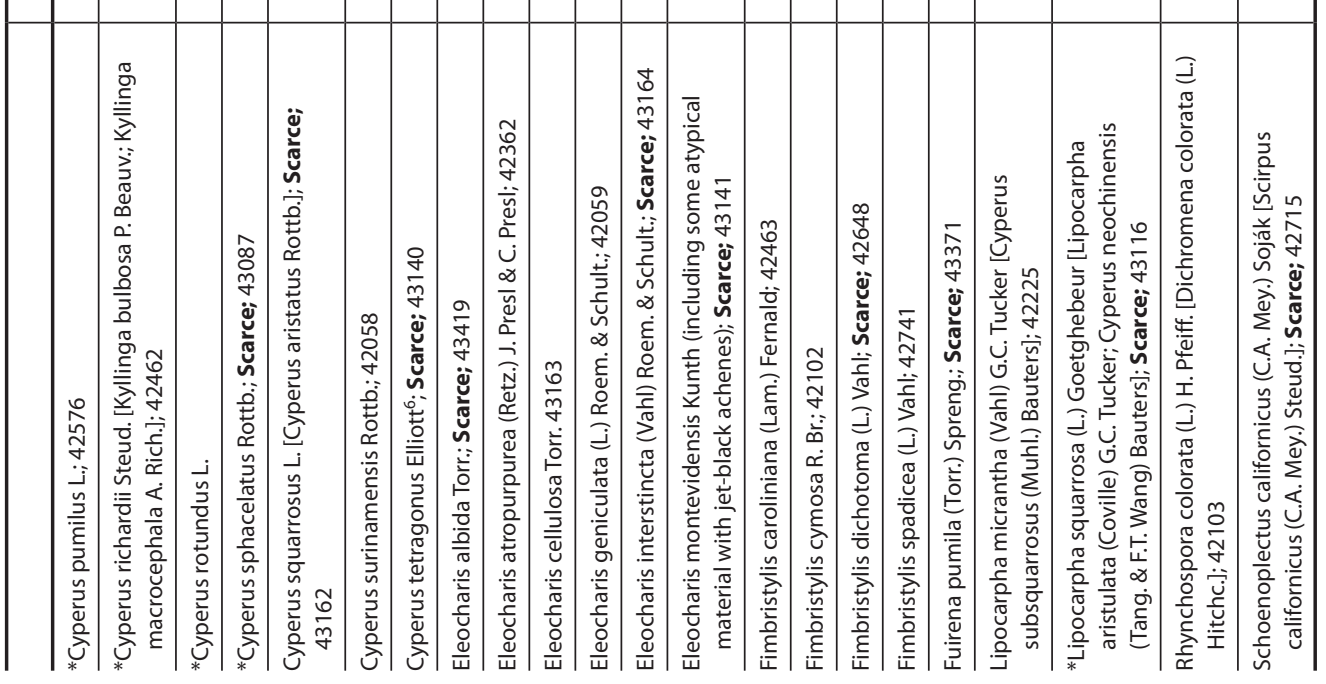




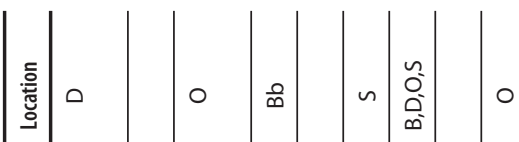

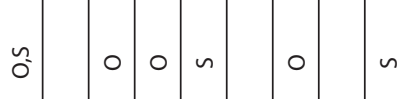

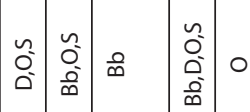

를

$\times \quad \times$

$\times \quad \times \times$

$\times \times \times$

畗

$\stackrel{\varkappa}{x}$

$\underset{\substack{x \\ x}}{x}$

产

章

$\times$

$\times \quad \times$



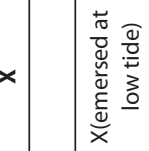

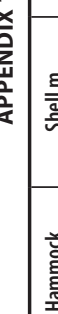

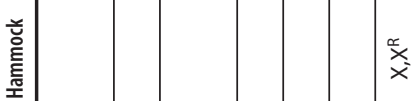

$\tilde{x} \quad \tilde{x} \underset{x}{\tilde{x}} \quad \begin{gathered}\tilde{x} \\ \tilde{x} \\ \tilde{x} \\ \dot{x} \\ x\end{gathered}$
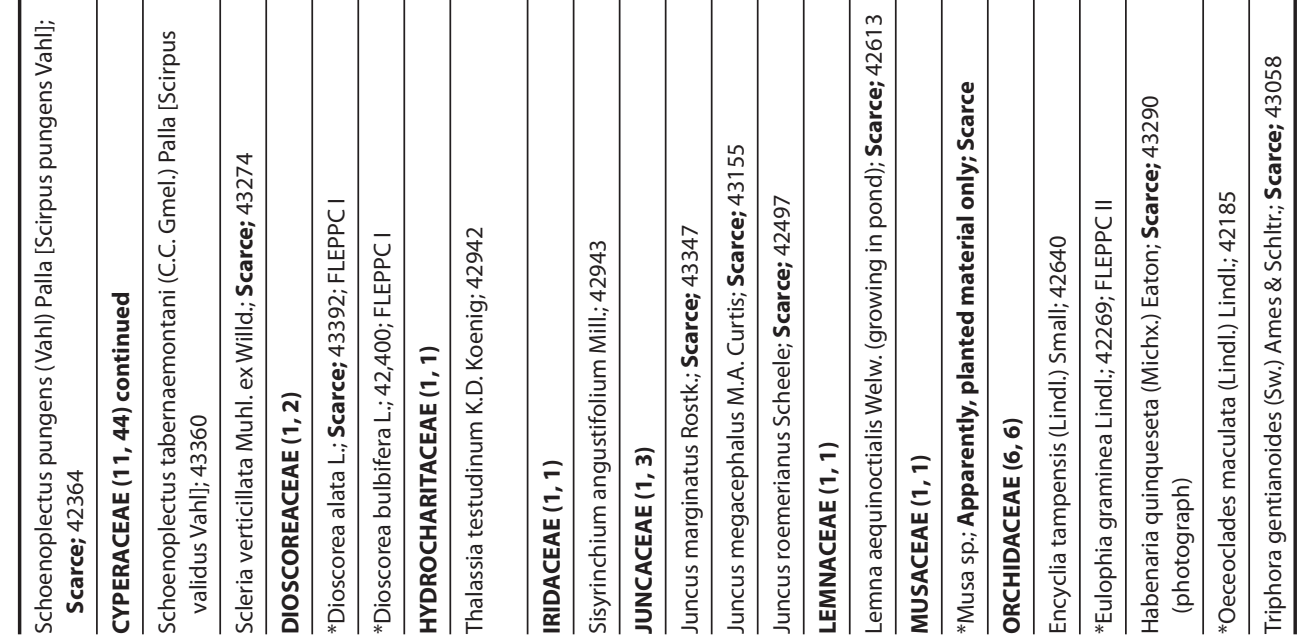


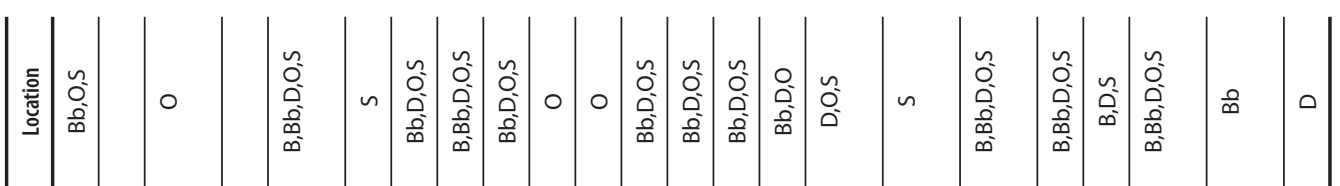

흘

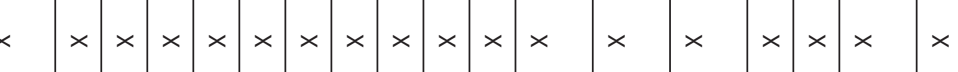

产

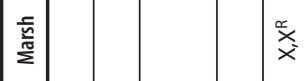

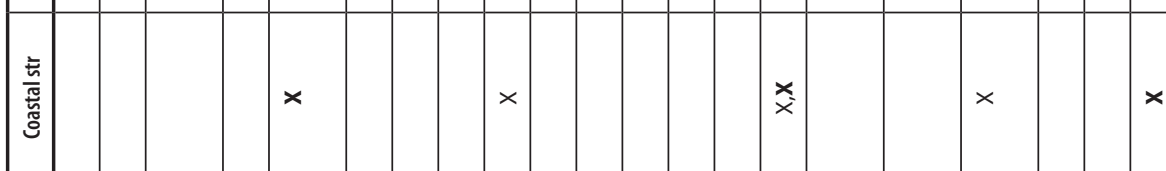

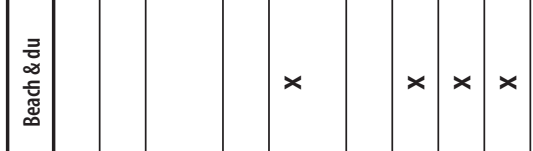

$\frac{\underline{\underline{E}}}{\underline{\underline{\underline{\omega}}}}$

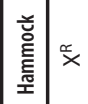

$\stackrel{\infty}{x} \stackrel{⿱}{x} \quad \stackrel{⿱}{x}$

$\stackrel{\sim}{x}$

$\stackrel{\infty}{x}$

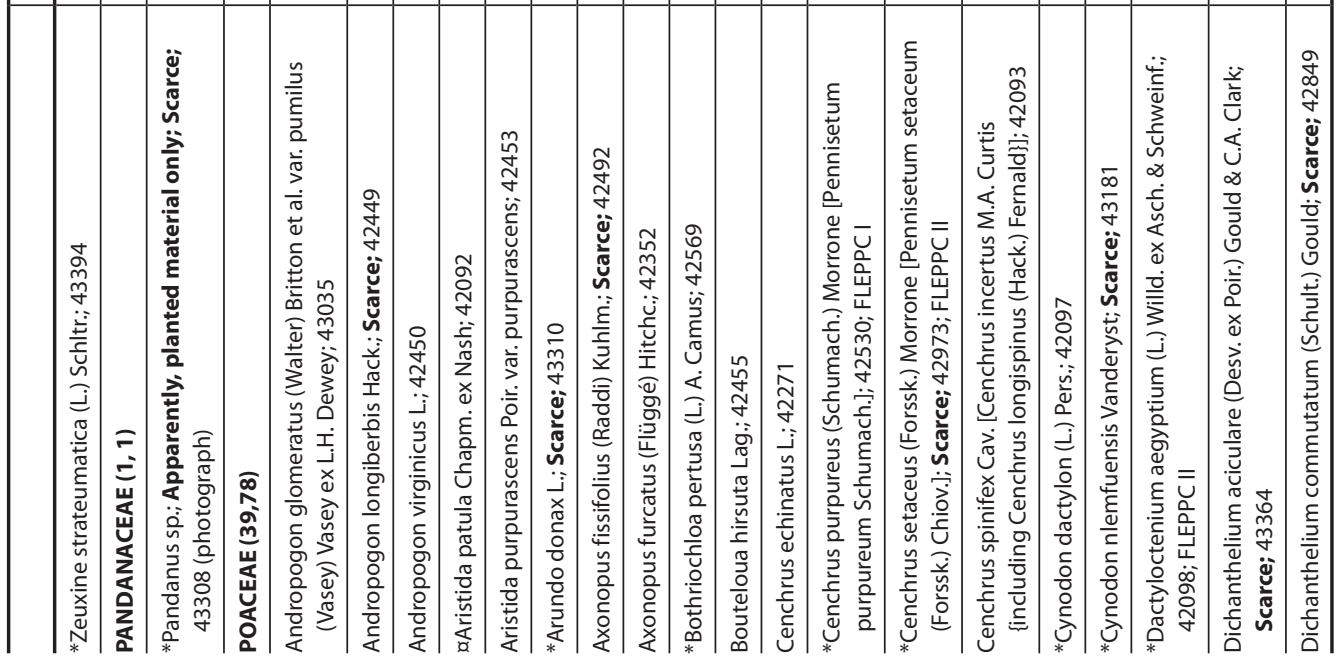




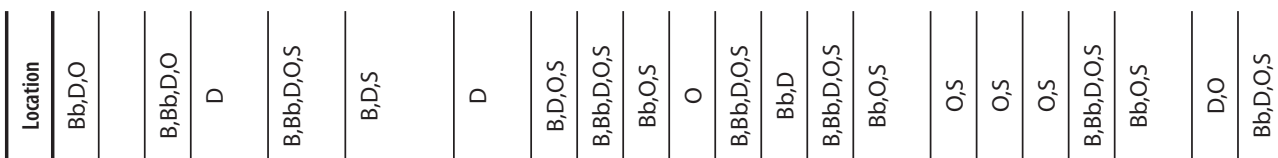

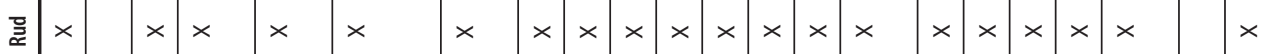

i

更

畜

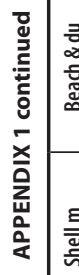

产

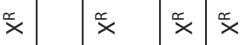

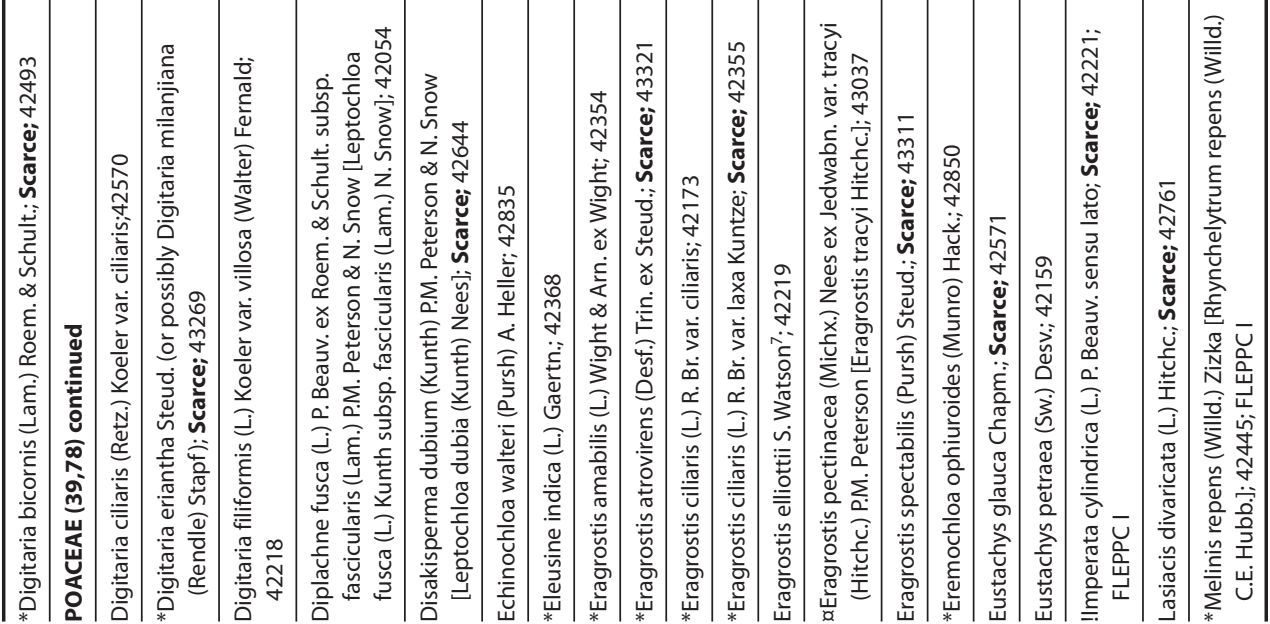




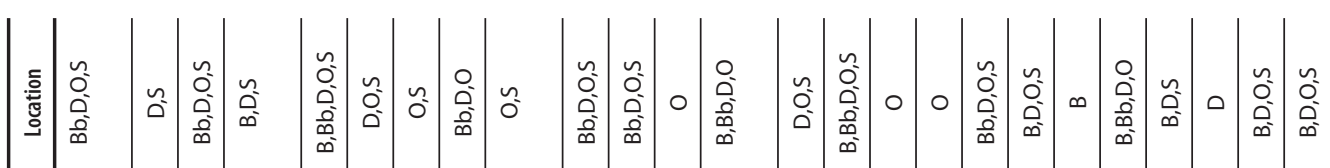

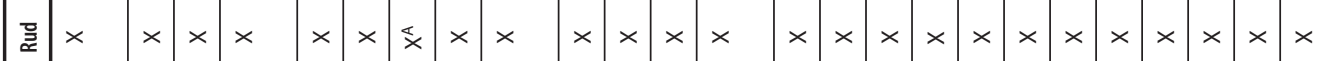

厗 $\stackrel{\infty}{x}$

高

$\sqrt{\mathbf{n} \times x} \times$

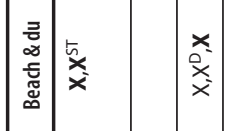

高

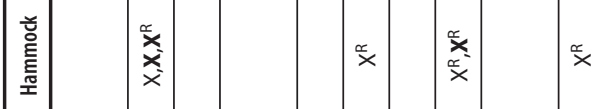

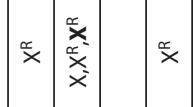

$\stackrel{\infty}{x}$

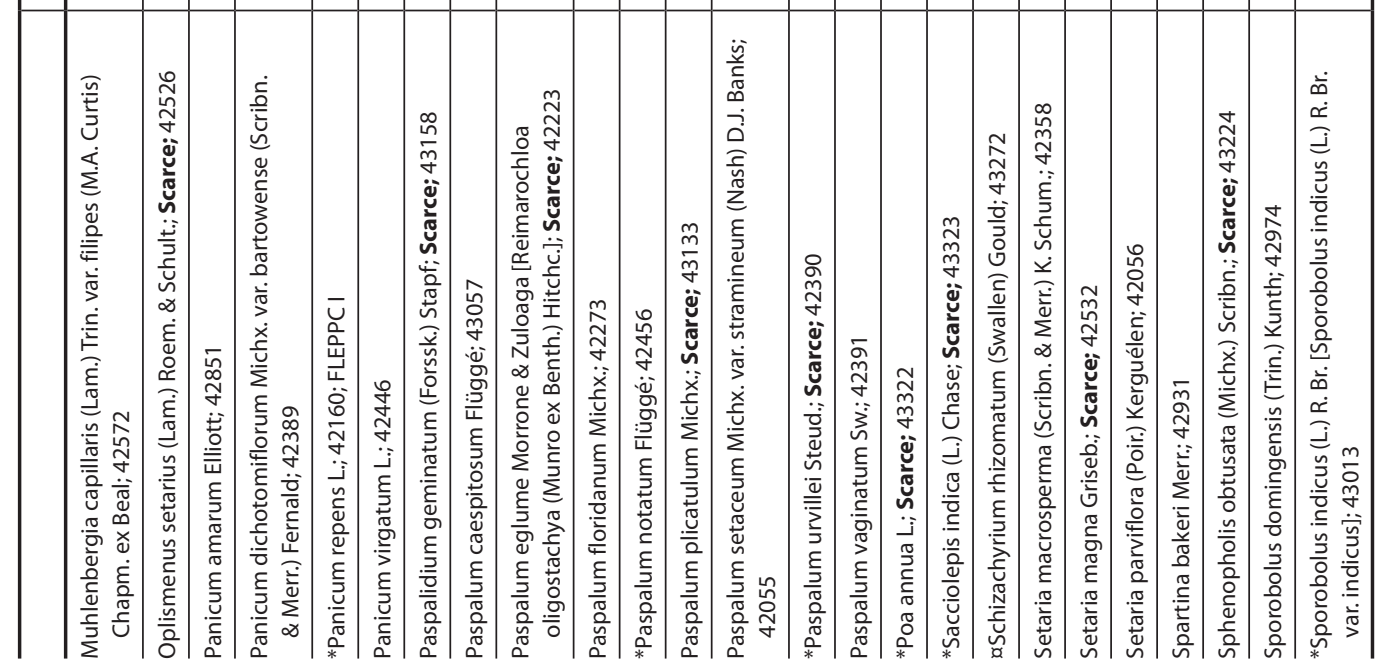




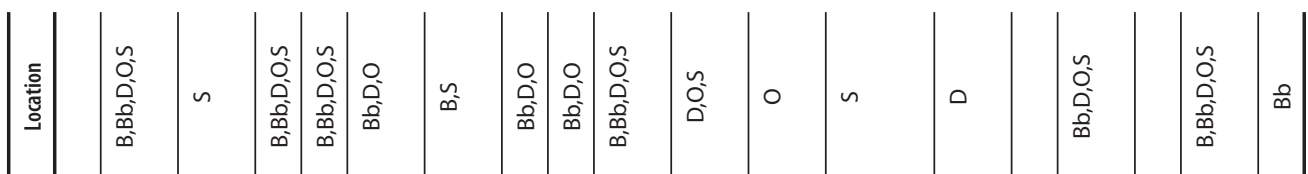
플 힌
$\frac{0}{2}$

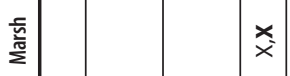

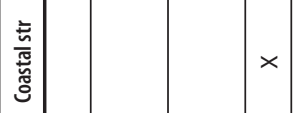

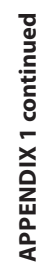

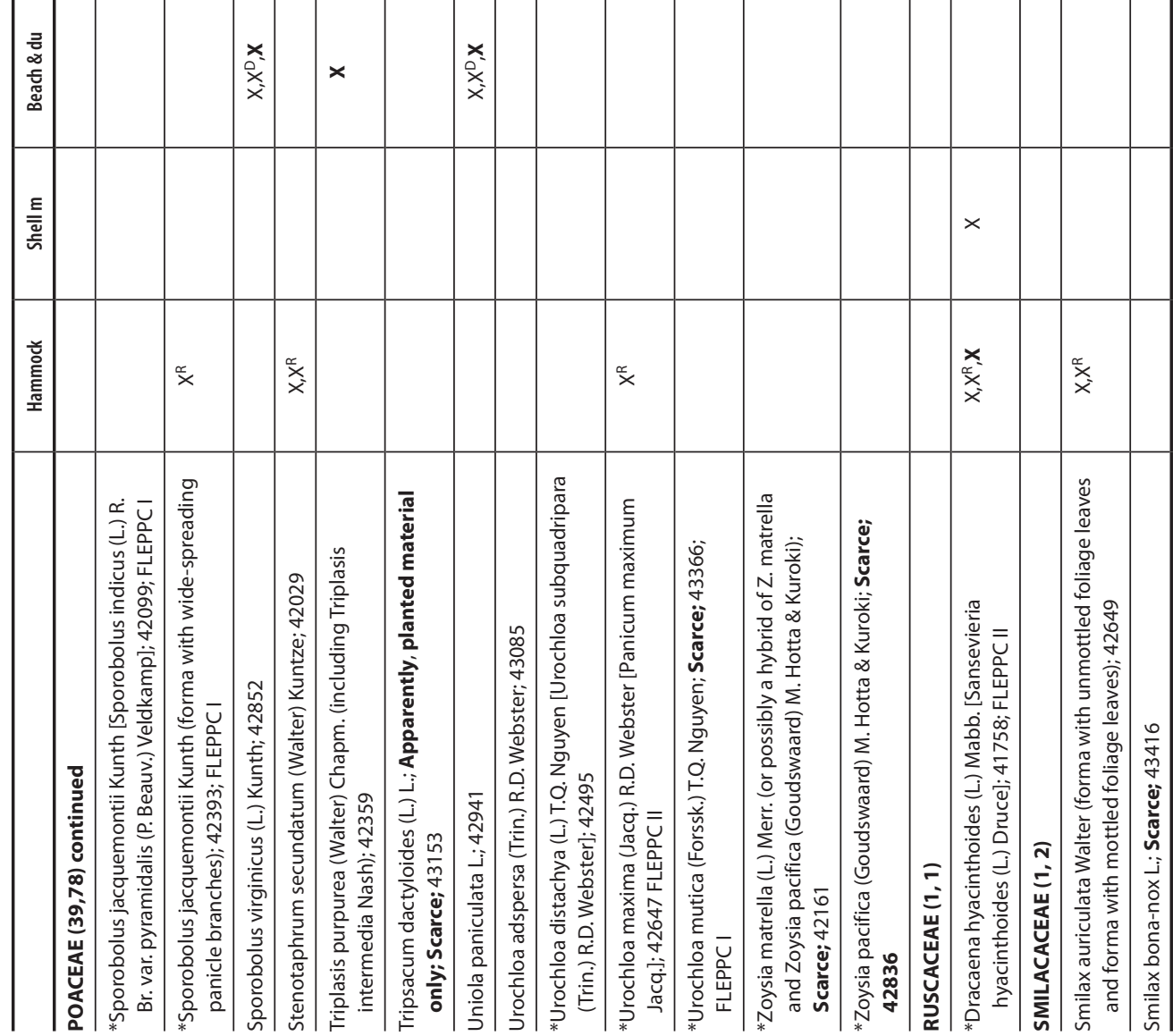




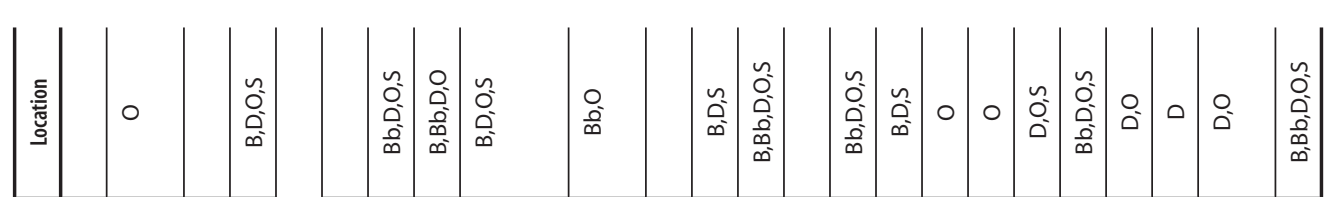

힌 $x$

i

$\underset{\substack{x \\ \times}}{\stackrel{x}{x}}$

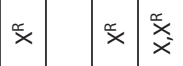

$\underset{\substack{x \\ x}}{\stackrel{x}{x}}$

$\frac{\frac{5}{5}}{\frac{5}{c}}$

$\times$

$\stackrel{x}{\times}$

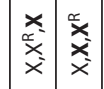

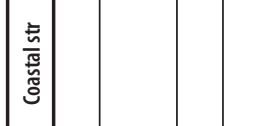

$\times \quad \underset{x}{x}$

$\times$

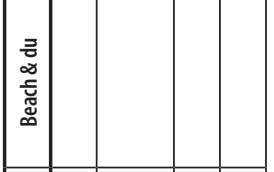

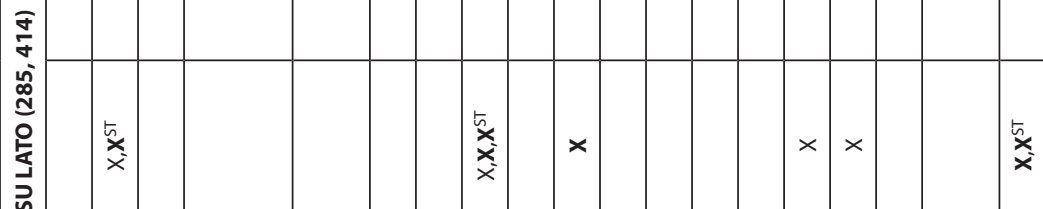

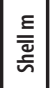

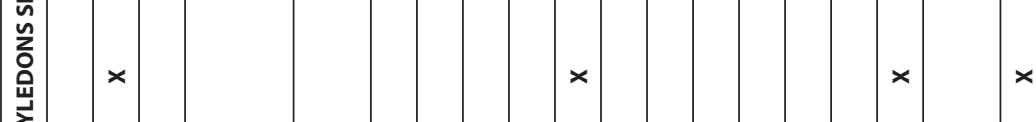

产

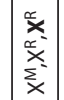

$\underset{x}{\stackrel{\infty}{x}} \underset{x}{x}$

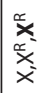

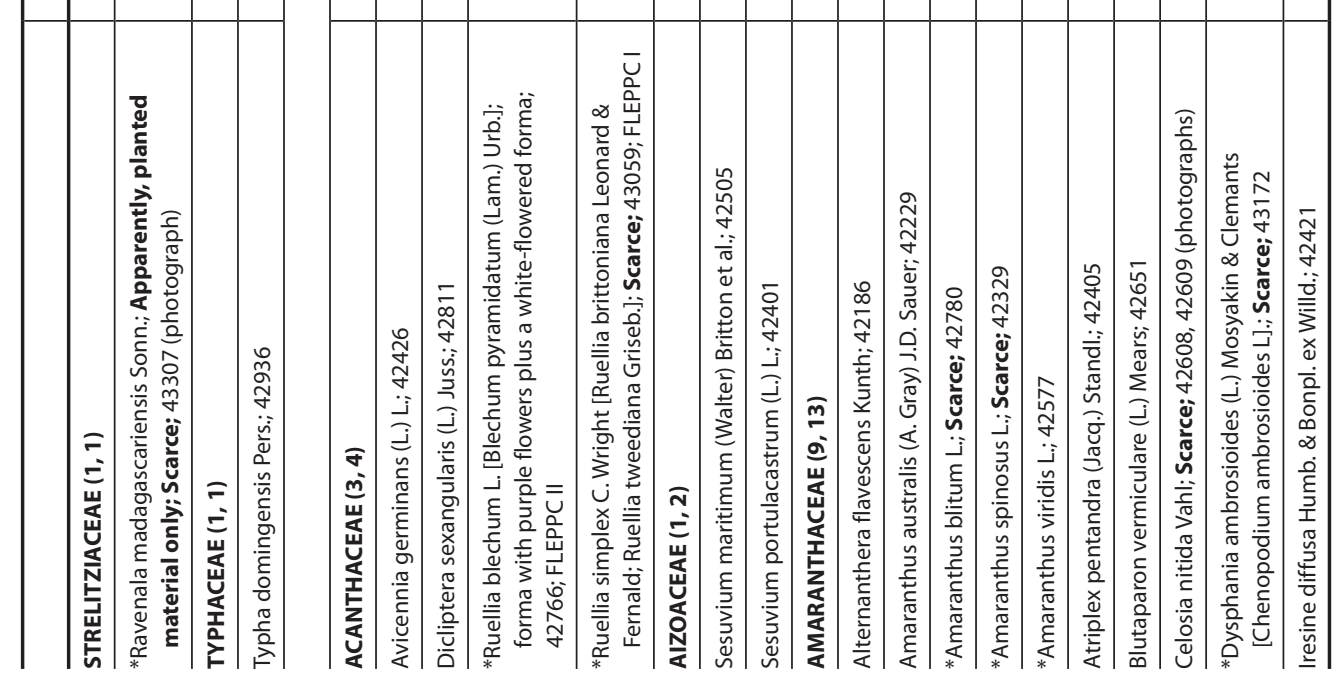




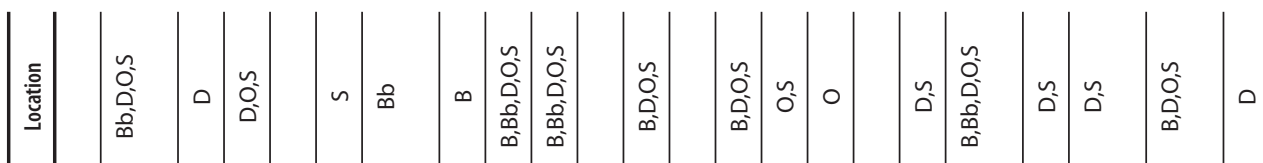

ב

$\begin{array}{lllll} & \times & \times & \times & \end{array}$

\begin{tabular}{ll|l|l|}
\hline & \\
\hline
\end{tabular}

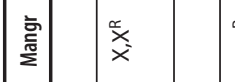

\begin{tabular}{l|l|l|}
$\stackrel{\infty}{x}$ & $\stackrel{x}{x}$ & $\stackrel{x}{x}$ \\
$\stackrel{x}{x}$
\end{tabular}

$\stackrel{\infty}{\stackrel{\infty}{x}} \stackrel{\stackrel{\infty}{x}}{\stackrel{x}{x}}$

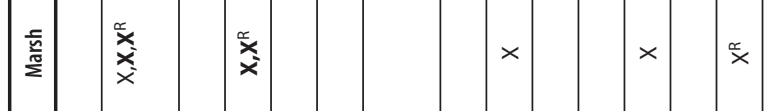

言

$\underset{x}{\times}$

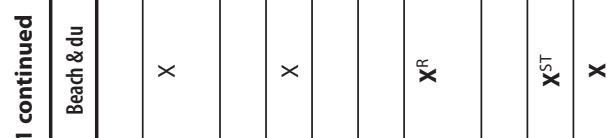

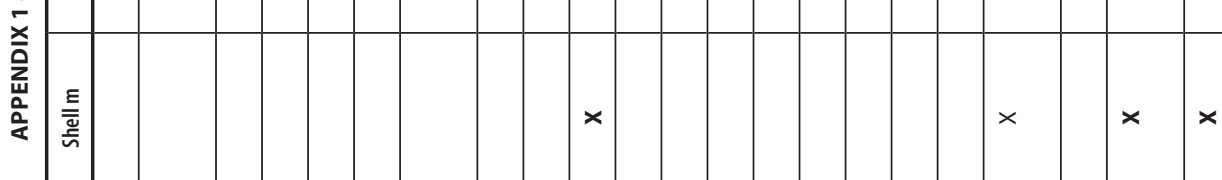

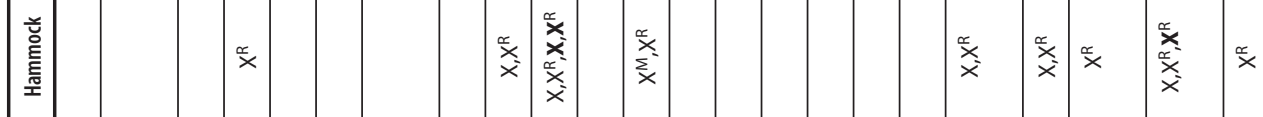

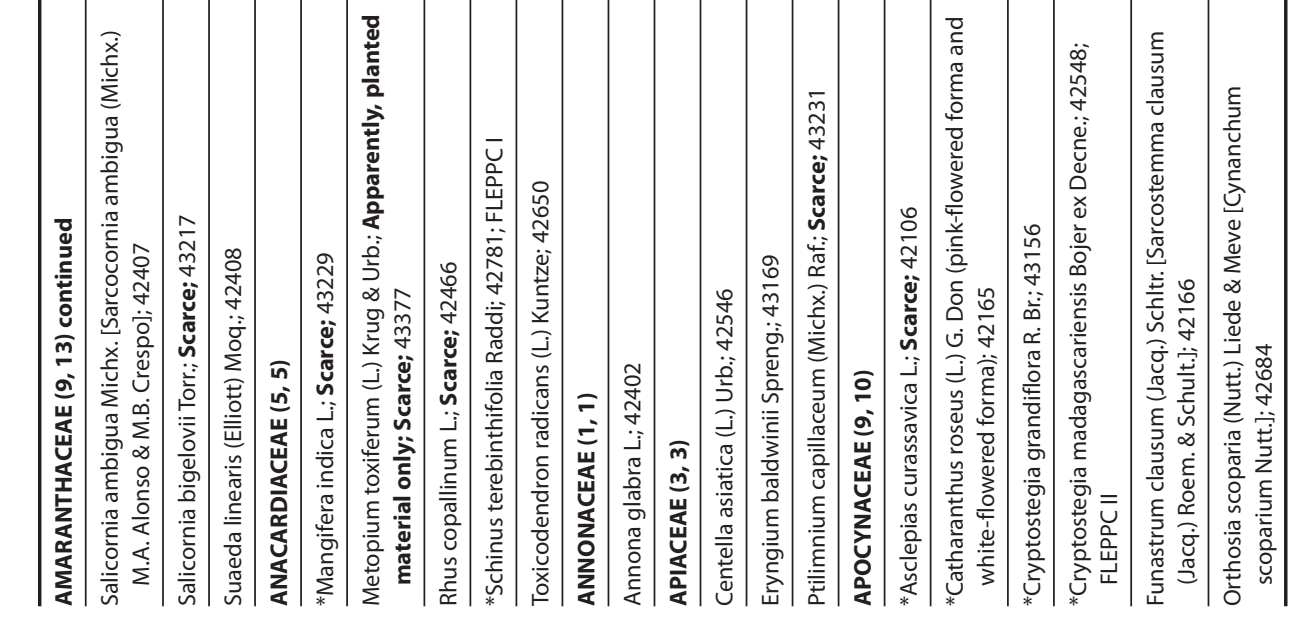




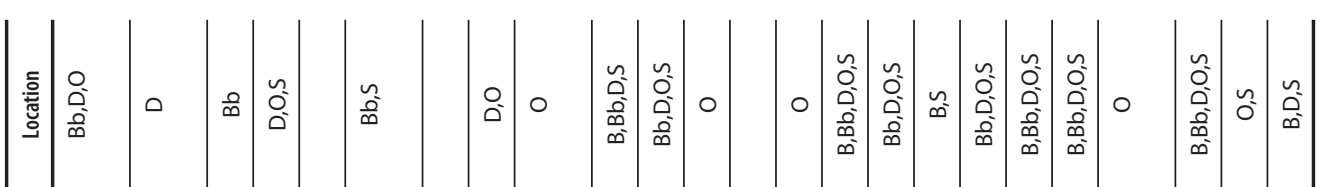

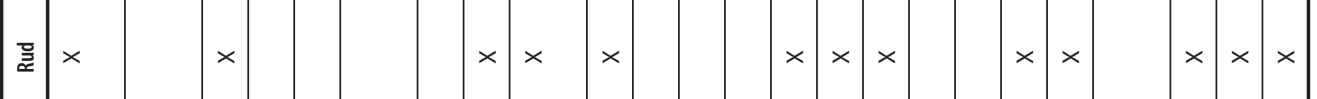

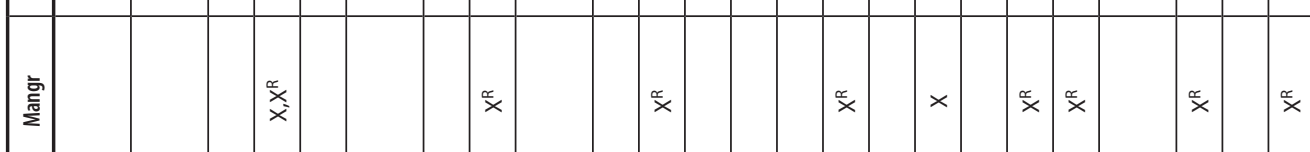

高

$\times \quad \quad \times \quad \times \underset{x}{\stackrel{x}{x}} \quad \underset{x}{x}$

离

$\underset{\times}{\stackrel{x}{\times}} \times \quad \quad \quad \underset{\times}{\stackrel{x}{x}} \quad x$

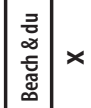

竞 $\quad \times$

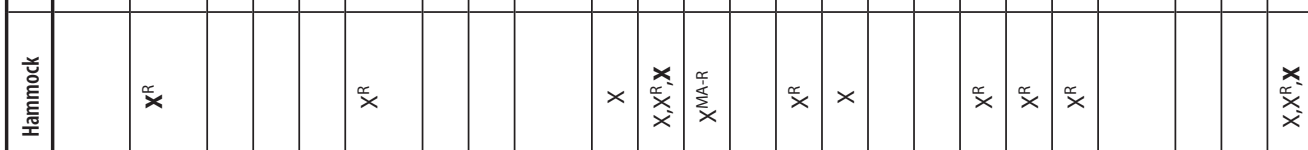

\begin{tabular}{|c|c|c|c|c|c|c|c|c|c|c|c|c|c|c|c|c|c|c|c|c|c|}
\hline 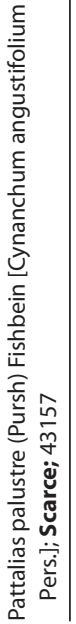 & 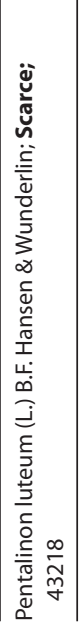 & 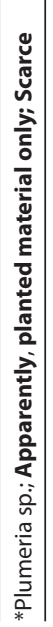 & 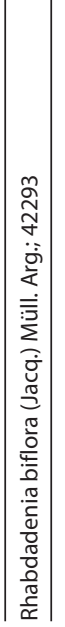 & 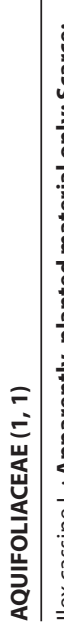 & 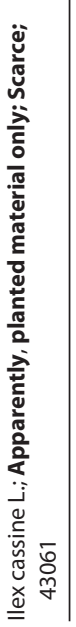 & 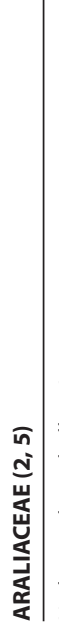 & 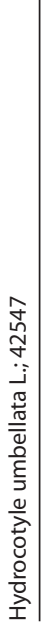 & 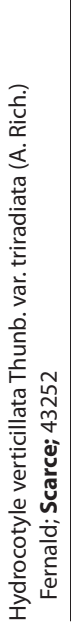 & 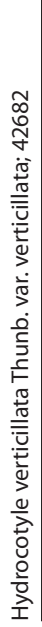 & 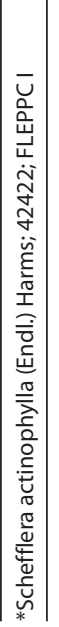 & 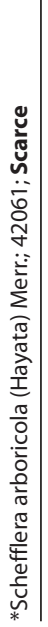 & 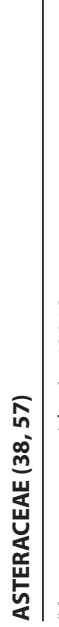 & 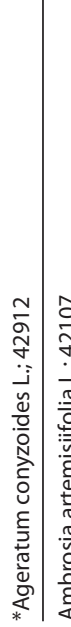 & 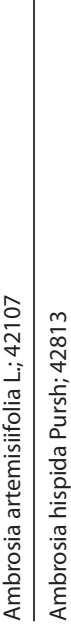 & 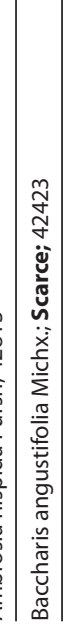 & 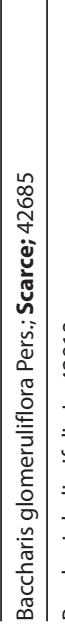 & 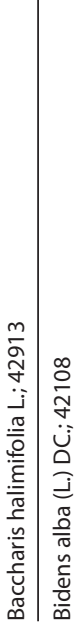 & 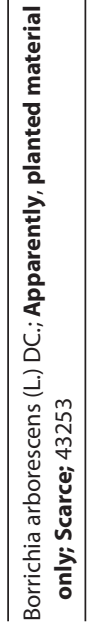 & 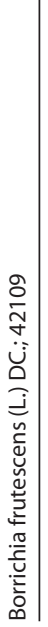 & 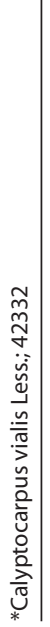 & 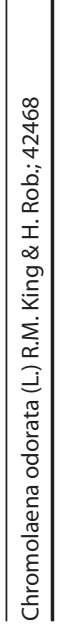 \\
\hline
\end{tabular}




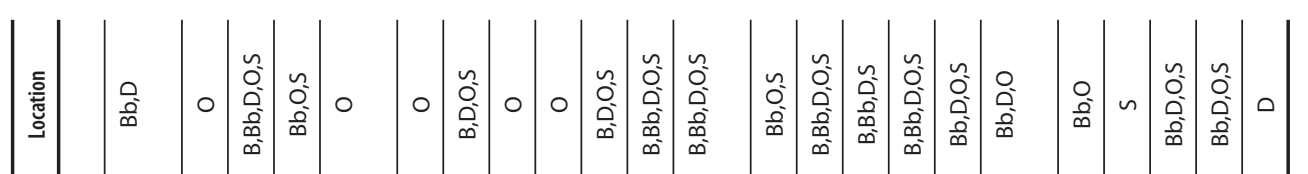

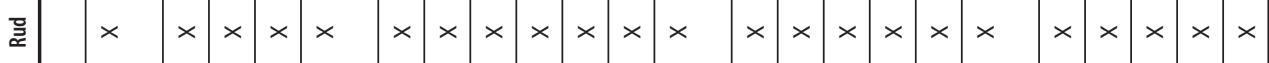

嬊

$\stackrel{\ltimes}{\times}$

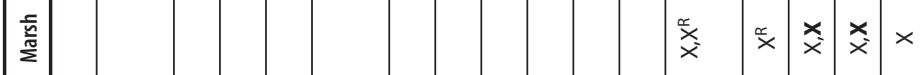

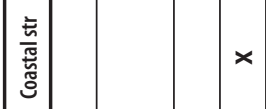

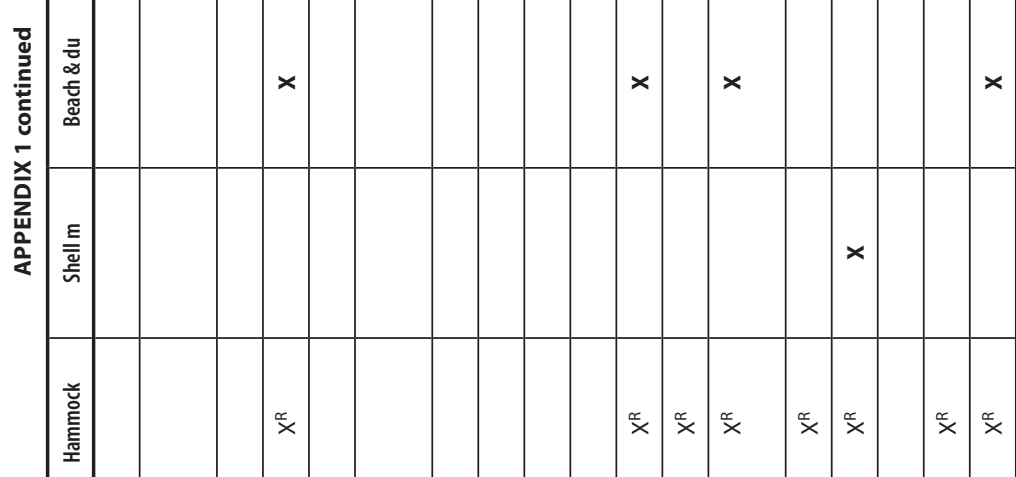

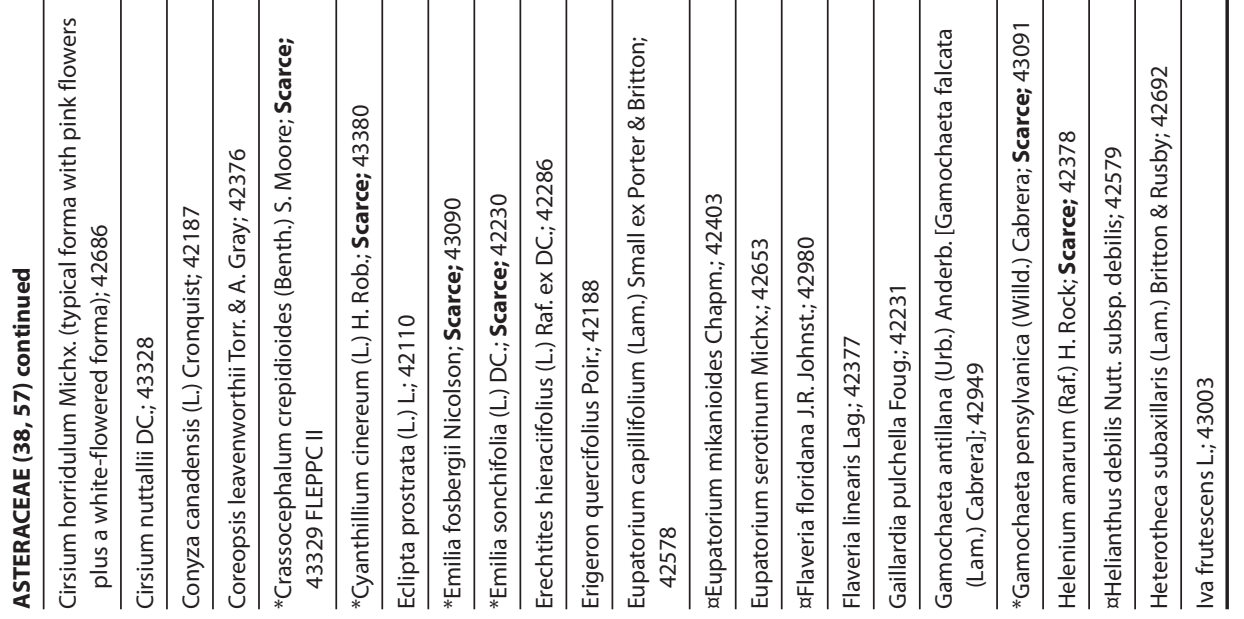




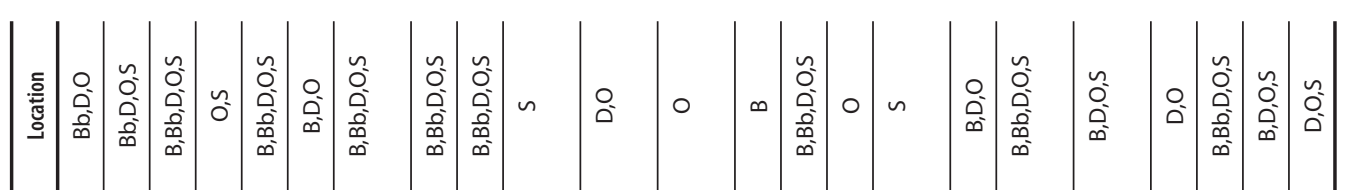
흘

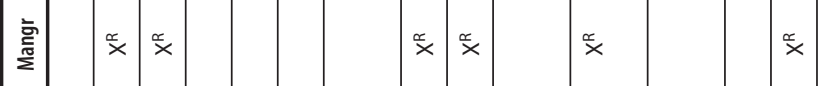

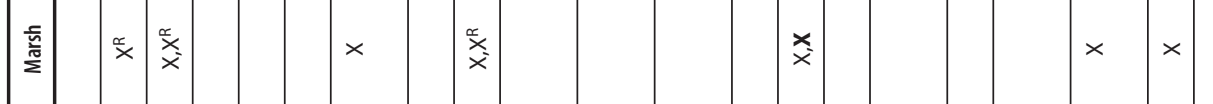

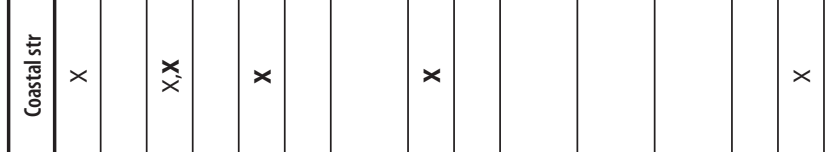

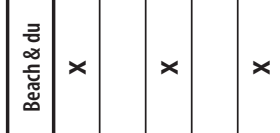

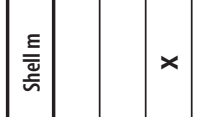

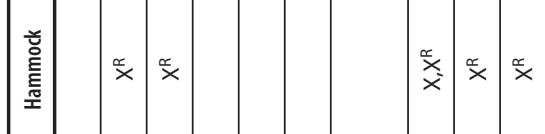

玄

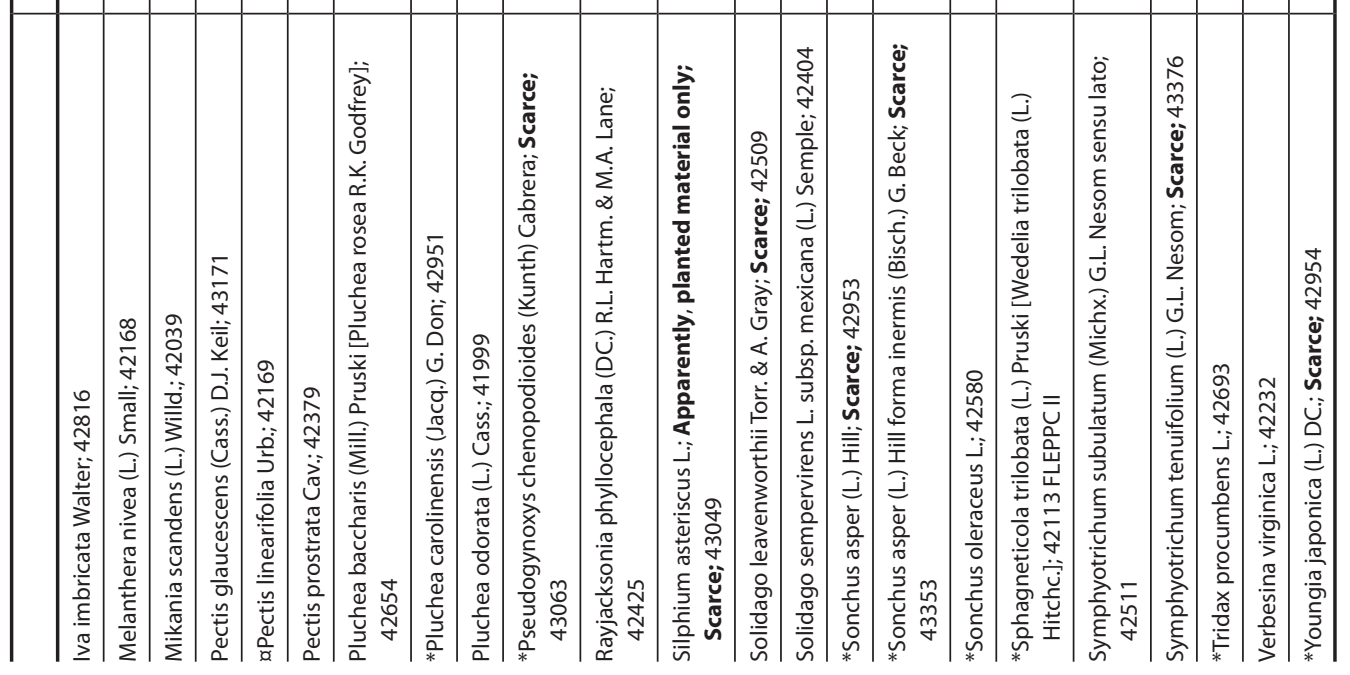




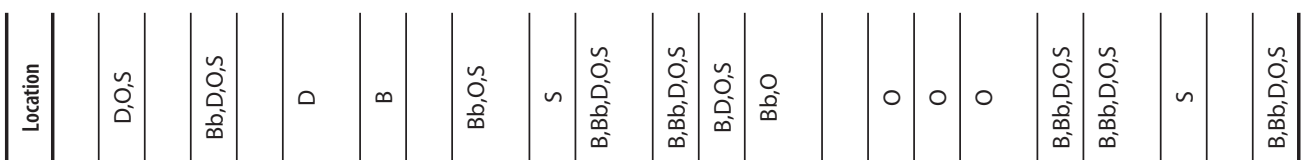
호

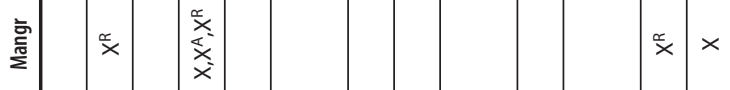
\begin{tabular}{l|l|l}
$\stackrel{\infty}{\times}$ & $\stackrel{\infty}{\times}$ & $\stackrel{\infty}{x}$
\end{tabular}

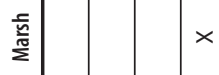

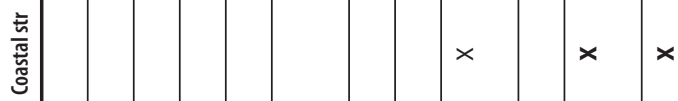

$\stackrel{x}{x} \times$

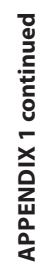

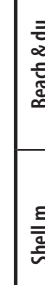

흘

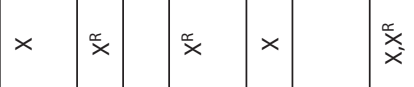

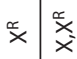

$\underset{\substack { x \\ \underset{x}{x} \\ \begin{subarray}{c}{x \\ x{ x \\ \underset { x } { x } \\ \begin{subarray} { c } { x \\ x } }\end{subarray}}{\substack{x \\ x}}$

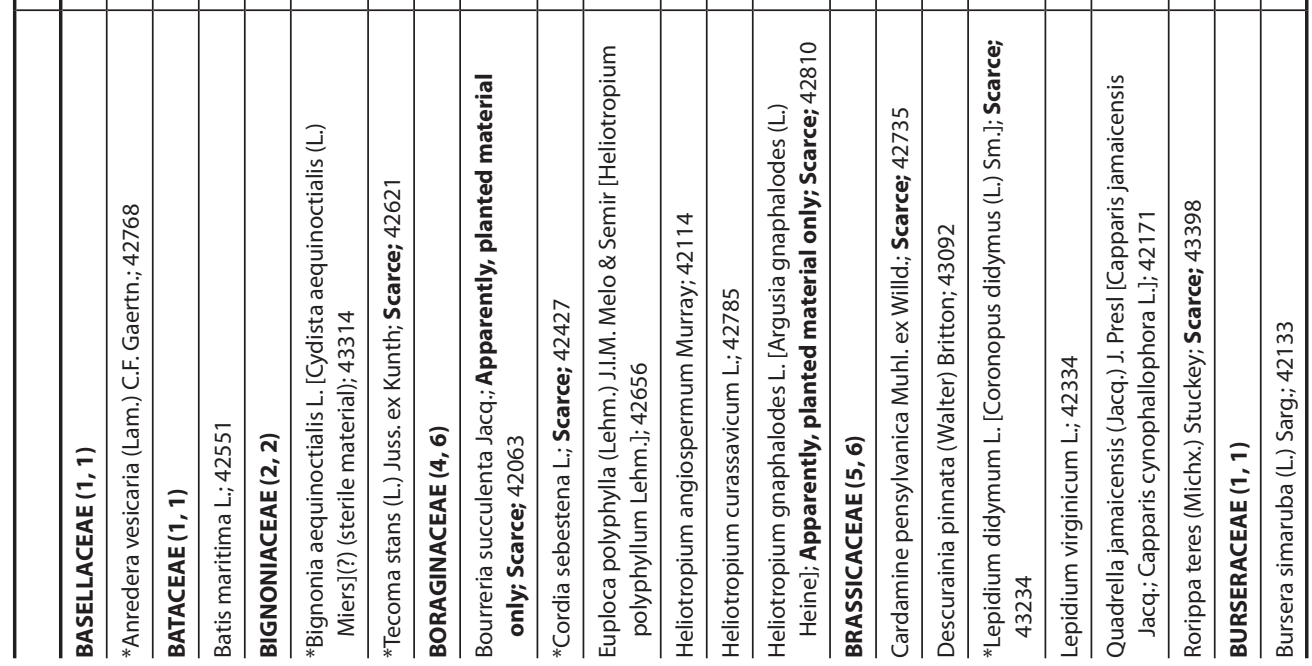



I)

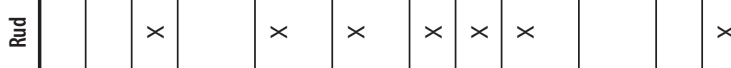

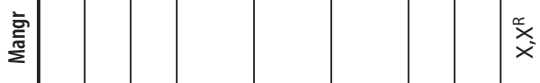

$\frac{\sqrt{5}}{\stackrel{5}{m}}$

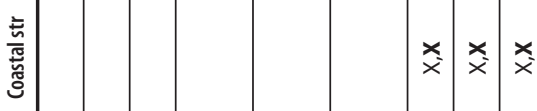

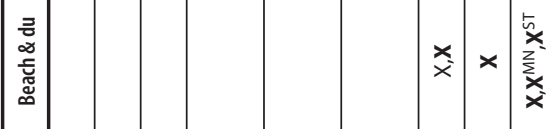

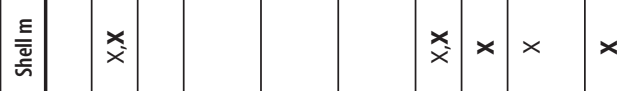

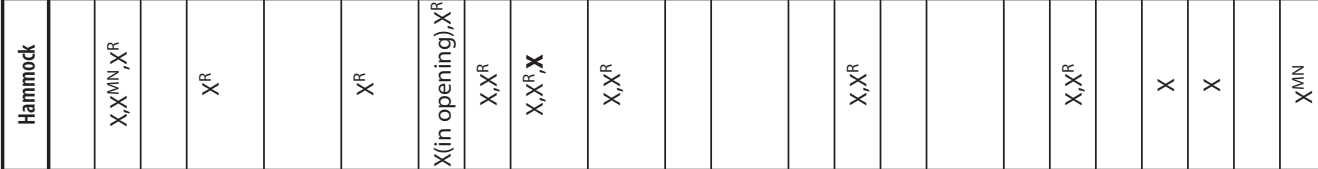

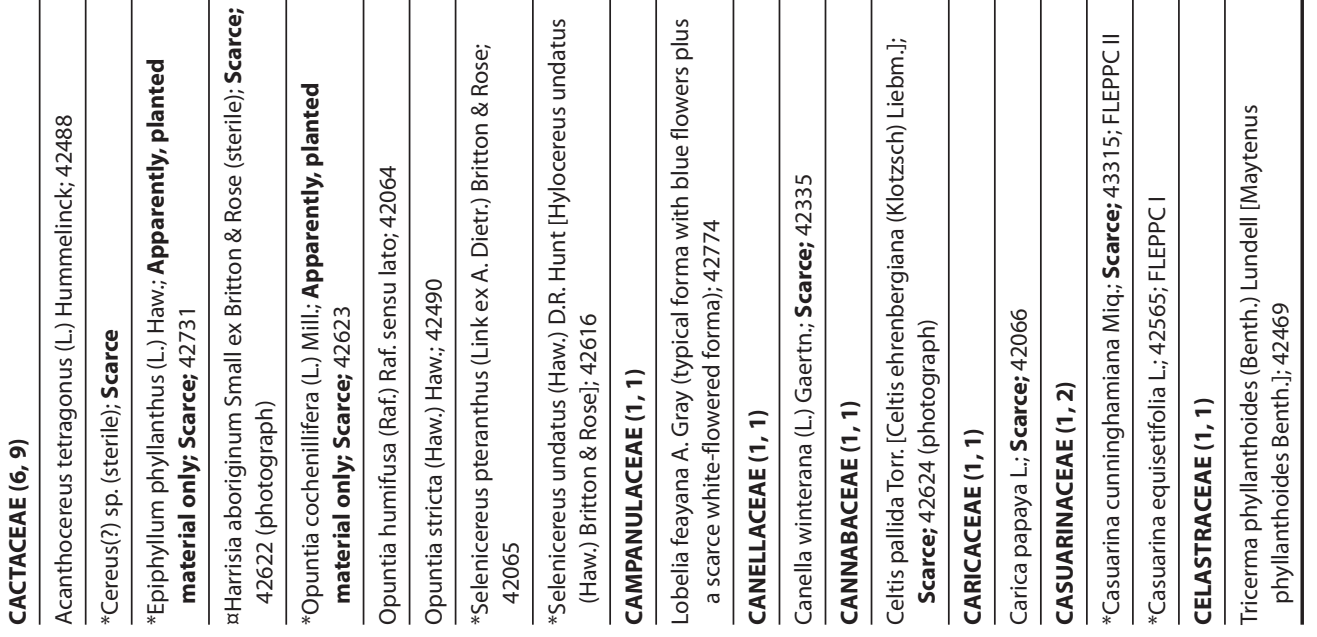




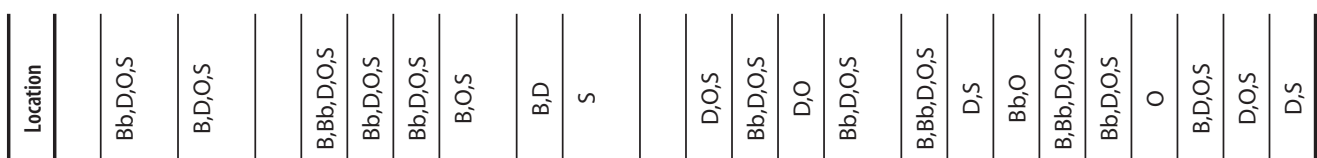

홀

$\times \times \times \times \quad \times \quad \times \quad \times \quad \times \quad \times \quad \times \quad \times$

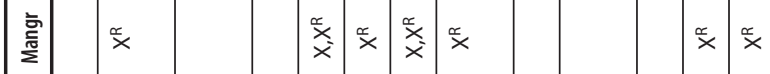

$\stackrel{\substack{x \\ x}}{x}$

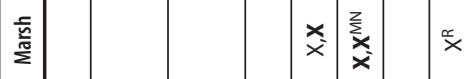

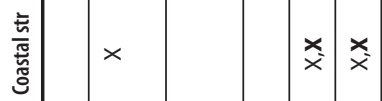

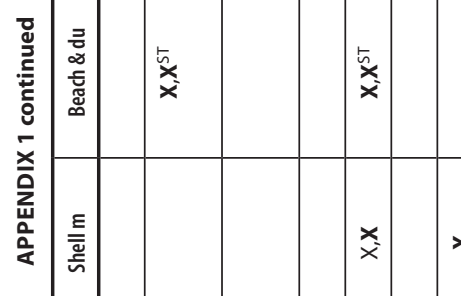

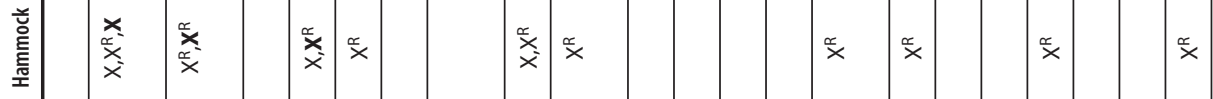

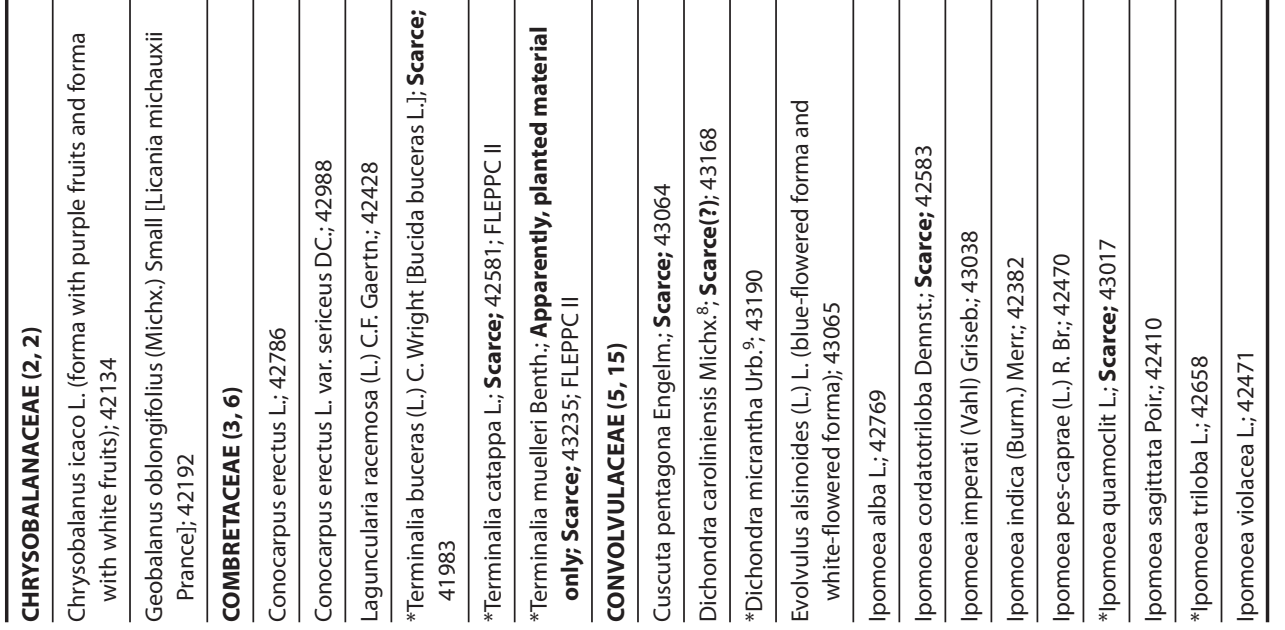




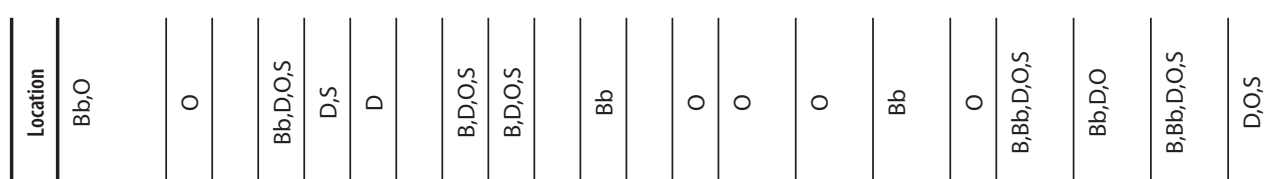

를

$\times \quad \times \quad \times \quad \times \quad \times \quad \times \quad \times$

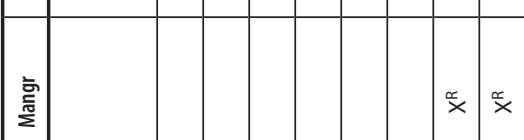

$\frac{\frac{5}{5}}{\frac{5}{2}}$

$\stackrel{\infty}{x}$

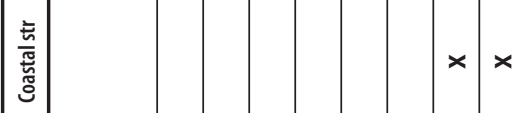

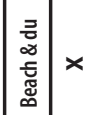

焉

$\times \times$

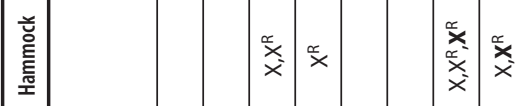

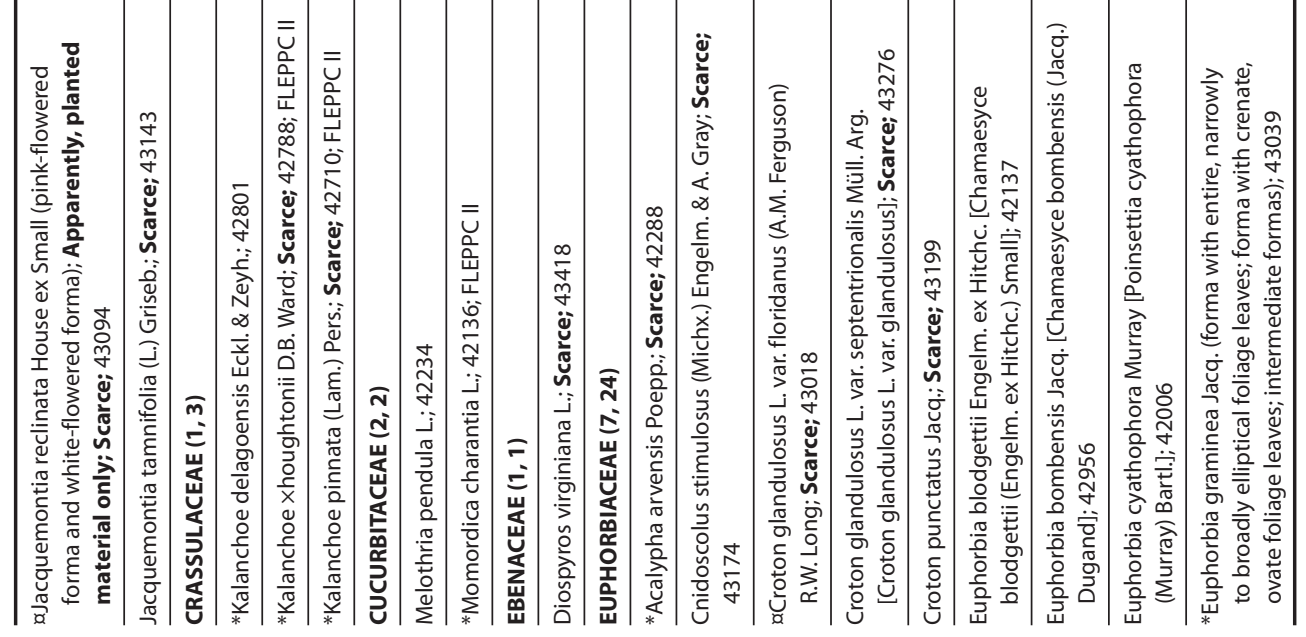




\begin{tabular}{|c|c|c|c|c|c|c|c|c|c|c|c|c|c|c|c|c|c|}
\hline 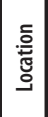 & $\mid \begin{array}{c}n \\
0 \\
0 \\
0 \\
\infty \\
\infty\end{array}$ & 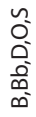 & 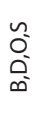 & 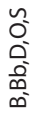 & 0 & 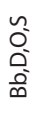 & 0 & $\begin{array}{l}0 \\
0 \\
0 \\
\infty\end{array}$ & 气̃ & $\stackrel{\circ}{\circ}$ & $\begin{array}{l}0 \\
\frac{0}{\infty}\end{array}$ & $\tilde{\Delta}$ & $n$ & $\begin{array}{l}\tilde{O} \\
0\end{array}$ & 으 & $\mid \begin{array}{c}n \\
0 \\
0 \\
0 \\
0 \\
0 \\
\infty \\
\infty \\
\infty\end{array}$ & $\overbrace{0}$ \\
\hline$\frac{\vec{z}}{2]}$ & $\times$ & $\times$ & $\times$ & $\times$ & $\times$ & $\times$ & $\times$ & $\times$ & $\times$ & $\times$ & $\times$ & & & $\times$ & $\times$ & $\times$ & $\times$ \\
\hline 히 & & & & $\stackrel{x}{x}$ & & & & & & & & & & $\stackrel{\infty}{x}$ & & & \\
\hline
\end{tabular}

$\frac{\sqrt{\frac{1}{5}}}{\frac{5}{2}}$

辛

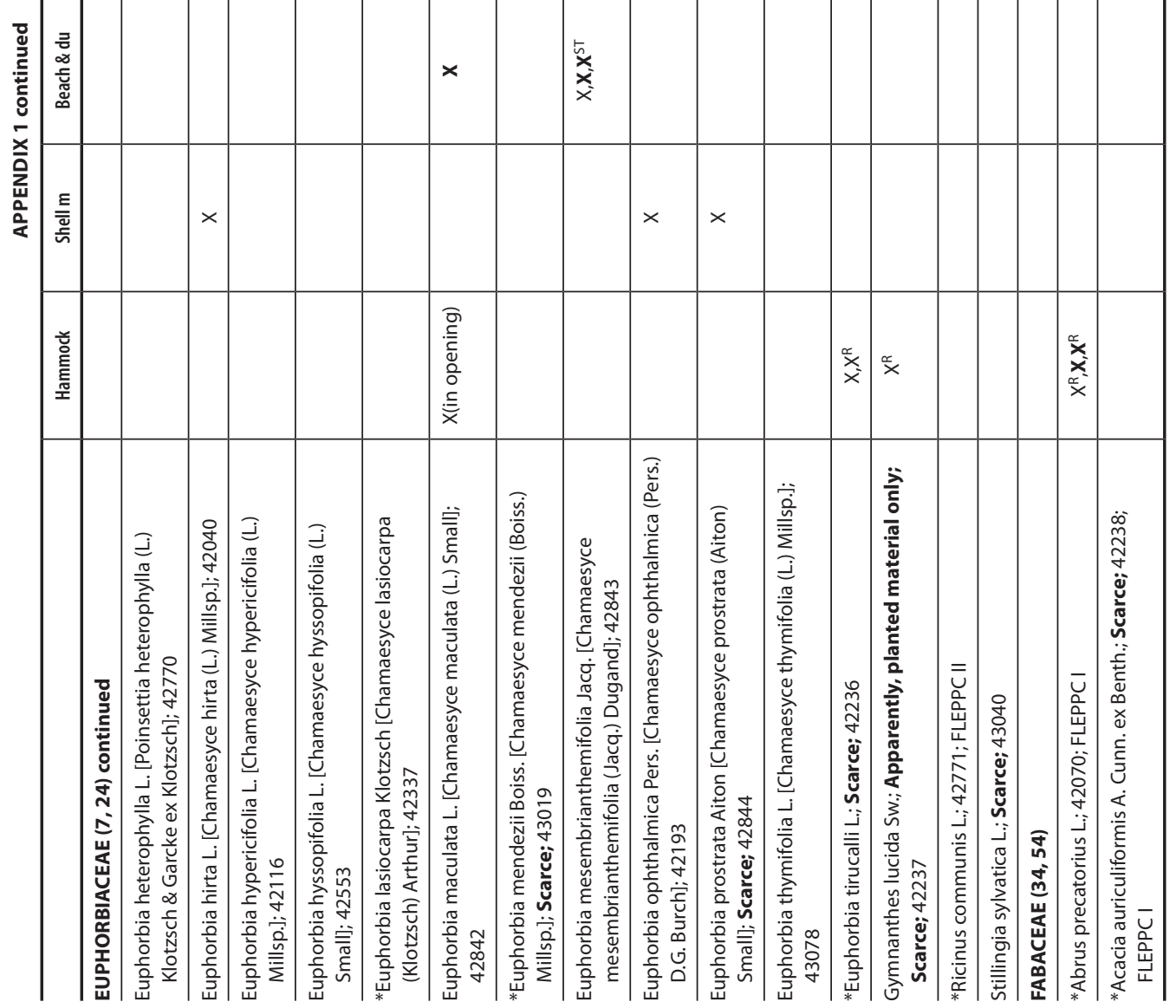




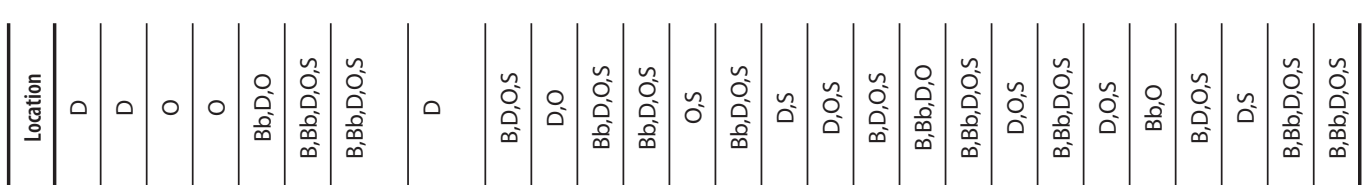

新

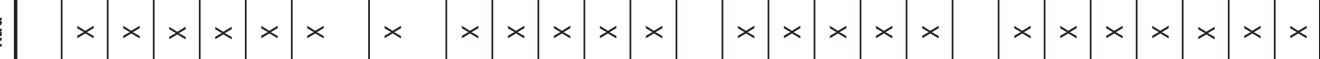

할

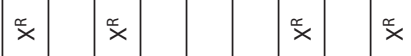

$\frac{\overline{\frac{5}{i}}}{\mathrm{i}}$

$\stackrel{x}{x}$

高

$\underset{x}{\stackrel{x}{x}} \underset{x}{\stackrel{x}{x}}$

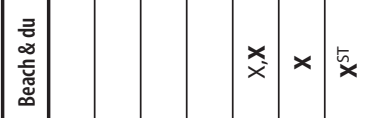

言

$\times \quad \times$

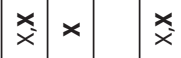

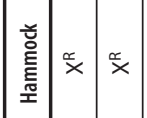

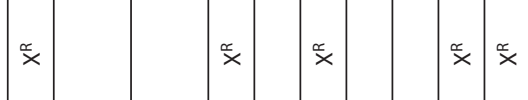

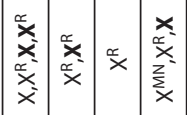

$\stackrel{\substack{x \\ x}}{x}$

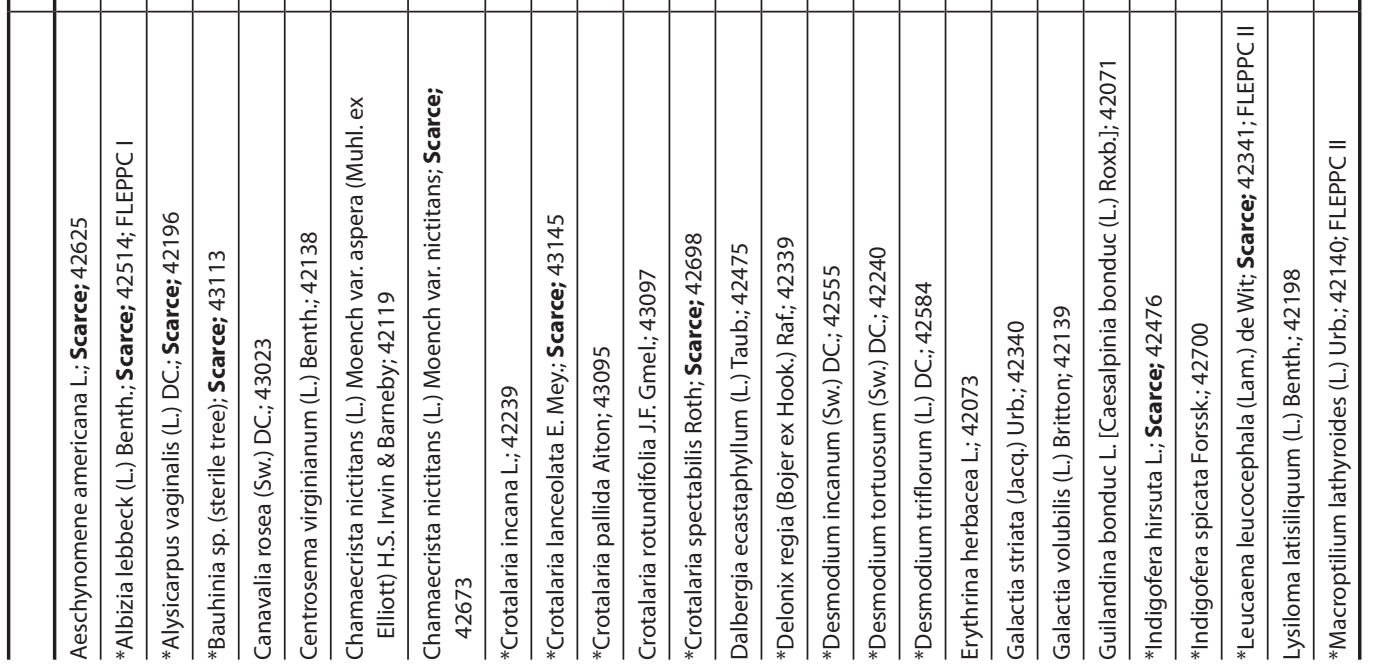




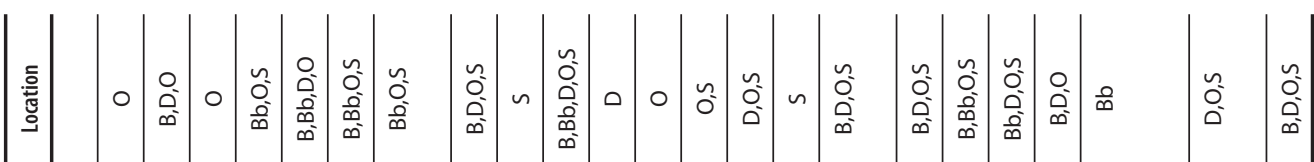

产

$\times \times \times \times \times \times \times$

$\times \times \times \times \times \times \times \quad \times \quad \times \quad \times \quad \times \quad \times \quad \times$

$\times \quad \times$

흔

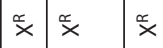

高

$\stackrel{\infty}{x}$

$\underset{\frac{5}{5}}{\frac{5}{5}}=\quad \quad \quad x$

$\times \underset{x}{x}$

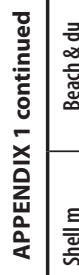

흘

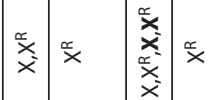

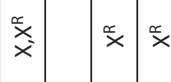

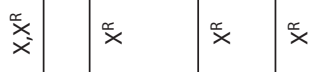

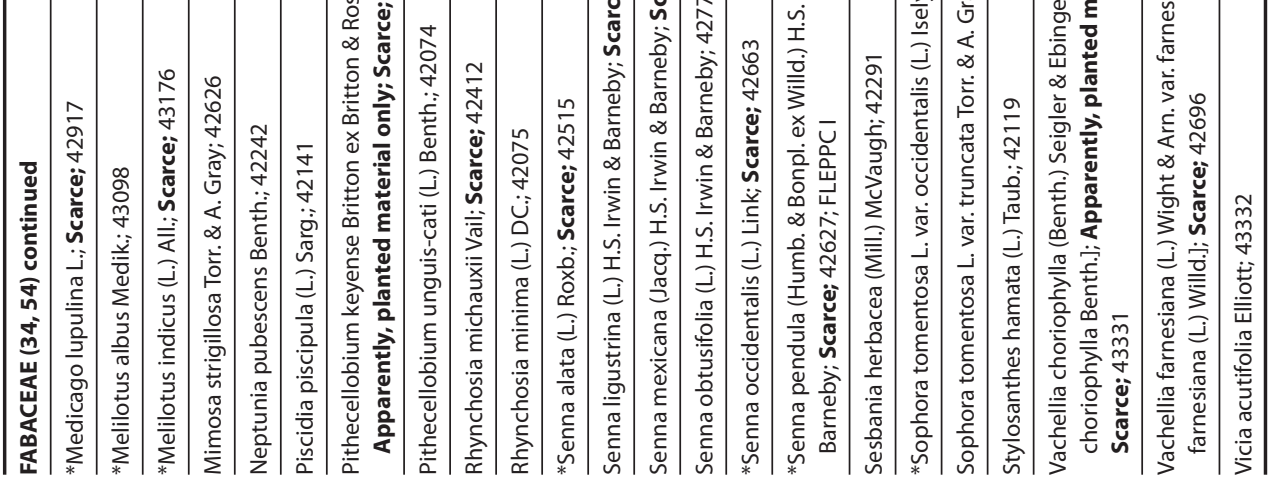




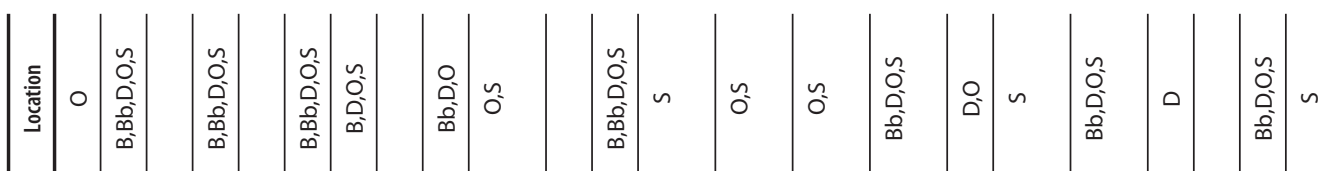

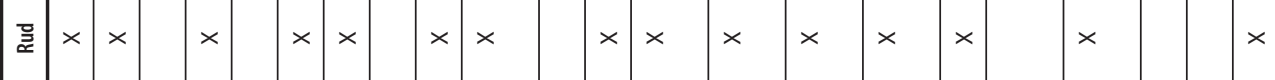

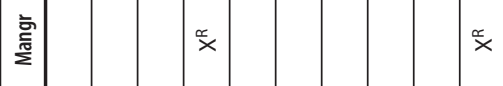

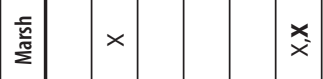

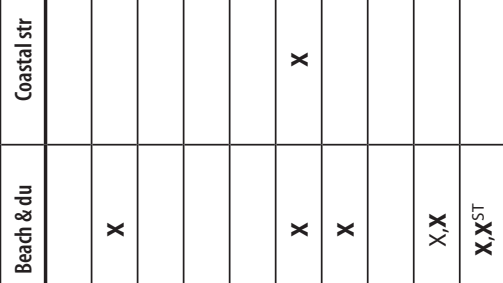

$\frac{\underline{E}}{\bar{\Xi}}$

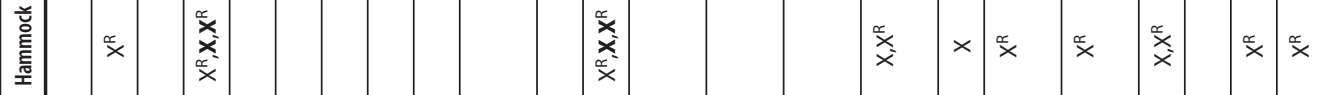

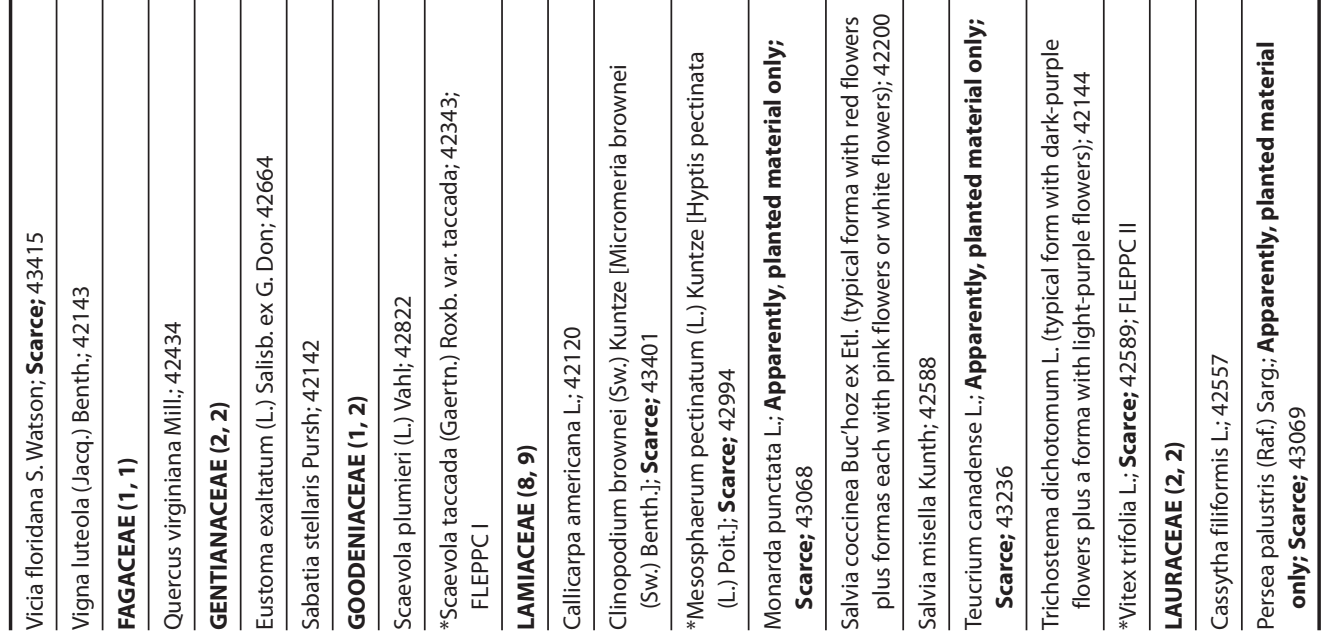




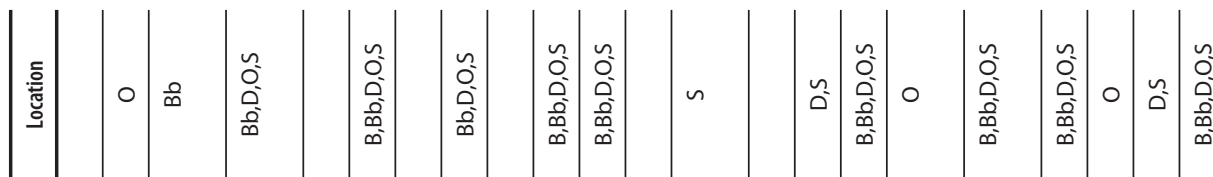

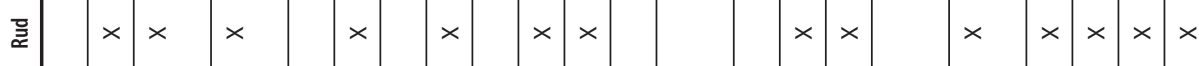

혼

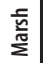

$\times \quad \stackrel{x}{\stackrel{x}{x}} \underset{x}{\stackrel{x}{x}}$

$\stackrel{\stackrel{\sim}{x}}{\stackrel{\sim}{x}} \stackrel{\stackrel{x}{x}}{x}$

蒿

离

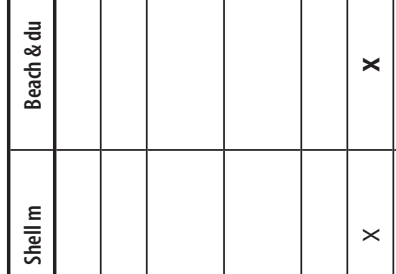

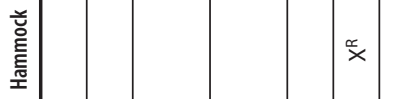

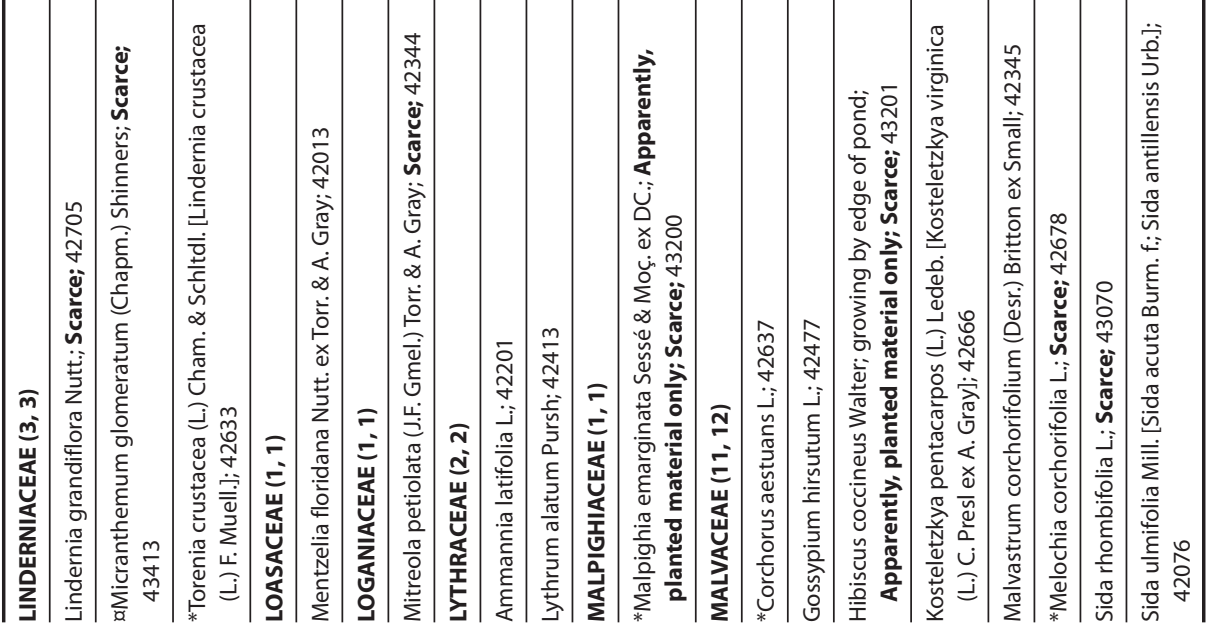




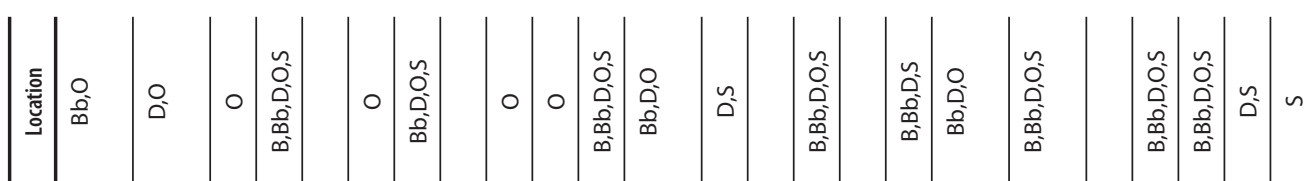

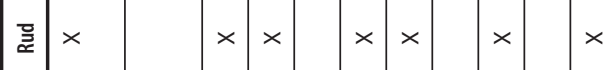

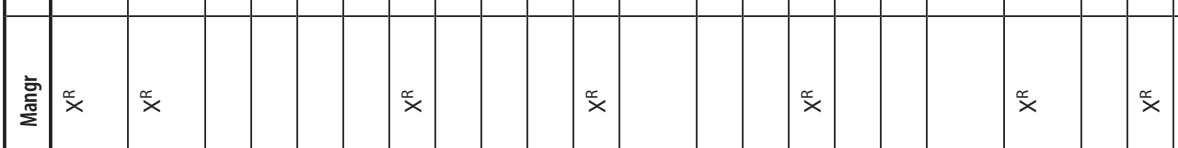

高

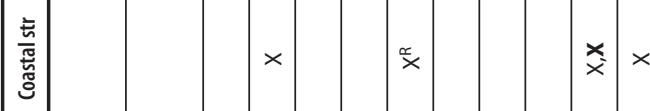

$\times \quad \underset{x}{\stackrel{x}{x}} \quad \stackrel{x}{x} \stackrel{\propto}{x}$

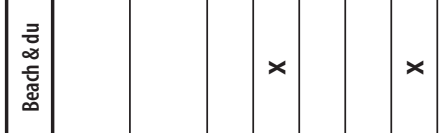

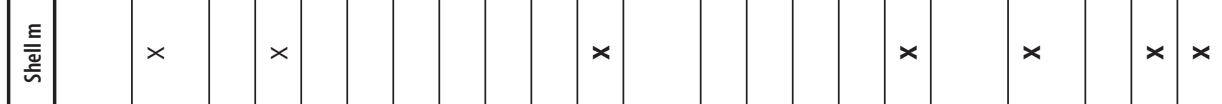

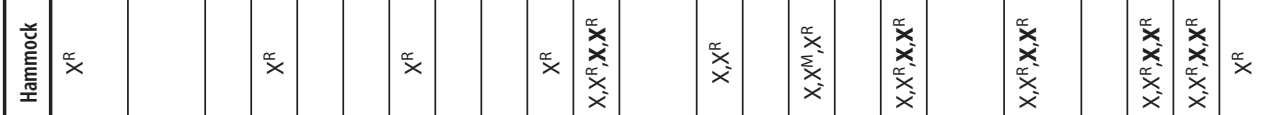

\begin{tabular}{|c|c|c|c|c|c|c|c|c|c|c|c|c|c|c|c|c|c|c|c|c|c|c|}
\hline 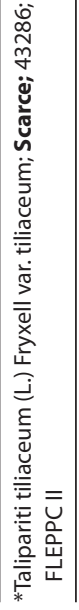 & 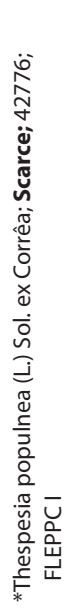 & 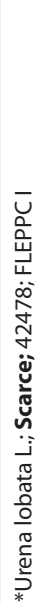 & 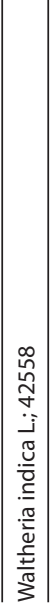 & 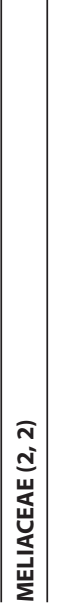 & 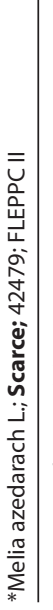 & 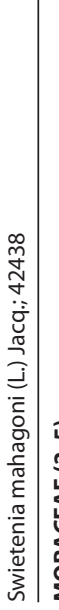 & 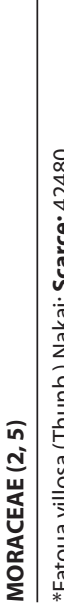 & 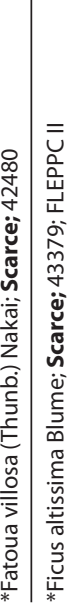 & 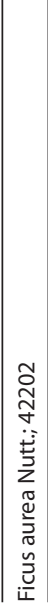 & 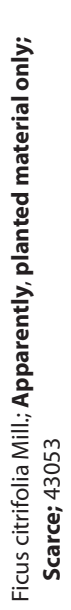 & 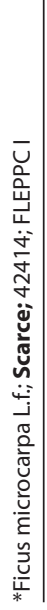 & 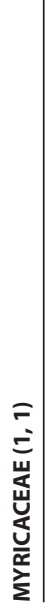 & 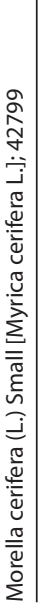 & 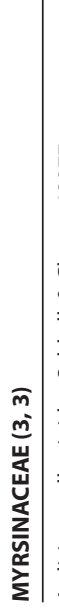 & 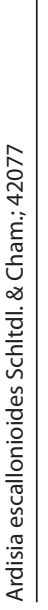 & 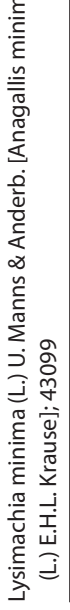 & 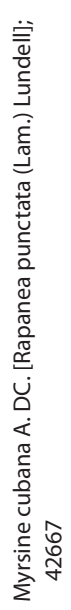 & 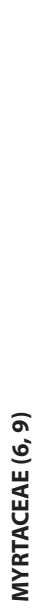 & 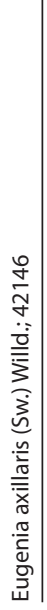 & 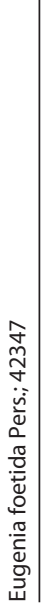 & 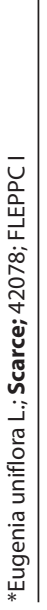 & 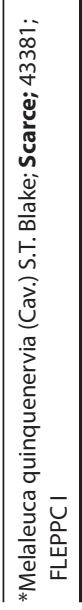 \\
\hline
\end{tabular}




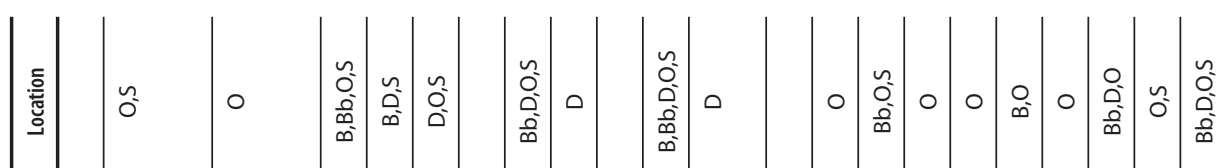

롤

$\times \times \quad \times$

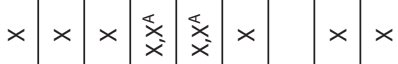

高

$\stackrel{\sim}{x}$

$\frac{\sqrt[5]{\frac{5}{5}}}{2}$

望

$\underset{\times}{\times}$

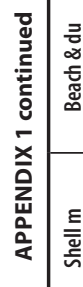

$\underset{x}{x} \quad \begin{aligned} & x \\ & x \\ & \dot{x}\end{aligned}$

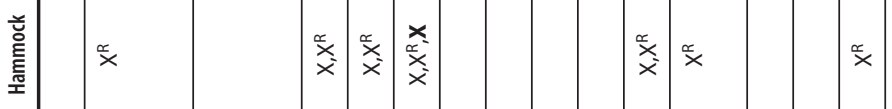

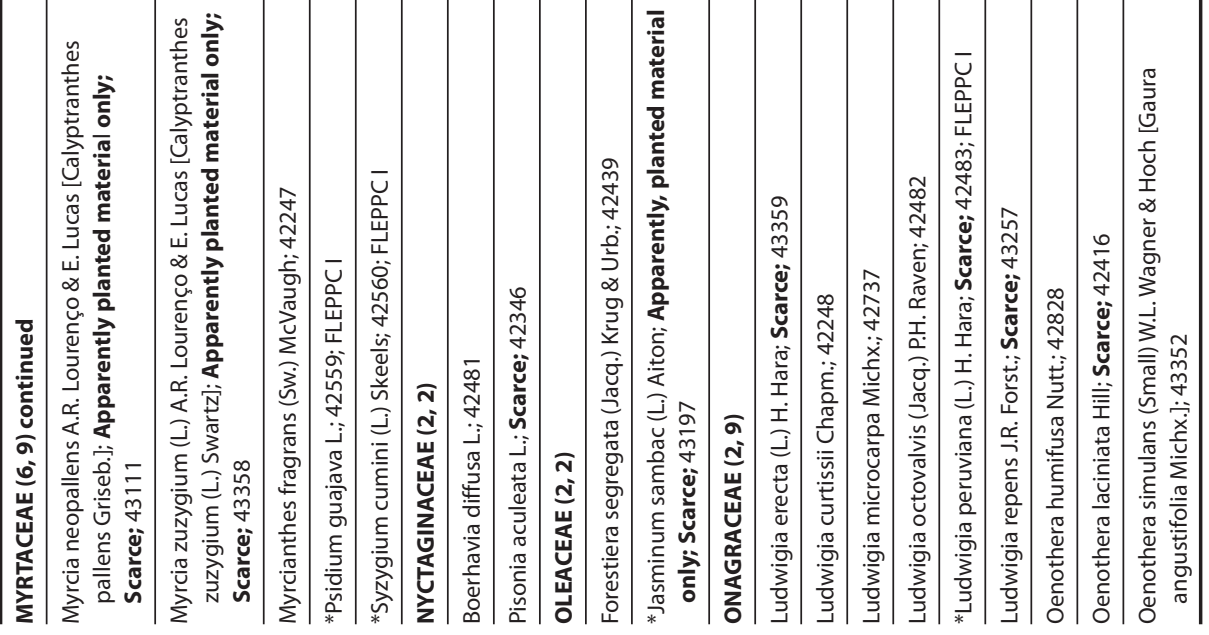




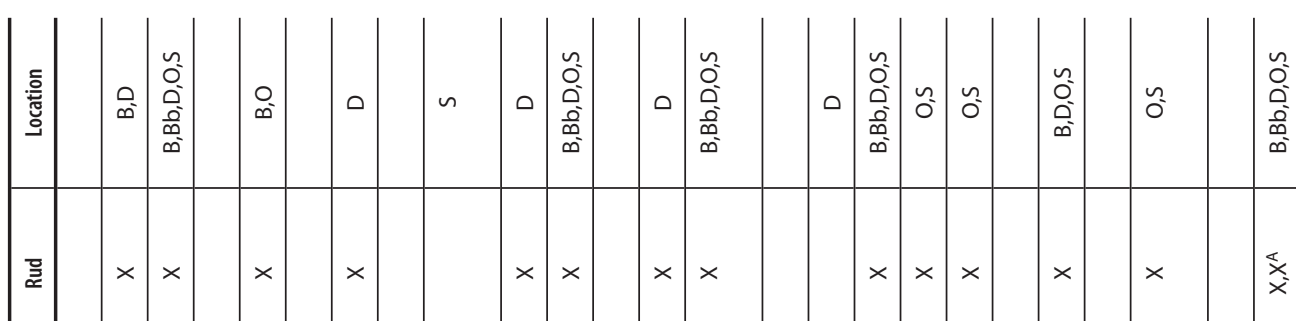

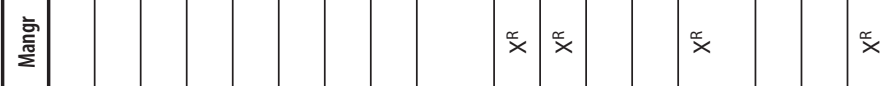

产

$\underset{\substack { x \\ \begin{subarray}{c}{x \\ x{ x \\ \begin{subarray} { c } { x \\ x } } \\{x}\end{subarray}}{x}$

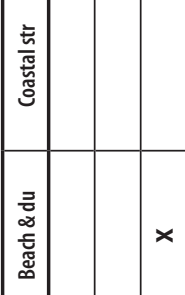

音

$\times \quad \times \underset{x}{\stackrel{x}{x}}$

흘

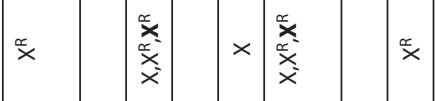

$\stackrel{\frac{x}{x}}{x}$

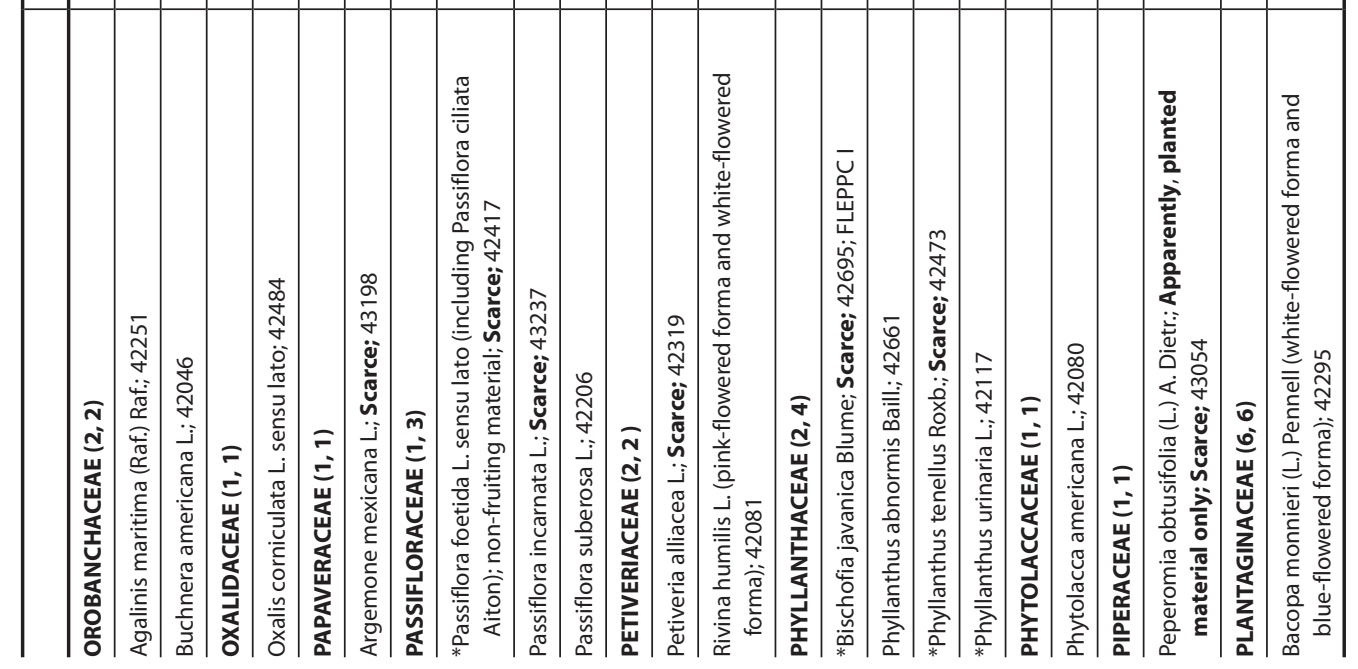




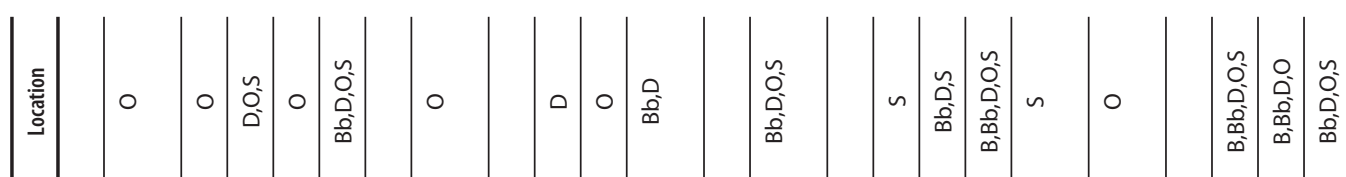

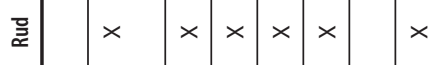

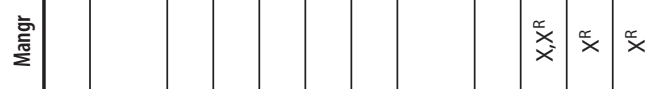

$\frac{\sqrt[5]{\frac{5}{c}}}{\Sigma}$

$\times \times$

竞

$\times \quad \quad \underset{x}{\underset{x}{x}} \quad \quad \quad \underset{x}{\underset{x}{x}} \times \underset{x}{\underset{x}{x}}$

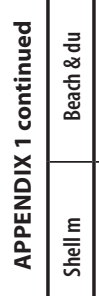

흘

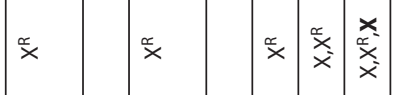

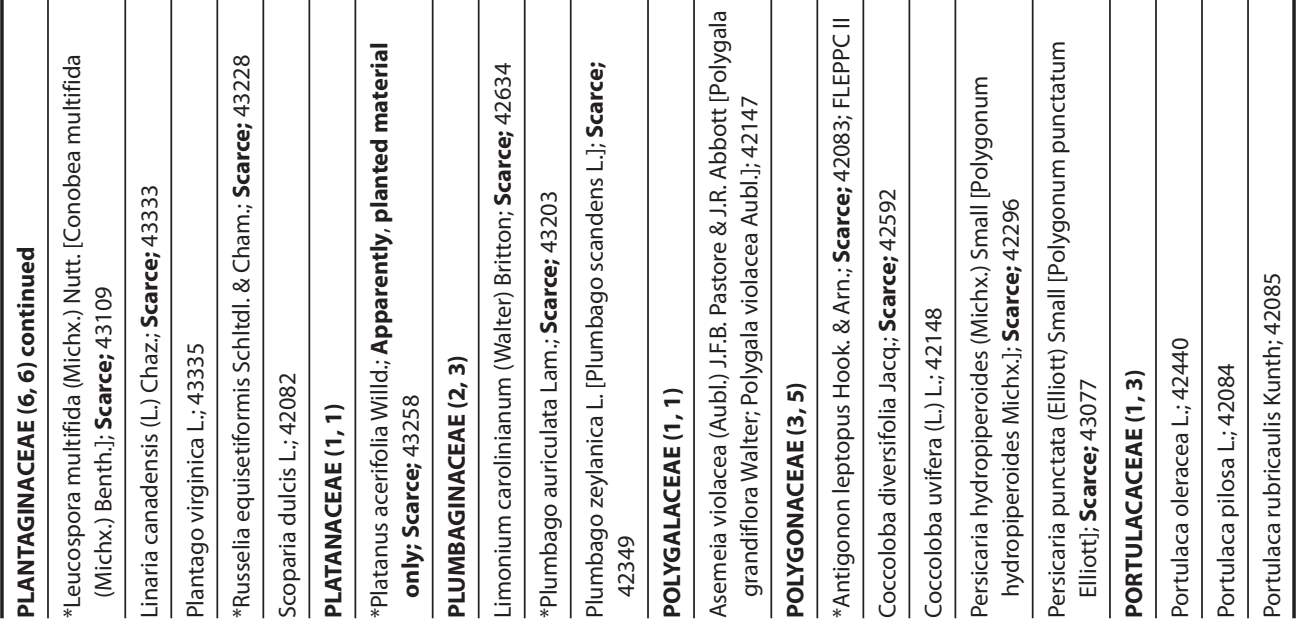




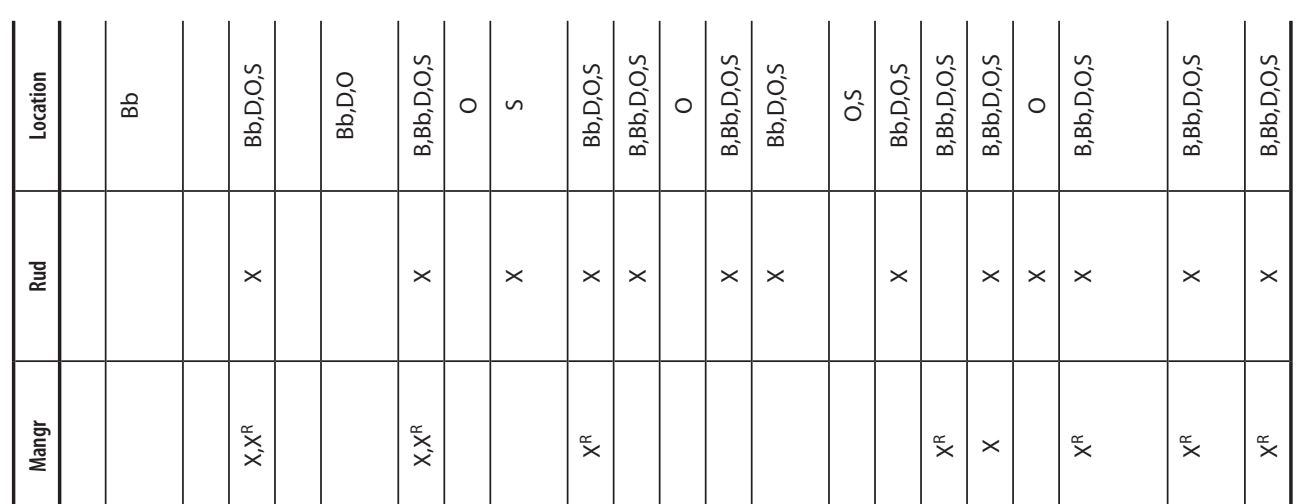

$\frac{\frac{5}{\frac{5}{m}}}{\frac{5}{2}}$

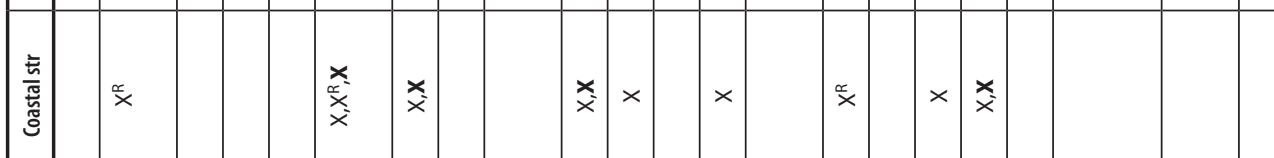

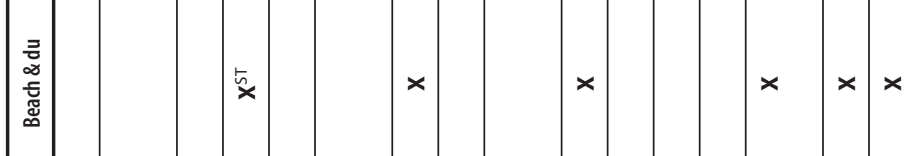

\begin{tabular}{|l|l|l|l|}
$\underline{\underline{E}}$ \\
$\underline{\underline{\omega}}$
\end{tabular}

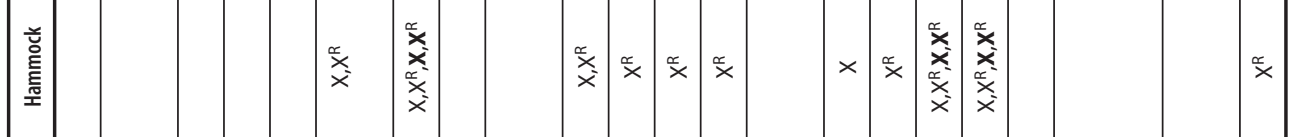

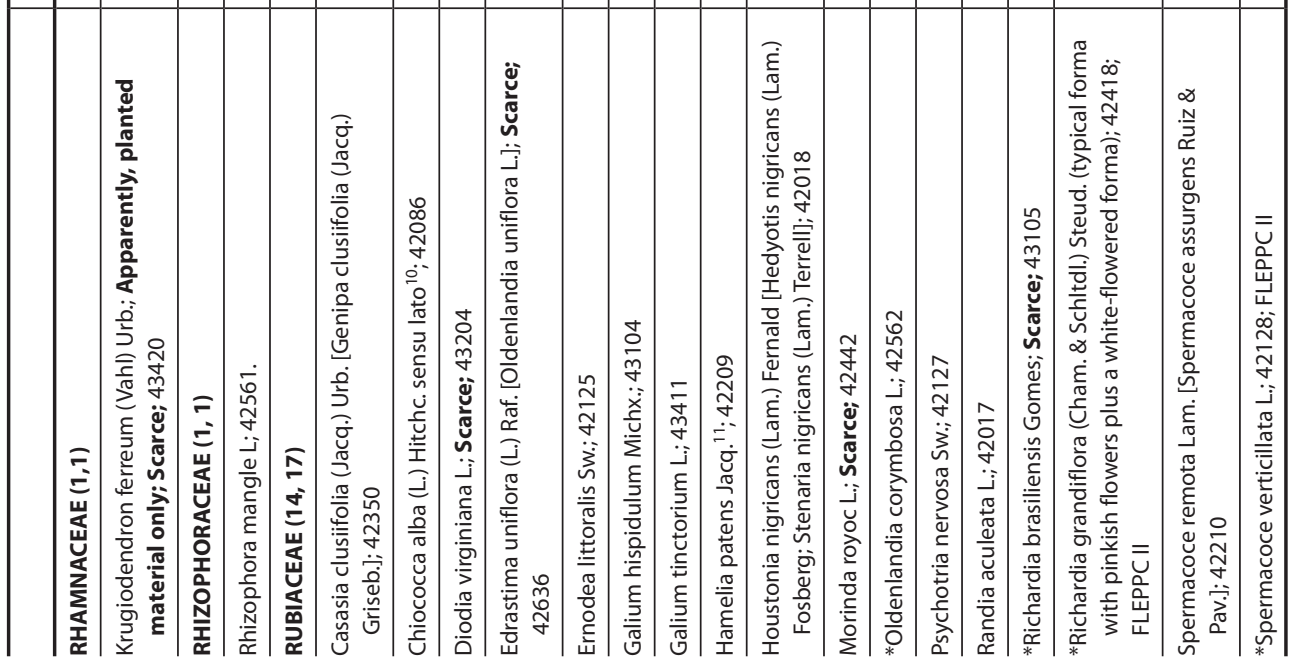




\begin{tabular}{|c|c|c|c|c|c|c|c|c|c|c|c|c|c|c|c|c|c|}
\hline '大. & $\sim$ & 0 & $\infty$ & 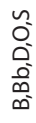 & $\begin{array}{l}\simeq \\
\tilde{0} \\
0 \\
0 \\
0 \\
0 \\
\infty\end{array}$ & 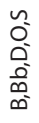 & 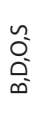 & $\tilde{a}$ & $\begin{array}{l}\tilde{0} \\
0 \\
0 \\
\frac{0}{\infty}\end{array}$ & $\tilde{a}$ & $n$ & 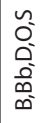 & 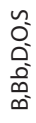 & $\begin{array}{l}\tilde{0} \\
0 \\
0 \\
0 \\
0 \\
0 \\
\infty \\
0\end{array}$ & $\begin{array}{l}n \\
0 \\
0 \\
0 \\
0 \\
0\end{array}$ & 0 & 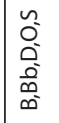 \\
\hline בु & & & $\times$ & $\times$ & $\times$ & $\times$ & $\times$ & $\times$ & & $\times$ & & $\times$ & & $\times$ & & $\times$ & $\times$ \\
\hline $\begin{array}{l}\text { ㅎ․ } \\
\text { 空 }\end{array}$ & & & & $\stackrel{x}{x}$ & $\times$ & $\stackrel{\infty}{x}$ & & & $\stackrel{\alpha}{x}$ & & & $\stackrel{\infty}{x}$ & 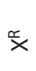 & & & & 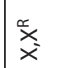 \\
\hline $\begin{array}{l}\frac{\bar{n}}{\underline{n}} \\
\sum\end{array}$ & & & & & $x$ & $\underset{x}{\stackrel{x}{x}}$ & $\times$ & & & & & $\stackrel{\infty}{x}$ & & $\stackrel{\alpha}{x}$ & & & $\underset{x}{x}$ \\
\hline & & & & $x$ & & & & & & & & $\stackrel{x}{x}$ & $\stackrel{x}{x}$ & & $\stackrel{\sim}{x}$ & & \\
\hline
\end{tabular}
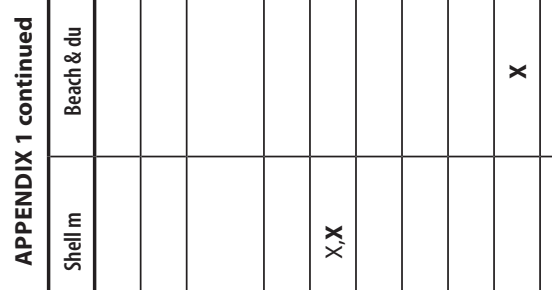

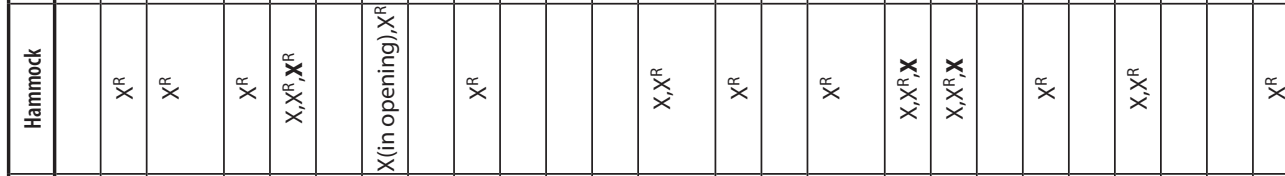

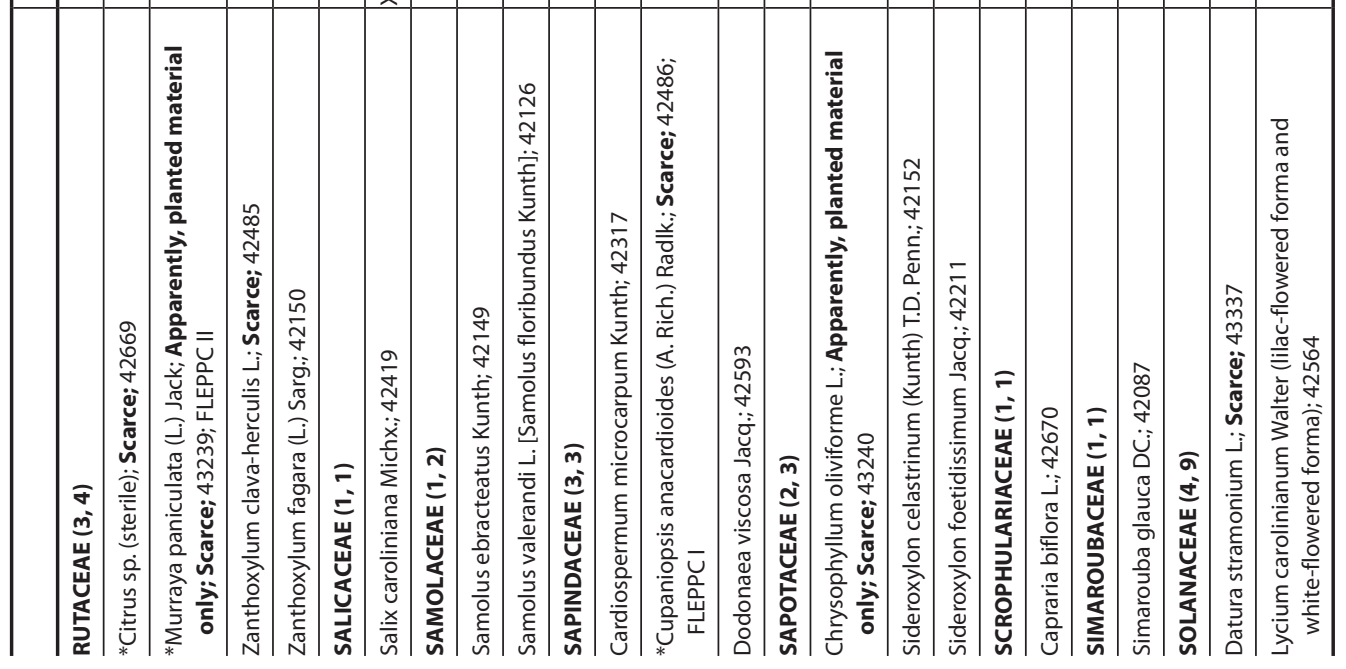




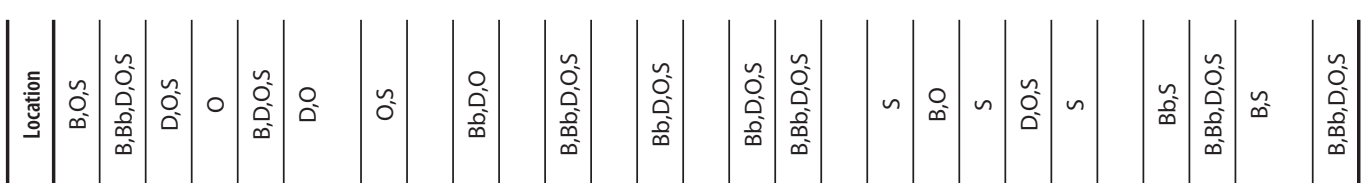

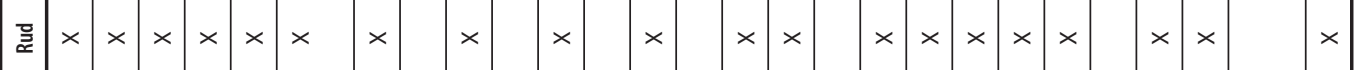

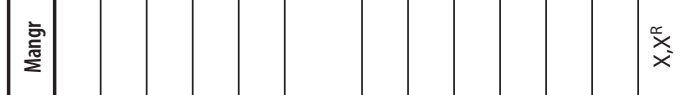

$\sqrt{1 \times 1 \times}$

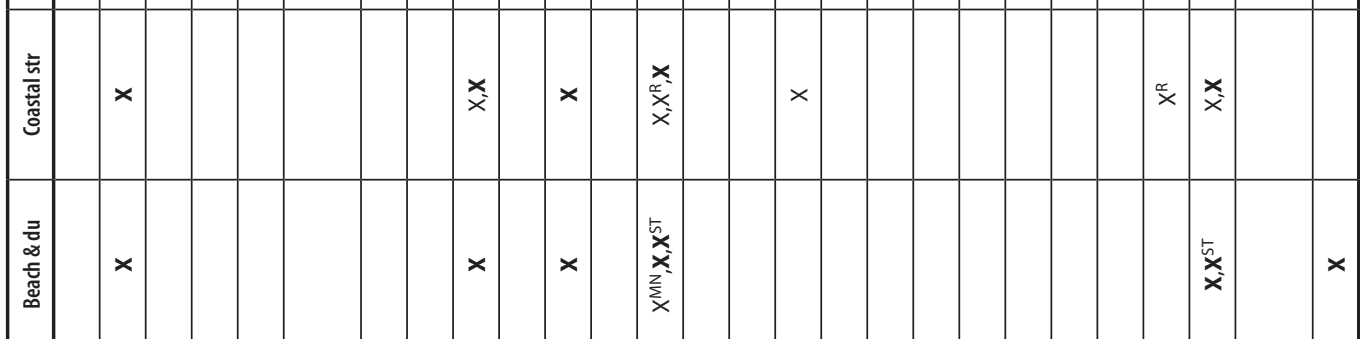

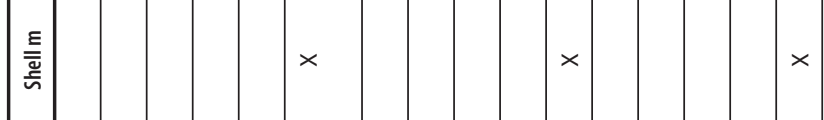

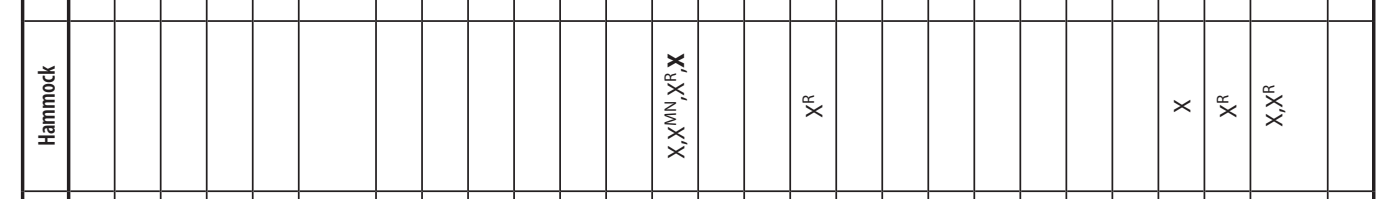

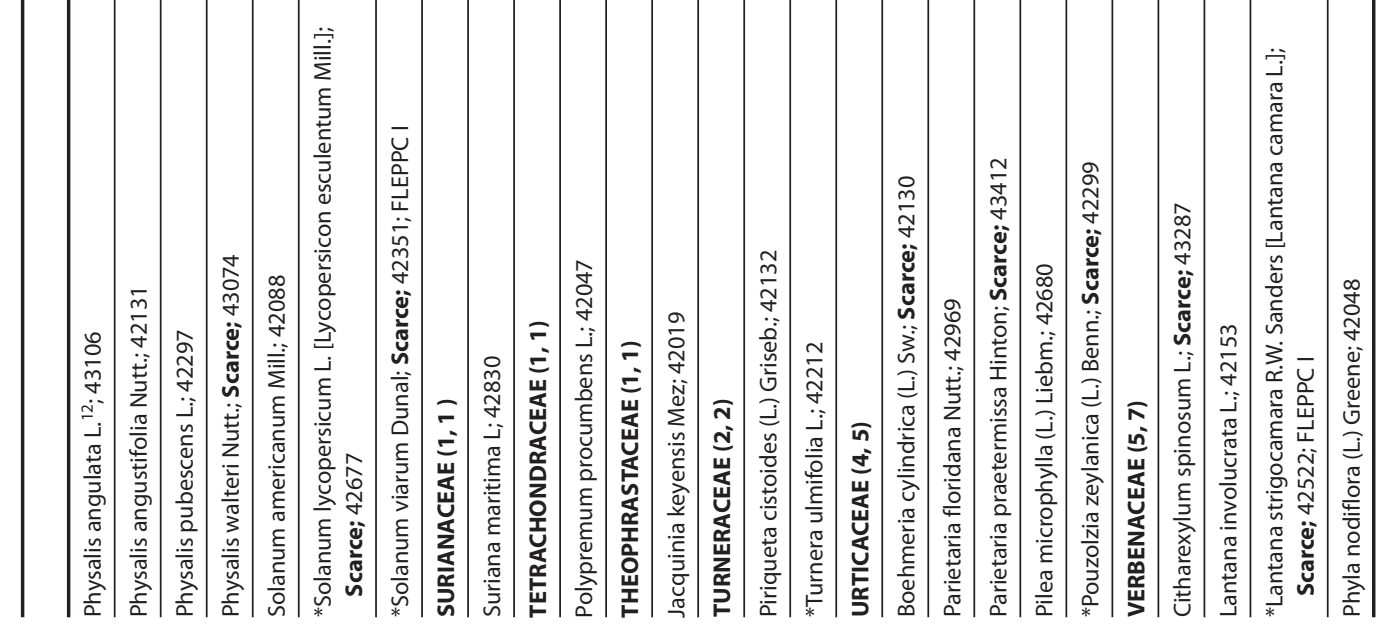




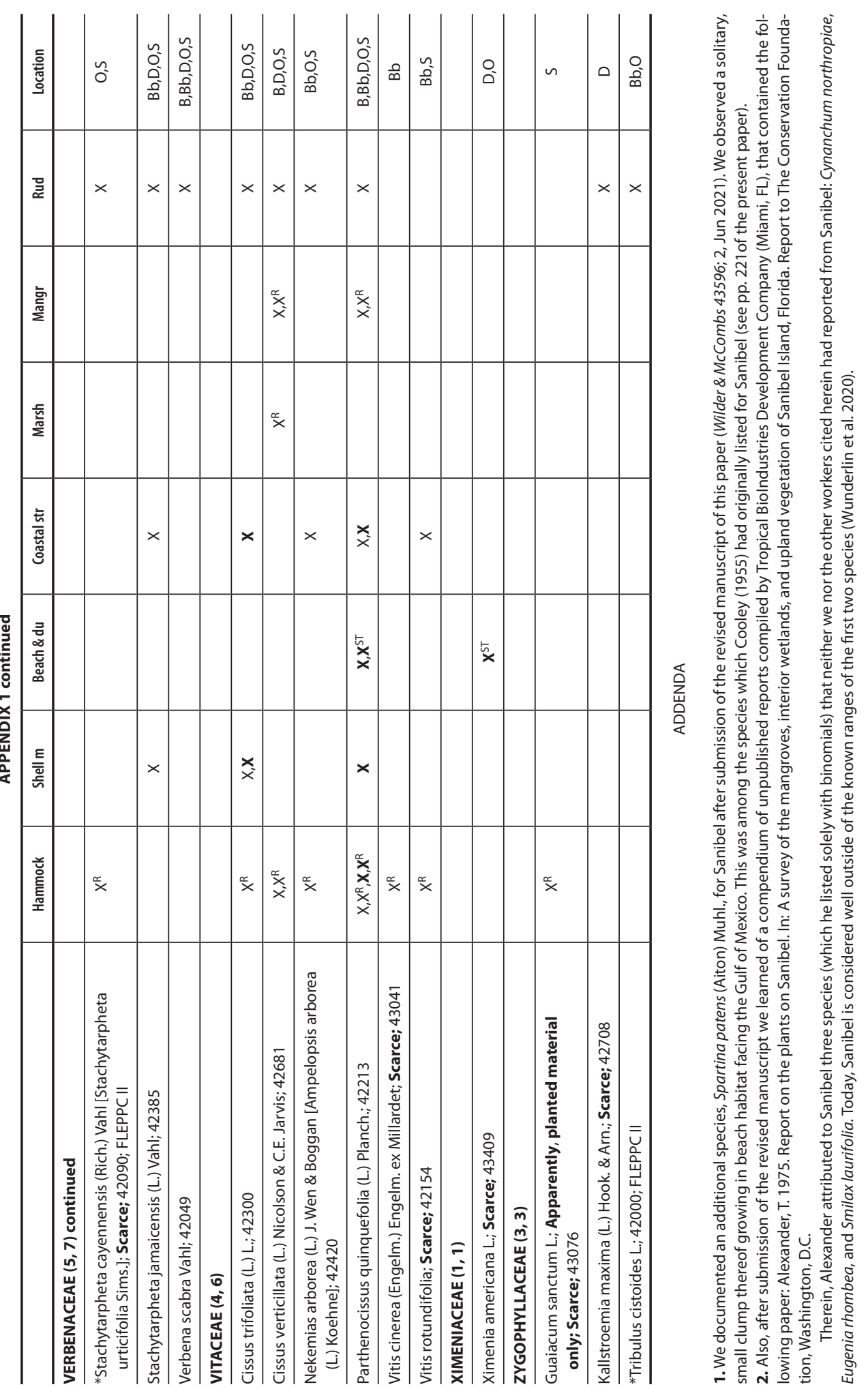




\section{APPENDIX 2}

Infrageneric taxa reported for Sanibel Island by Wunderlin et al (1980), Herwitz and Wunderlin (1990), Bradley (2002), and Stalter and Lamont (2021), collectively, but not listed in this paper or by Cooley (1955). Names preceded by an asterisk are of taxa not native to Florida (based on Wunderlin et al. 2020).

Acrostichum aureum

Agalinis fasciculata

*Agave americana

*Ageratum houstonianum

*Allamanda cathartica

Amaranthus cannabinus

Amaranthus floridanus

Amorpha fruticosa

Amphicarpum muehlenbergianum

*Araucaria heterophylla

Aristida purpurascens var. tenuispica

Asplenium abscissum

*Bambusa vulgaris

*Bauhinia variegata ${ }^{1}$

Bolboschoenus robustus

*Bougainvillea glabra

*Bouteloua dimorpha

*Breynia disticha

*Caesalpinia pulcherrima

*Calliandra haematocephala

*Cantinoa americana

Capsicum annuum var. glabriusculum

*Cardamine hirsuta

Carex albolutescens

Celtis iguanaea

Cephalanthus occidentalis

Chamaecrista fasciculata

*Citrus xaurantiifolia ${ }^{2}$

*Citrus japonica (Fortunella margarita) ${ }^{3}$

Crocanthemum corymbosum

${ }^{*}$ Crotalaria retusa

Croton linearis

*Cyclospermum leptophyllum

Cyperus neotropicalis

Dalea feayi

Desmodium marilandicum

*Desmodium scorpiurus

Dichanthelium dichotomum

Dichanthelium portoricense

Dichanthelium strigosum var. glabrescens

*Digitaria longiflora

Distichlis spicata

*Drymaria cordata

*Duranta erecta

*Echinochloa colona

Echinochloa paludigena
Eriochloa michauxii

Eugenia confusa

Euphorbia inundata

Euphorbia tithymaloides subsp. smallii

Euthamia caroliniana

Evolvulus sericeus

Fimbristylis autumnalis

Fuirena breviseta

Fuirena scirpoidea

*Furcraea foetida var. medio-picta

Geranium carolinianum

*Gomphrena serrata

Gratiola virginiana

Habenaria floribunda

Helianthus debilis subsp. vestitus

Hexalectris spicata

Hexasepalum teres

*Hibiscus rosa-sinensis var. schizopetalus

Hieracium gronovii

Hypoxis juncea

*Ipomoea hederacea

* Justicia brandegeeana

*Kalanchoe fedtschenkoi

Lactuca graminifolia

Lechea sessiliflora

Lemna obscura

Linum medium

Lonicera sempervirens

Ludwigia palustris

Malvastrum americanum

*Manilkara zapota

Mecardonia acuminata subsp. peninsularis

Melochia spicata

*Mollugo verticillata

*Morus alba

Najas marina

Nymphaea mexicana

Packera glabella

*Pandanus utilis ${ }^{4}$

Paspalidium chapmanii

Paspalum blodgettii

Paspalum boscianum

Persicaria setacea

*Phoenix loureiroi ${ }^{5}$
*Phyllanthus amarus

Pilea herniarioides

Pinus palustris

*Polyscias paniculata

Pseudognaphalium obtusifolium

*Ptychosperma elegans

Pyrrhopappus carolinianus

Rhynchosia difformis

Rhynchosia reniformis

Rhynchospora grayi

Rudbeckia hirta

*Rumex pulcher

Rumex verticillatus

Ruppia maritima

Sabatia campanulata ${ }^{6}$

Saccharum giganteum

Sagittaria graminea

Schizachyrium sanguineum

Scleria reticularis

*Sesamum indicum

Sesbania vesicaria

Setaria corrugata

* Setaria pumila

Solanum chenopodioides

Solidago gigantea

Solidago stricta

*Sorghum bicolor

Spartina alterniflora

Spiranthes vernalis

Steinchisma hians

Symphyotrichum dumosum

Symphyotrichum simmondsii

Thelypteris interrupta

Thelypteris palustris var. pubescens

Trianthema portulacastrum

*Tribulus terrestris

Triglochin striata

Typha latifolia

*Urochloa ramosa

Vachellia farnesiana var. pinetorum

Varronia globosa

Vitis aestivalis

Woodwardia virginica

Xyris elliottii

1,2,3,4,5 In this paper we report Bauhinia sp., Citrus sp., Citrus sp., Pandanus sp., and Phoenix sp., respectively.

${ }^{6}$ Sabatia campanulata and Sabatia stellaris resemble one another morphologically (Fernald 1950). Wunderlin and Hansen (2011) and Wunderlin et al. (2018) distinguished between them, partly, as follows:"sepals subequaling the petals" (in S. campanulata) and sepals "ca. $3 / 4$ as long as the petals" (in S. stellaris); however, Fernald (1950) characterized the calyx lobes of S. stellaris as "usually shorter than the corolla" (emphasis ours). On Sanibel we collected certain plants which were clearly from one of those two species, on which the longest sepal(s) of a flower was/were longer than the associated petal(s) (Wilder \& McCombs 43343, 43344, 43345, 43414); we identified those plants as S. stellaris. We did so because $\mathbf{a}$. they lacked a woody caudex, and $\mathbf{b}$. they manifested solitary rather than clustered stems (both features being of S. stellaris but not of S. campanulata [Fernald 1950; Gleason \& Cronquist 1991]). The listing of S. campanulata in Appendix 2 is based on Bradley's (2002) (apparently undocumented) report of this species for Sanibel and it places the species considerably south of its known range in Florida (Wunderlin et al 2020). We speculate that Bradley's (2002) report reflects a misidentification of S. stellaris, based on reliance on relative sepal lengths as a diagnostic character. 
APPENDIX 3

\section{Origin of the name Sanibel}

"Sanibel" is a corruption of the Spanish name for a harbor, Puerto de S. Nivel ("South Plane Harbor"), which existed at the southeastern tip of Sanibel Island. The first map bearing that name dates from 1765. Another map, of 1768, has the name "Puerto de S. Nibel" ( $\underline{b}$ and $\underline{v}$ being interchangeable). A later map of the same year indicates "Puerto de Sn. Nibel" "Port of Saint Nibel" [that name representing in this case a mis-construal of the letter $\underline{S}$ as "Saint"]). Bernard Romans, in 1774, utilized the names "Sanybel" and "San Ybell." Finally, in 1775, another map indicated "Sanibel"—the name used today (Dormer 1987).

\section{DEDICATION AND ACKNOWLEDGMENTS}

We dedicate this paper to those environmentally concerned individuals who struggled—against formidable opposition and with considerable success - to preserve and restore Sanibel's natural environments.

We express deep appreciation to Donna McGinnis (the Director of the Naples Botanical Garden [NBG]) and to NBG for providing laboratory space for the present study and for housing the SWF Herbarium. Too, we thank these additional staff members/associates of NBG for their diverse contributions: Karin Balsbaugh, Gary Boivin, Mike Brewer, Gavin Cooke, Esther Chiddister, James Connally, Mary Dominguez, Eric Foht, William Lee, Anne Li, Ralph Klebosis, Reynaldo Monserrat, Kim Olson, Barbara Pace, Karen Pattison, Bill Pattison, Lori Piper, Jean Roche, Dede Schoenberg, Marco Stavole, and Eileen Watkins. We extend especial gratitude to Jeremy Conrad of the Ding Darling National Wildlife Refuge (DDNWR), to the City of Sanibel (particularly, to James Evans and his staff of the Sanibel Natural Resources Dept.), and to Chris Lechowicz of the Sanibel Captiva Conservation Foundation (SCCF) for permission to undertake research on properties managed by DDNWR, the City of Sanibel, and SCCF, respectively. We also thank the Sanibel Historical Museum and Village as well as the following individuals for their assistance: Austin Bell, Ruth Brooks, Jenny Evans, Dustin Lucas, William Marquardt, Randy Mears, George Newman, Veronica Runge, Richard Stalter, Victor Young, and Rebecca Wilder. Too, George Wilder expresses gratitude to Dick Workman (deceased), who served as a former administrative director of SCCF and who introduced him to Sanibel's flora ca. 17 years ago. As well, we thank Alan Franck and an anonymous reviewer for their careful reviews of the manuscript of this paper.

\section{REFERENCES}

Allen, C.M. \& D.W. Hall. 2003. Paspalum L. In: Flora of North America Editorial Committee, eds., Flora of North America north of Mexico. Vol. 25. Oxford University Press, New York, U.S.A.

AnHolt, B. 2004. Sanibel-Captiva Conservation Foundation: a natural course. Sanibel-Captiva Conservation Foundation, Sanibel, Florida, U.S.A.

ATtAWAY, JoHn A. 1999. Hurricanes and Florida agriculture. Florida Science Source, Inc., Lake Alfred, Florida, U.S.A.

Austin, D.F. 2004. Florida ethnobotany. CRC Press, Boca Raton, Florida, U.S.A.

BAlLEY, F. 2013. My 92 years on Sanibel. CreateSpace Independent Publishing Platform, Scotts Valley, California, U.S.A.

BARNES, JAY. 2007. Florida's hurricane history. 2nd ed. University of North Carolina Press, Chapel Hill, North Carolina, U.S.A.

BradLey, K.A. 2002. Vegetation analysis of preserves owned by the Sanibel-Captiva Conservation Foundation. Unpublished report submitted to the Sanibel-Captiva Conservation Foundation, Sanibel Island, Florida, U.S.A.

CHAFIN, L.G. 2000. Field guide to the rare plants of Florida. Florida Natural Areas Inventory, Tallahassee, Florida, U.S.A.

CitY of SANIBEL. 2021a. Other invasive exotic vegetation, City-listed invasive exotic vegetation. https://www.mysanibel. com/Departments/Natural-Resources/Vegetation-Information.

CitY of SANIBEL. 2021b. Tropical Storm / Hurricane including Hurricane (Evacuation) Reentry Passes, Sanibel Tropical Storm and Hurricane History. https://www.mysanibel.com/Departments/Police-including-Emergency-Management/ Emergency-Management/Tropical-Storm-Hurricane-including-Hurricane-Evacuation-Reentry-Passes/ Hurricane-Reentry-Pass-Program.

CLARK, J. 1976. The Sanibel report. Formulation of a comprehensive plan based on natural systems. The Conservation Foundation, Washington, D.C., U.S.A.

Cooley, G.R. 1955. The vegetation of Sanibel Island Lee County, Florida. Rhodora 57(682): 1-31.

CoRreLL, D.S. \& M.C. Johnston. 1970. Manual of the vascular plants of Texas. Texas Research Foundation, Renner, Texas, U.S.A.

dDNRC (J.N. Ding Darling Refuge Complex \& U.S. Fish and Wildife Service). 2010. J.N. “Ding” Darling National Wildlife Refuge 
Comprehensive Conservation Plan. U.S. Department of the Interior Fish and Wildlife Service, Southeast Region. https://ecos.fws.gov/ServCat/DownloadFile/8237.

Dormer, E.M. 1987. The sea shell islands: a history of Sanibel and Captiva. Revised ed. Rose Printing Co., Tallahassee, Florida, U.S.A.

fDACS (Florida Department of Agriculture and Consumer Services). 2020. Endangered, threatened and commercially exploited plants of Florida. https://www.fdacs.gov/Divisions-Offices/Plant-Industry/Bureaus-and-Services/ Entomology-Nematology-Plant-Pathology/Botany/Florida-s-Endangered-Plants. Florida Department of Agriculture and Consumer Services, Tallahassee, Florida, U.S.A.

fDACS (Florida Department of Agriculture and Consumer Services). 2021. Florida Champion Trees Register. https://www. fdacs.gov/Forest-Wildfire/Our-Forests/Florida-Champion-Trees. Florida Department of Agriculture and Consumer Services, Tallahassee, Florida, U.S.A.

FERNALD, M.L. 1950. Gray's manual of botany. $8^{\text {th }}$ (centennial) ed. American Book Co., New York, U.S.A.

FLEPPC (FLORIDA EXOTIC PEST PLANT CounCIL). 2019. Florida EPPC's 2019 list of invasive plant species. www.fleppc.org/list/list. htm. Center for Invasive Species and Ecosystem Health, University of Georgia, Tifton, Georgia, U.S.A.

Franck, A.R. 2017. Notes on trifoliolate species of Galactia (Fabaceae) in Florida. Phytologia. 99(2):139-185.

Franck, A.R., G.D. GANN, J. SADLE, \& A. FARID. 2021. Sharpening plant taxonomy in South Florida: Baccharis and Melanthera (Asteraceae), Borreria and Chiococca (Rubiaceae), and Lantana (Verbenaceae). Phytologia. Submitted.

GanN, G.D., K.A. Bradley, \& S.W. WoodmanseE. 2002. Rare plants of South Florida: Their history, conservation, and restoration. The Institute for Regional Conservation, Miami, Florida, U.S.A.

GleAson, H.A. \& A. CRONQUist. 1991. Manual of vascular plants of northeastern United States and adjacent Canada. 2nd ed. The New York Botanical Garden, Bronx, New York, U.S.A.

HALL, D.W. 2019. Grasses of Florida. University Press of Florida, Gainesville, Florida. U.S.A.

HeNDERSON, W.G. JR. 1984. Soil survey of Lee County, Florida. U.S. Dept. Agriculture Soil Conservation Service.

Henrickson, J. 2010. Comments on a revision of Celtis subgenus Mertensia (Celtidaceae) and the recognition of Celtis pallida. J. Bot. Res. Inst. Texas 4(1):287-293.

HERWITZ, S.R. \& R.P. WUNDERLIN. 1990. Vascular plant species diversity on two barrier islands in southwest Florida. J. Coastal Res. 6(2):311-322.

IRC (Institute for Regional Conservation). 2021. Galactia parvifolia A. Rich. In: Floristic inventory of the Florida Keys database online. https://www.regionalconservation.org/ircs/database/plants/PlantPageFK.asp?TXCODE=Galaparv. Delray Beach, Florida, U.S.A.

LeBufF, C., \& C. LECHOWICz. 2013. Amphibians \& reptiles of Sanibel \& Captiva Islands, Florida. Amber Publishing, Fort Myers, Florida, U.S.A.

LECHOWICZ, C. 2020. When natives become invasive: battle of the buttonwood (Conocarpus erectus). CISMA Invasive Species Symposium (unpublished presentation). Fort Myers, Florida, U.S.A.

LodGE, T.E. 2010. The Everglades handbook: understanding the ecosystem. 3rd ed. CRC Press, Boca Raton, Florida, U.S.A. LoNG, R.W. \& O. LAKELA. 1976. A flora of tropical Florida: a manual of the seed plants and ferns of southern peninsular Florida. Banyan Books, Miami, Florida, U.S.A.

Peterson, P.M. 2003. Eragrostis Wolf. In: Flora of North America Editorial Committee, eds. Flora of North America north of Mexico. Vol. 25. Oxford University Press, New York, U.S.A.

REPKo, M. 2010. A brief history of Sanibel Island. ECity Publishing, Everglades City, Florida, U.S.A.

Sanibel \& Captiva Islands Chamber of Commerce. 2019. The islands of Sanibel-Captiva: naturally, you'll love it here. Sanibel Chamber of Commerce, Sanibel, Florida, U.S.A.

SemplE, J.C. \& R.E. Соок. 2006. Solidago Linnaeus. In: Flora of North America Editorial Committee, eds. Flora of North America north of Mexico. Vol. 20. Oxford University Press, New York, U.S.A.

SERNEC (Southeastern Regional Network of Expertise and Collections). 2020. https://sernecportal.org/portal/index.php. Southeastern regional network of expertise and collections, Boone, North Carolina, U.S.A.

Stalter, R. \& E.E. Lamont. 2021. Vascular flora of J.N. “Ding” Darling National Wildlife Refuge, Sanibel Island, Florida, U.S.A. Bot. Res. Inst. Texas, 15(1):261-270.

TebeAu, C.W. 1966. Florida's last frontier. The history of Collier County. University of Miami Press, Miami, Florida, U.S.A. Tebeau, C.W. 1968. Man in the Everglades. 2000 years of human history in the Everglades National Park. 2nd revised ed. University of Miami Press, Coral Gables, Florida, U.S.A.

The Florida State University Biology Department. 2021. The Florida State University Biology Department Robert K. Godfrey Herbarium. https://herbarium.bio.fsu.edu/database.php/ . Florida State University, Tallahassee, Florida, U.S.A. 
University of Florida Herbarium Collections Catalog. 2021. https://www.floridamuseum.ufl.edu/herbarium/cat/ . Florida Museum of Natural History, Gainesville, Florida, U.S.A.

uSDA (USDA, Natural Resources Conservation Service). 2020. The PLANTS Database: Wetland Indicator Status Search. http:// plants.usda.gov. National Plant Data Team, Greensboro, North Carolina, USA.

VERI, R.R. \& L. WARNER. 1975. Interior wetlands water quality management. The Conservation Foundation, Inc., Washington D.C., U.S.A.

Virtual Herbarium. 2021. Virtual Herbarium. http://www.virtualherbarium.org/. Fairchild Tropical Botanic Garden, Coral Gables, Florida, U.S.A.

WiLDER, G.J. \& M.R. Mccombs. 2006. New and significant records of vascular plants for Florida and for Collier County and Lee County, Florida. Sida 22:787-799.

WiLDER, G.J. \& B.J. Roche. 2009. A floristic inventory of Marco Island (Collier County), Florida. J. Bot. Res. Inst. Texas 3(2):873-899.

Wilder, G.J., S.V. Sprunt, J.A. Dugesnel, \& S.F. Kolterman. 2014. A floristic inventory of Dagny Johnson Key Largo Hammock Botanical State Park and immediately adjacent lands (Monroe County), Florida, U.S.A. J. Bot. Res. Inst. Texas $8(1): 227-251$.

Wilder, G.J. \& M.J. BARRY. 2012. A floristic inventory of Dismal Key and Fakahatchee Island-two shell mounds situated within the Ten Thousand Islands region in the Gulf of Mexico (Collier County, Florida). J. Bot. Res. Inst. Texas 6(1):259-272.

Wilder, G.J. \& B.L. Thomas. 2016. A floristic inventory of Collier-Seminole State Park and immediately adjacent lands (Collier County), Florida, U.S.A. J. Bot. Res. Inst. Texas 10(1):201-244.

WiLder, G.J. \& J.M. Mccollom. 2018. A floristic inventory of Corkscrew Swamp Sanctuary (Collier County and Lee County), Florida, U.S.A. J. Bot. Res. Inst. Texas 12(1):265-315.

WildeR, G.J., J.M. Mccollom, \& N.J. Bissett. 2019. A floristic inventory of the Holmes Avenue Tract (Highlands Co.), Florida. J. Bot. Res. Inst. Texas 13(2):499-543.

WIPFF, J.K. 2003. Digitaria Haller. In: Flora of North America Editorial Committee, eds. Flora of North America north of Mexico. Vol. 25. Oxford University Press, New York, U.S.A.

WUNDERLIN, R.P., \& B.F. HANSEN. 1985. Native and naturalized vascular plants of Sanibel and Captiva Islands. Sanibel-Captiva Conservation Foundation, Sanibel, Florida, U.S.A.

WunderLin, R.P. \& B.F. HANSEN. 2011. Guide to the vascular plants of Florida, 3rd ed. University Press of Florida, Gainesville, Florida, U.S.A.

WUnderLin, R.P. \& B.F. HANSEn. 2016. Flora of Florida. Vol. III. Dicotyledons, Vitaceae through Urticaceae. University Press of Florida, Gainesville, Florida, U.S.A.

Wunderlin, R.P., D. Richardson, \& B.F. Hansen. 1980. The vascular flora of the J.N. “Ding” Darling National Wildlife Refuge, Lee County, Florida. Unpublished report submitted to the U.S. Fish \& Wildlife Service, Sanibel, Florida.

Wunderlin, R.P., B.F. Hansen, \& A.R. Franck. 2018. Flora of Florida. Vol. V. Dicotyledons, Gisekiaceae through Boraginaceae. University Press of Florida, Gainesville, Florida, U.S.A.

Wunderlin, R.P., B.F. Hansen, \& A.R. Franck. 2019. Flora of Florida. Vol. VI. Dicotyledons, Convolvulaceae through Paulowniaceae. University Press of Florida, Gainesville, Florida, U.S.A.

Wunderlin, R.P., B.F. Hansen, A.R. Franck, \& F.B. Essig. 2020. Atlas of Florida plants. http://florida.plantatlas.usf.edu/. Institute for Systematic Botany, University of South Florida, Tampa, Florida, U.S.A. 